*⿻千日

\title{
Western Gas Sands Project Status Report
}

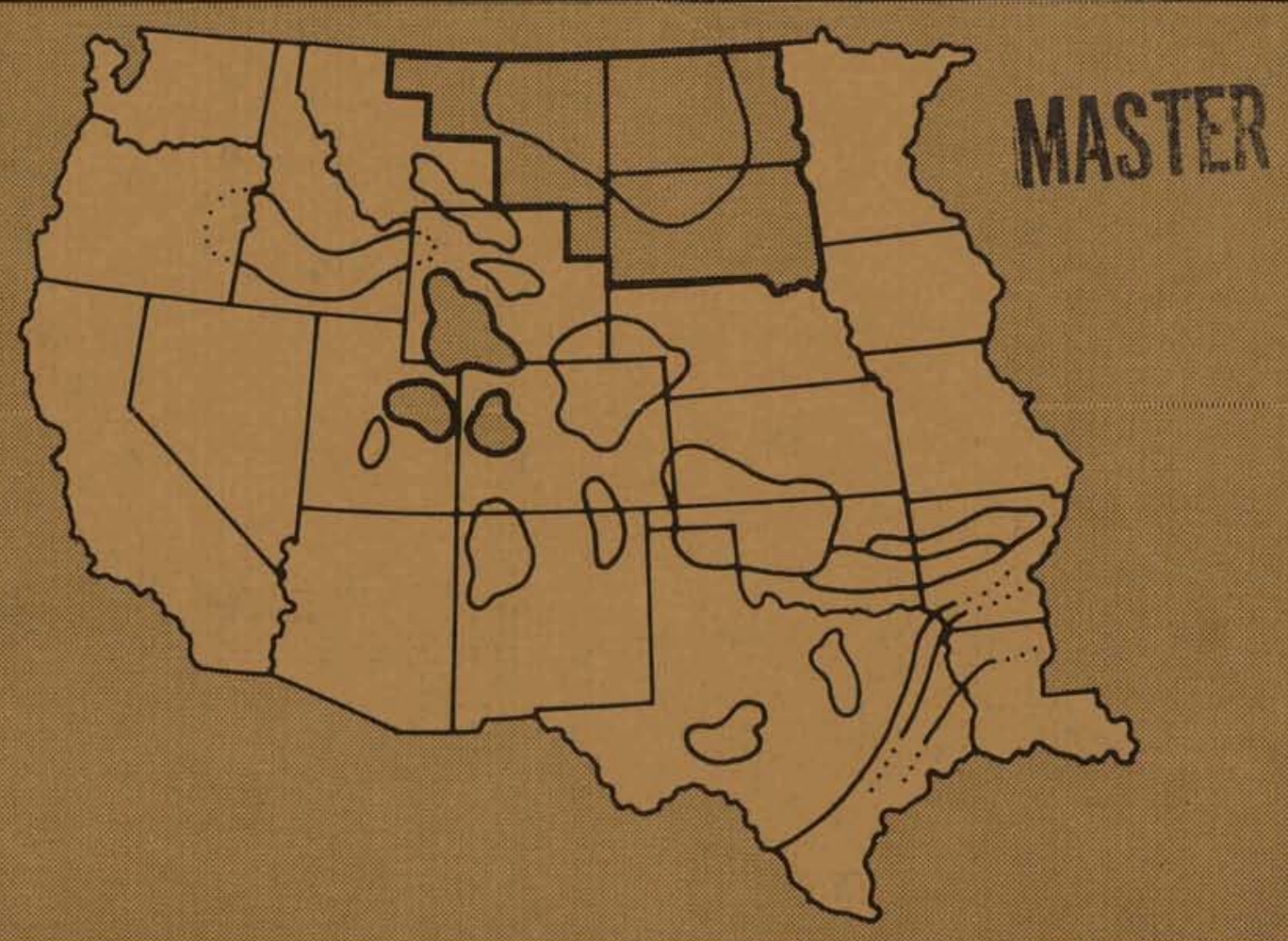

1 December 1979 - 31 December 1979

Prepared for

U.S. Department of Energy

Bartlesville Energy Technology Center

Las Vegas Field Office

Compiled by CER Corporation

Las Vegas, Nevada

Contract DE-AC08-79BC10003

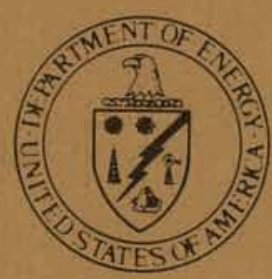




\section{DISCLAIMER}

This report was prepared as an account of work sponsored by an agency of the United States Government. Neither the United States Government nor any agency Thereof, nor any of their employees, makes any warranty, express or implied, or assumes any legal liability or responsibility for the accuracy, completeness, or usefulness of any information, apparatus, product, or process disclosed, or represents that its use would not infringe privately owned rights. Reference herein to any specific commercial product, process, or service by trade name, trademark, manufacturer, or otherwise does not necessarily constitute or imply its endorsement, recommendation, or favoring by the United States Government or any agency thereof. The views and opinions of authors expressed herein do not necessarily state or reflect those of the United States Government or any agency thereof. 


\section{DISCLAIMER}

Portions of this document may be illegible in electronic image products. Images are produced from the best available original document. 
This report was prepared as an account of work sponsored by the United States Government. Neither the United States nor the United States DOE, nor any of their employees, nor any of their contractors, subcontractors, or their employees, makes any warranty, express or implied, or assumes any legal liability or responsibility for the accuracy, completeness, or usefulness of any information, apparatus, product or process disclosed, or represents that its use would not infringe privately owned rights.

Available from the National Technical In formation Service, U. S. Department of Commerce, Springfield, Virginia 22161.

NATIONAL TECHNICAL INFORMATION SERVICE PAPER COPY PRICES EFFECTIVE JANUARY 1, 1979

$\begin{array}{lc}\begin{array}{l}\text { Page } \\ \text { Range }\end{array} & \begin{array}{c}\text { Domestic } \\ \text { Price }\end{array} \\ & \\ 001-025 & \$ 4.00 \\ 026-050 & \$ 4.50 \\ 051-075 & \$ 5.25 \\ 076-100 & \$ 6.00\end{array}$




\section{CONTENTS}

Page

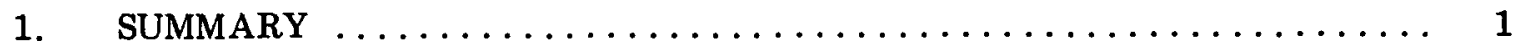

2. PROJECT MANAGEMENT $\ldots \ldots \ldots \ldots \ldots \ldots \ldots \ldots \ldots \ldots \ldots \ldots \ldots \ldots \ldots \ldots$

2.1 Technical Monitoring and Evaluation $\ldots \ldots \ldots \ldots \ldots \ldots \ldots \ldots$

3. RESOURCE ASSESSMENT $\ldots \ldots \ldots \ldots \ldots \ldots \ldots \ldots \ldots \ldots \ldots \ldots \ldots$

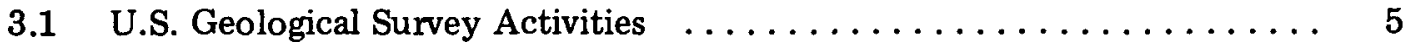

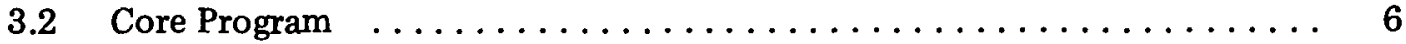

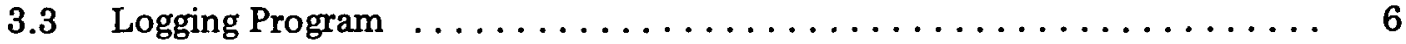

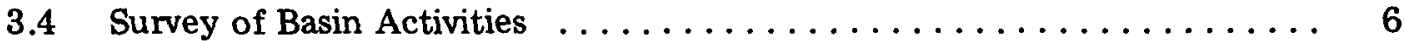

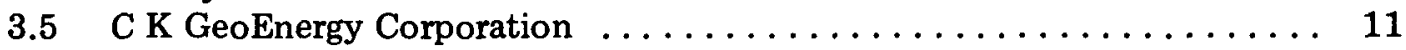

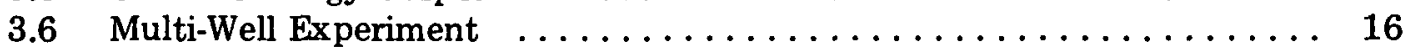

4. RESEARCH AND DEVELOPMENT BY ENERGY TECHNOLOGY CENTERS AND NATIONAL LABORATORIES $\ldots \ldots \ldots \ldots \ldots \ldots \ldots \ldots$

4.1 Bartlesville Energy Technology Center $\ldots \ldots \ldots \ldots \ldots \ldots \ldots \ldots \ldots$

4.2 Gas Research Institute . . . . . . . . . . . . . . . . . 28

4.3 Lawrence Livermore Laboratory $\ldots \ldots \ldots \ldots \ldots \ldots \ldots \ldots \ldots \ldots \ldots$

4.4 Los Alamos Scientific Laboratory ..................... 33

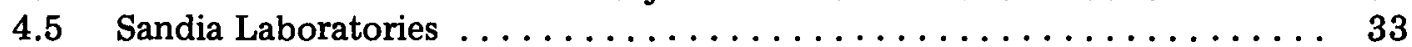

5. FIELD TESTS AND DEMONSTRATIONS $\ldots \ldots \ldots \ldots \ldots \ldots \ldots \ldots \ldots$

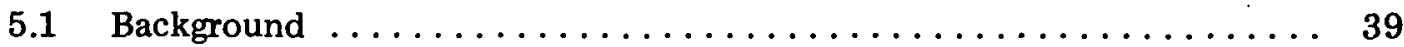

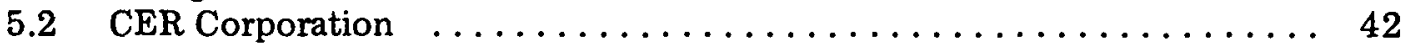

5.3 Colorado Interstate Gas Company $\ldots \ldots \ldots \ldots \ldots \ldots \ldots \ldots \ldots \ldots \ldots . \ldots \ldots$

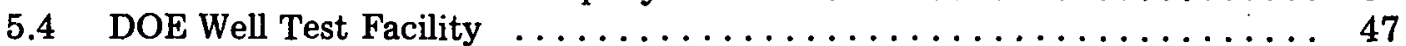

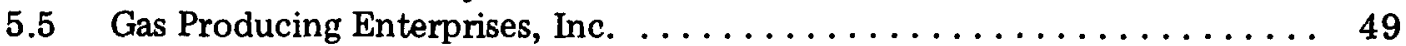

5.6 Mitchell Energy Corporation ................... 54

5.7 Mobil Research and Development Corporation $\ldots \ldots \ldots \ldots \ldots \ldots \ldots 56$

5.8 Rio Blanco Natural Gas Company .................. 58

5.9 Sandia Laboratories-Mineback $\ldots \ldots \ldots \ldots \ldots \ldots \ldots \ldots \ldots \ldots .60$ 


\section{FIGURES}

Page

Figure $3-1 \quad$ Milestone Chart - USGS $\ldots \ldots \ldots \ldots \ldots \ldots \ldots \ldots \ldots \ldots \ldots \ldots \ldots \ldots \ldots \ldots$

Figure 3-2 Greater Green River Basin Showing Wells of Interest and USGS Designated Core Areas $\ldots \ldots \ldots \ldots \ldots \ldots \ldots \ldots \ldots \ldots$

Figure 3-3 Northern Great Plains Province Showing Wells of Interest and USGS Designated Core Areas $\ldots \ldots \ldots \ldots \ldots \ldots \ldots \ldots \ldots \ldots$

Figure 3-4 Piceance Basin Showing Wells of Interest and USGS Designated Core Areas $\ldots \ldots \ldots \ldots \ldots \ldots \ldots \ldots \ldots \ldots$

Figure 3-5 Uinta Basin Showing Wells of Interest and USGS Designated Core Areas $\ldots \ldots \ldots \ldots \ldots \ldots \ldots \ldots \ldots \ldots \ldots$

Figure 3-6 Milestone Chart - Multi-Well Experiment $\ldots \ldots \ldots \ldots \ldots \ldots \ldots$

Figure 4-1 New " $O$ " Ring Configuration on the Ball Seal Area $\ldots \ldots \ldots \ldots \ldots \ldots$

Figure 4-2 Flushing Head Check Valve $\ldots \ldots \ldots \ldots \ldots \ldots \ldots \ldots \ldots \ldots \ldots \ldots$

Figure $4-3$ Milestone Chart - BETC $\ldots \ldots \ldots \ldots \ldots \ldots \ldots \ldots \ldots \ldots \ldots \ldots$

Figure $4-4 \quad$ Crack shape for a constant pressure $\ldots \ldots \ldots \ldots \ldots \ldots \ldots \ldots \ldots \ldots$

Figure $4-5$ Crack shape for a parabolic pressure $\ldots \ldots \ldots \ldots \ldots \ldots \ldots \ldots \ldots$

Figure 4-6 Crack shape for a triangular pressure $\ldots \ldots \ldots \ldots \ldots \ldots \ldots \ldots \ldots$

Figure 4-7 Milestone Chart - LLL $\ldots \ldots \ldots \ldots \ldots \ldots \ldots \ldots \ldots \ldots \ldots \ldots \ldots \ldots \ldots \ldots$

Figure $4-8$ Milestone Chart - LASL $\ldots \ldots \ldots \ldots \ldots \ldots \ldots \ldots \ldots \ldots \ldots \ldots$

Figure 4-9 Milestone Chart - Sandia $\ldots \ldots \ldots \ldots \ldots \ldots \ldots \ldots \ldots \ldots$

Figure 5-1 Production and Injection Volumes and Associated Pressure of CIG Miller No. 1 and Sprague No. 1 Wells ................ 45 


\section{Page}

Figure 5-2 Flow Rate Performance of Natural Buttes No. 9 Well $\ldots \ldots \ldots \ldots \ldots$

Figure 5-3 Flow Rate Performance of Natural Buttes No. 14 Well $\ldots \ldots \ldots \ldots \ldots$

Figure 5-4 Flow Rate Performance of Natural Buttes No. 18 Well $\ldots \ldots \ldots \ldots \ldots$

Figure 5-5 Flow Rate Performance of Natural Buttes No. 19 Well $\ldots \ldots \ldots \ldots \ldots 51$

Figure 5-6 Flow Rate Performance of Natural Buttes No. 20 Well $\ldots \ldots \ldots \ldots \ldots$

Figure 5-7 Flow Rate Performance of Natural Buttes No. 22 Well $\ldots \ldots \ldots \ldots \ldots$

Figure 5-8 Results of Exploratory Coring of Hole No. $6 \ldots \ldots \ldots \ldots \ldots$

Figure 5-9 Geometry for the Finite Element Stress Calculations $\ldots \ldots \ldots \ldots \ldots$

Figure 5-10 Horizontal in situ stress for differing values of $\sigma_{\mathrm{H}} / \sigma \mathrm{V} \ldots \ldots \ldots \ldots 2$

Figure 5-11 Milestone Chart - Sandia Mineback $\ldots \ldots \ldots \ldots \ldots \ldots \ldots \ldots$ 


\section{TABLES}

Page

Table 3-1 Summary of Wells - Greater Green River Basin $\ldots \ldots \ldots \ldots \ldots \ldots$

Table 3-2 Summary of Wells - Northern Great Plains Province $\ldots \ldots \ldots \ldots \ldots$

Table 3-3 Summary of Wells - Piceance Basin $\ldots \ldots \ldots \ldots \ldots \ldots \ldots \ldots$

Table 3-4 Summary of Wells - Uinta Basin $\ldots \ldots \ldots \ldots \ldots \ldots \ldots \ldots \ldots$

Table 4-1 Slopes of CEC Versus Surface Area Data

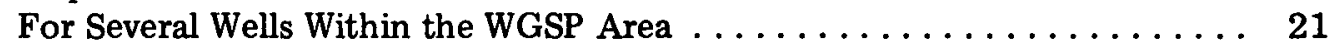

Table 4-2 Comparison of Measured and Calculated CEC $\ldots \ldots \ldots \ldots \ldots \ldots$

Table 4-3 Slopes of the CEC Versus the Potassium-40

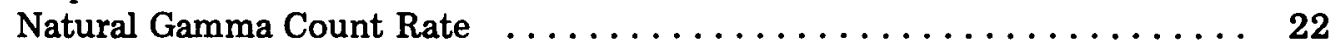

Table 4-4 Effect of Net Confining Pressure on the Slope of Klinkenberg Plots and the Klinkenberg Constant, $b \quad \ldots \ldots \ldots \ldots \ldots \ldots 22$

Table 4-5 Comparison of Measurements on the Effect of Confining Pressure on Permeability $\ldots \ldots \ldots \ldots \ldots \ldots \ldots \ldots \ldots$

Table 4-6 Whole Core Analysis Compared to Plug Analysis on

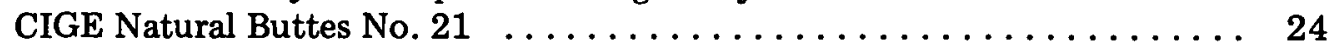

Table 4-7 PTS No. 24-19 Cores: Klinkenberg Permeability at 225 psi O.B. . . . . . 27

Table 5-1 MHF Contract Location and Frac Data $\ldots \ldots \ldots \ldots \ldots \ldots \ldots \ldots$ 


\section{SUMMARY}

This edition of the WGSP Status Report summarizes December, 1979, progress of the government-sponsored projects directed toward increasing gas production from the lowpermeability gas sands of the western United States. Background information is provided in the September, 1977, WGSP Status Report, NVO/0655-100.

The USGS continued work toward resource assessment in the four primary areas. Coring of the Rainbow Resources No. 1-3 Federal well, Sweetwater County, Wyoming, was initiated.

Research continued at the National Laboratories and Energy Technology Centers on improvement of enhanced gas recovery. Work on improved coring systems, logging studies, in situ permeability and rock/fluid interaction continued for Bartlesville Energy Technology Center. Los Alamos Scientific Laboratory continued in the nuclear magnetic resonance studies, and at Sandia Laboratories nuclear magnetic resonance testing continued on eleven cores.

The Texstream diaphragm regulator has been installed at the Colorado Interstate Gas Company cyclic injection site. Twenty-three coreholes have been completed at the Sandia Hole No. 6 formation interface fracture experiment at the Nevada Test Site. 


\section{THIS PAGE \\ WAS INTENTIONALLY \\ LEFT BLANK}




\title{
2. PROJECT MANAGEMENT
}

\subsection{Technology Transfer}

\subsubsection{Documentation Reports}

The WGSP Financial Supplement for December 1979/January 1980, has been distributed. The WGSP section of the DOE Semi-Annual Report of the Unconventional Gas Recovery Program (period ending September, 1979) is in the final drafting stages. The WGSP Project Plan, FY 1980, has been distributed. The DOE Well Test Facility Operations Manual and the WGSP Coring Program Document are being updated. The WGSP Logging Report is being reviewed and updated. Work continued on the WGSP Greater Green River Basin Review and similar reports for the Piceance and Uinta Basins.

\subsubsection{Project Data Bank}

Updating and cataloging continued on the WGSP bibliography and the WGSP map filing system.

\subsubsection{Articles and Publications}

The following articles and publications relate to the WGSP and are included in the bibliography. Abstracts are included, when available.

\author{
Factors Affecting Water Blocking and Gas Flow From Hydraulically \\ Fractured Gas Wells \\ by S. A. Holditch \\ Texas A\&M University
}

To optimize profit from low-permeability gas reservoirs, well stimulation normally is required. In a majority of the cases, a long hydraulic fracture will provide the most efficient and economic means of stimulation. To create long hydraulic fractures, a large volume of fluid, mixed with additives and granular propping agents, must be pumped into the formation. Such treatments can be expensive and require extensive engineering effort.

The fluid injected during the fracturing treatment will leak off into the formation and will reduce the relative permeability to gas in the invaded region. Near the fracture, the permeability to gas will be reduced to zero. After injection has ceased, imbibition will begin to alter the fluid distribution, and when production begins, the fracturing fluid will flow from the formation into the 
fracture. As the fracturing fluid is produced, the relative permeability to gas in the invaded zone will increase and gas will begin to flow into the fracture. In some cases, the injected fracturing fluid may reduce the formation permeability in the invaded zone. Such damage can be caused by clay swelling, precipitation of solids, or migration of released fines.

In reality, all fracturing fluids, no matter how expensive, do some damage to the reservoir adjacent to the fracture. Using clean fracturing fluids that are compatible with the formation rock and the reservoir fluid helps minimize such damage. However, in some reservoirs, the injected fracturing fluid does not readily clean up and several months of production may be required before the maximum gas flow rate is achieved. In the most extreme cases, a complete water block to gas flow can occur.

To effectively design a fracture treatment for a water-sensitive reservoir, it is essential to understand the basic reservoir mechanisms that govern flow between the fracture and the formation. Gas and water relative permeability, relative permeability hysteresis, capillary pressure, and reservoir damage all tend to complicate the analysis of reservoir flow in fractured formations. By considering the combined effects of the above parameters, it is possible to analyze a given reservoir and determine the cause of slow cleanup and reduced gas productivity.

\section{On the Development of a Wireline Tool for In Situ Stress Measurement by Hydraulic Fracturing}

by A. H. Jones and A. S. Abou-Sayed

Terra Tek, Inc.

A wireline tool is being developed for in situ stress measurements by hydraulic fracturing. In addition, laboratory and analytical studies are underway to determine the feasibility of in situ stress measurement through the casing (via perforation). This program could fill the gap that currently exists in the commercial application of in situ stress determination as a design tool for MHF stimulation of tight formations. 


\section{RESOURCE ASSESSMENT}

\subsection{U.S. Geological Survey Activities}

\subsubsection{Uinta-Piceance Basins}

Mesaverde core from the Exxon Wilkins Ridge Unit No. 1 was described and sampled. This core, from the Neslen Formation, is representative of the Neslen in part of the Tavaputs Plateau of the Uinta Basin.

Rocks from the outcrops west of the Green River were described and related to Lower Tertiary and Upper Cretaceous gas-bearing reservoir rocks in the Island, Natural Buttes and Peters Point fields in the Uinta Basin.

\subsubsection{Greater Green River Basin}

Work continued on stratigraphic analysis of Greater Green River Basin.

B. E. Law published a report entitled "Section B-B' - Subsurface and surface correlations of some Upper Cretaceous and Tertiary rocks, northern Green River Basin, Wyoming," U.S. Geological Survey Open-File Report 79-1689.

J. C. Webb completed a draft paper entitled "X-ray and quantitative mineralogy of twelve samples from the Upper Cretaceous Mesaverde Group, Washakie Basin, Wyoming."

R. E. Lanham and D. J. Markochick completed a draft paper entitled "Authigenic kaolinite in low-permeability sandstones of the Almond Formation, Washakie Basin, Wyoming."

\subsubsection{Northern Great Plains Province}

Work continued on a regional cross section from southeastern Alberta to north-central Montana.

Samples from Joseph J. C. Paine No. 1-9 Aansen well from the Little Missouri field were sent to Caprock Laboratory and Reinhart Laboratory for analyses.

An open-file report on distribution of the Niobrara chalk in North Dakota and South Dakota was prepared.

An open-file report on the pinch-out of coastal sandstones in the Eagle sandstone in central Montana was prepared. 
Petrographic analysis continued of tight reservoirs in the Eagle-Telegraph Creek interval in Alberta, Montana and North Dakota.

\subsubsection{Schedule Status}

Figure 3-1 is a milestone chart depicting the status of all USGS projects within the WGSP.

\subsection{CORE PROGRAM}

In the Greater Green River Basin, no new opportunities arose for proposed core sites. However, drilling of Rainbow Resources No. 1-3 Federal well, Sweetwater County, Wyoming, was monitored during the month for coring. The core point was reached at the end of the month, and the project will carry over into January.

\subsection{LOGGING PROGRAM}

G. C. Kukal and S. R. Anderson (CER Corporation) assisted in the logging operations of Mapco RBU No. 11-17F well, Sec. 17, T10S, R20E, Uinta County, Utah, commencing November 28. A circulated mud sample was collected (general Mud type: $\mathrm{KCl}-\mathrm{NaCl}$ brine). The well was logged as follows:

- Dual Laterolog-Gamma Ray $(8,680$ to $3,764 \mathrm{ft}$ and 8,506 to $8,186 \mathrm{ft}$ ); Microlaterolog-Caliper (failed);

- Compensated Densilog-Caliper-Simultaneous Compensated Neutron Log-Gamma Ray $(8,540$ to $3,762 \mathrm{ft}, 8,536$ to $8,220 \mathrm{ft}$ and 8,540 to $8,208 \mathrm{ft})$; and

- BHC Acoustilog Caliper-Gamma Ray $(8,553$ to $3,762 \mathrm{ft}$ and 8,536 to $8,164 \mathrm{ft})$.

Field prints of the above logs and computed log (PROLOG) were delivered on location. The Microlaterolog was judged invalid and was going to be run again following the BHC Acoustilog. However, the hole's condition deteriorated to the point that extensive logging was unjustified. When the Spectralog tool would not pass a bridge at $8,100 \mathrm{ft}$, additional open hole logging (Spectralog, Microlaterolog and Variable Density Log-Signature with SP) was cancelled. The Spectralog and Compensated Neutron or Neutron Lifetime Log will be run in casing prior to perforation.

\subsection{SURVEY OF BASIN ACTIVITIES}

\subsubsection{Greater Green River Basin}

The Greater Green River Basin was again the most productive for the month. Initial potential reports indicate 29,533 MCFD of new gas. The Almond horizon was the largest producer (15,103 MCFD), followed by the Frontier, 2nd Frontier, Fort Union, Mesaverde undifferentiated, Frontier/Muddy commingled, Frontier/Bear River commingled and the Ericson horizons. 


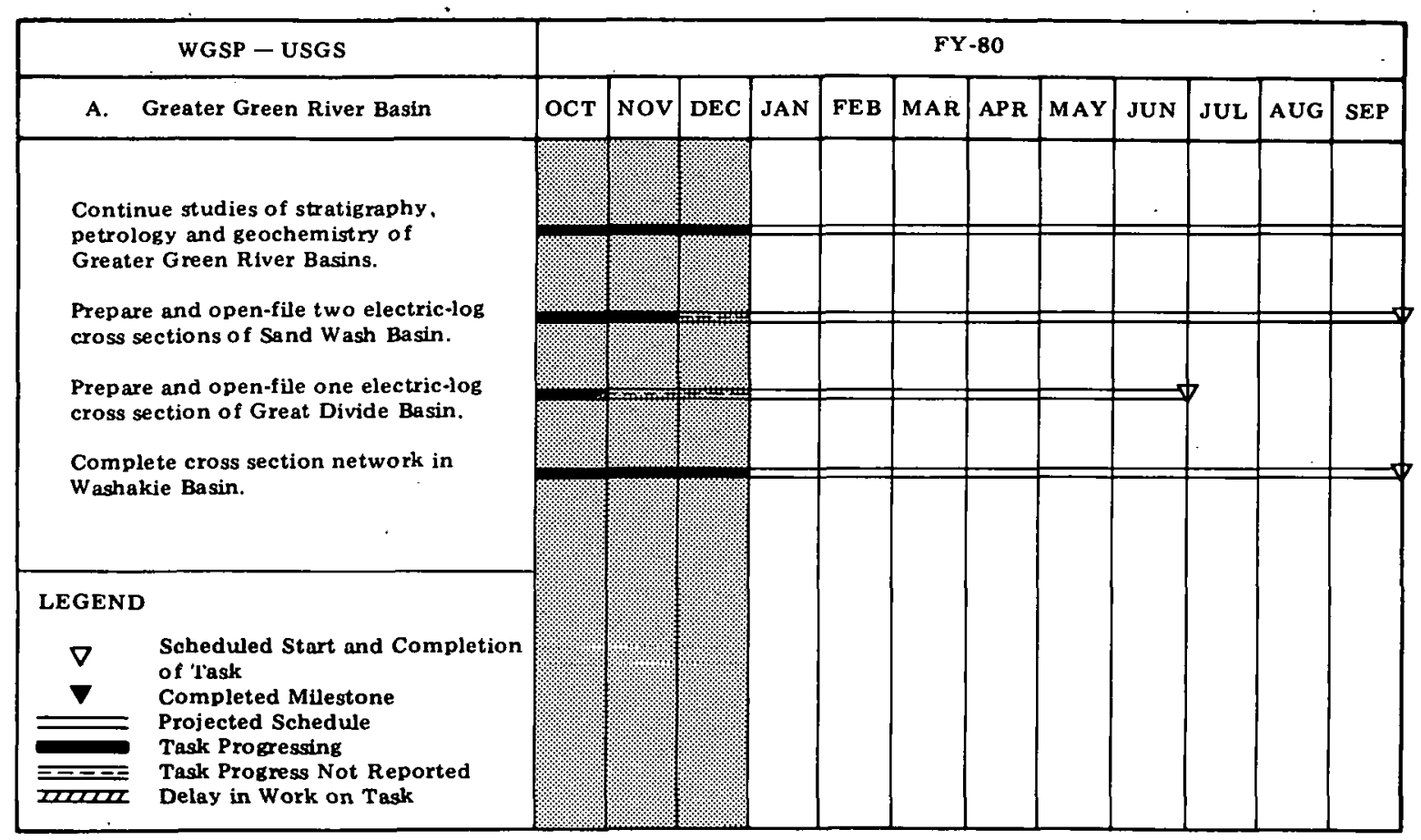

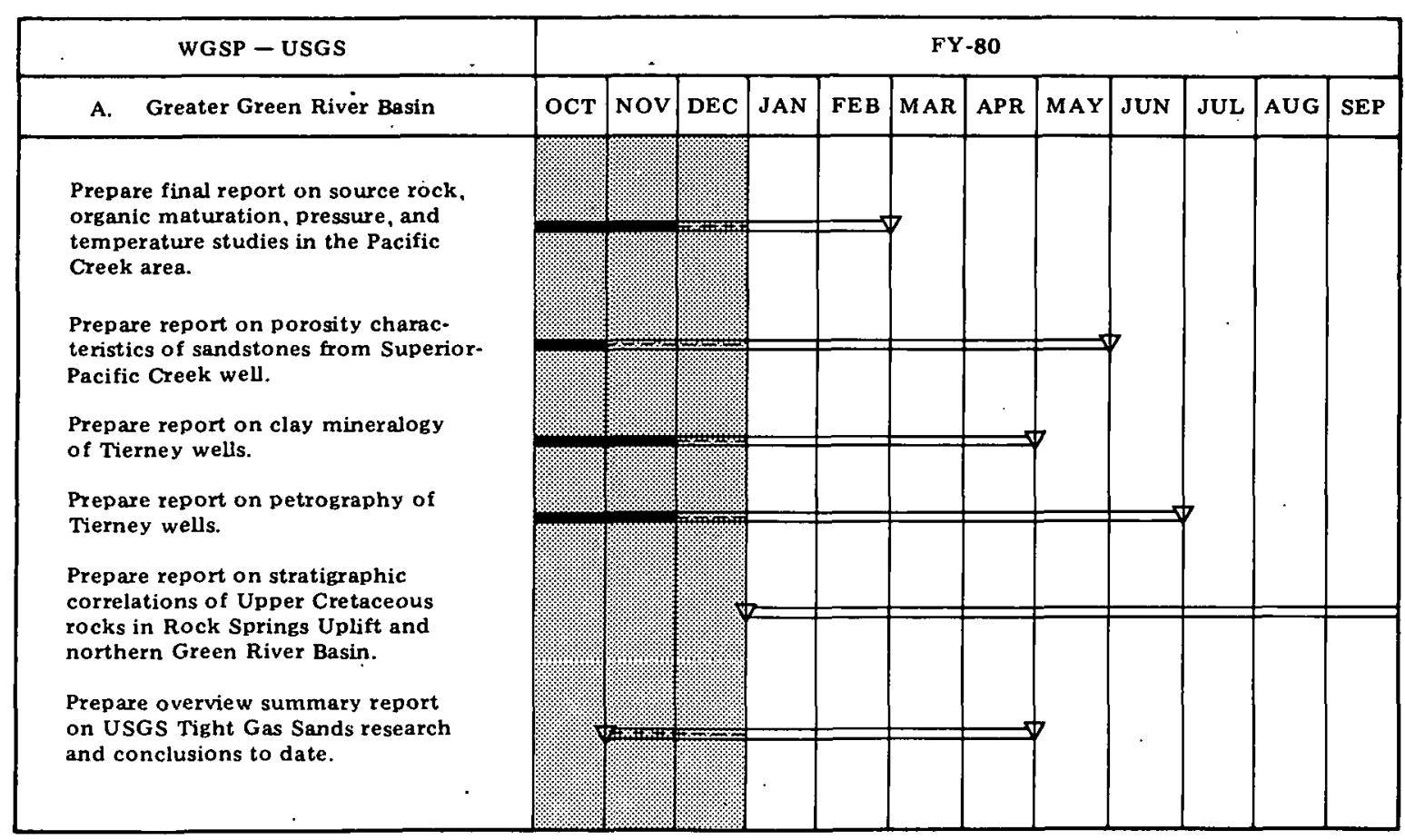

Figure 3-1 Milestone Chart-USGS 


\begin{tabular}{|c|c|c|c|c|c|c|c|c|c|c|c|c|}
\hline WGSP - USGS & \multicolumn{12}{|c|}{$\mathbf{F Y} \cdot \mathbf{8 0}$} \\
\hline B. Northern Great Plains Province & OCT & NOV & DEC & JAN & $\mathbf{F}^{\prime} \mathbf{E} B$ & MAR & APR & MAY & JUN & JUL & AUG & SEP \\
\hline \multicolumn{13}{|l|}{$\begin{array}{l}\text { Petrographic examination of producing } \\
\text { low-permeability reservoirs of SE } \\
\text { Alberta. }\end{array}$} \\
\hline \multicolumn{13}{|l|}{$\begin{array}{l}\text { Write paper on origin of biogenic gas } \\
\text { accumulations. }\end{array}$} \\
\hline \multicolumn{13}{|l|}{$\begin{array}{l}\text { Construct cross-sections from } \\
\text { western Canada to north-central } \\
\text { Montana. }\end{array}$} \\
\hline \multicolumn{13}{|l|}{$\begin{array}{l}\text { Write paper on depositional environ- } \\
\text { ments and geometries of Mosby SS } \\
\text { (Greenhorn Fm.) of north-entral } \\
\text { Montana. }\end{array}$} \\
\hline \multicolumn{13}{|l|}{$\begin{array}{l}\text { Regional subsurface study of Niobrara } \\
\text { Fm. in North and South Dakota. }\end{array}$} \\
\hline \multicolumn{13}{|l|}{$\begin{array}{l}\text { Pilot lineament study of Northern } \\
\text { Black Hills. }\end{array}$} \\
\hline \multicolumn{13}{|l|}{ Subsurface study of Groat sandstone. } \\
\hline Perianal linement man & & & - & & & & & & & & & \\
\hline Hegional lineament map. & & & & & & & & & & & & \\
\hline
\end{tabular}

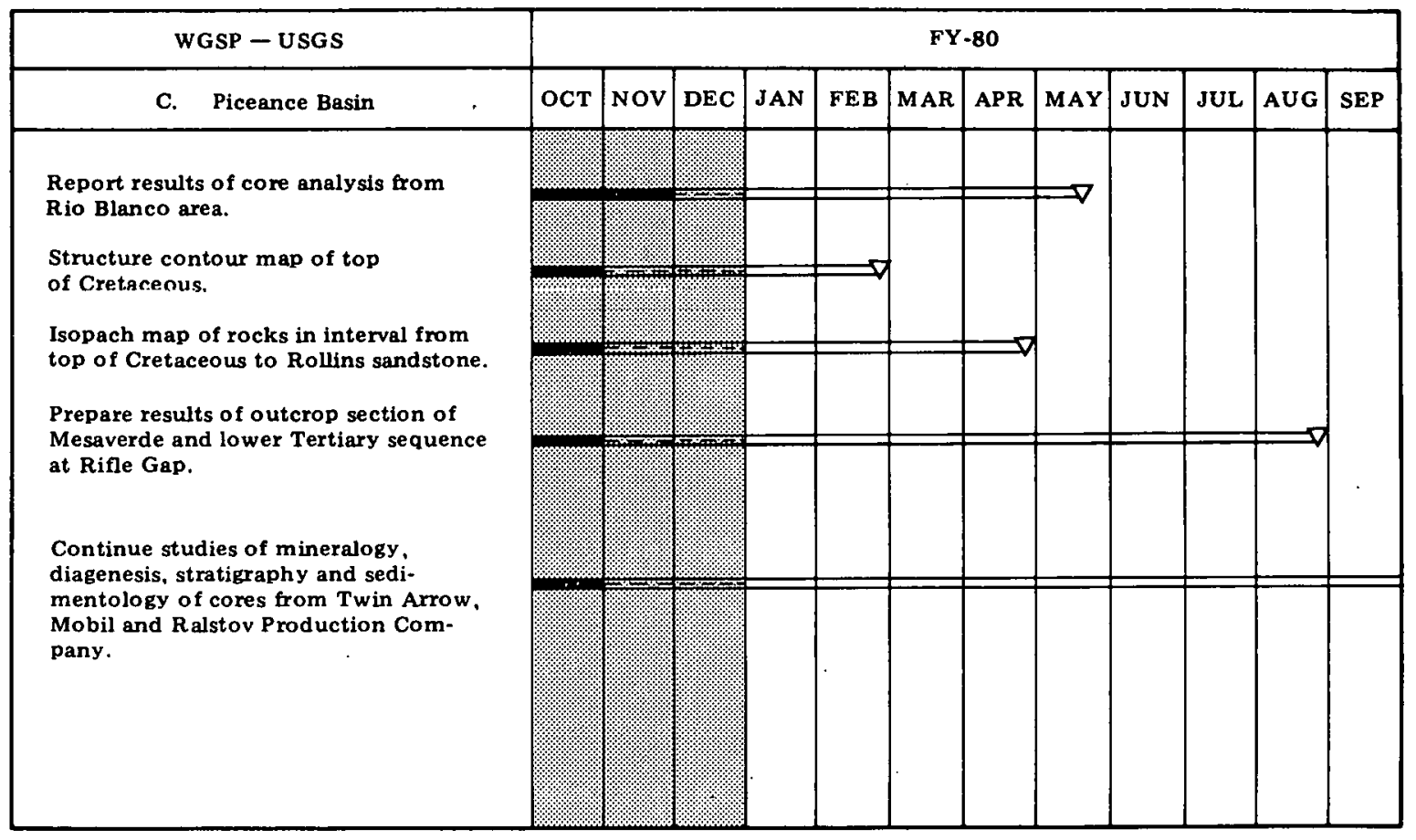

Figure 3-1 Continued 


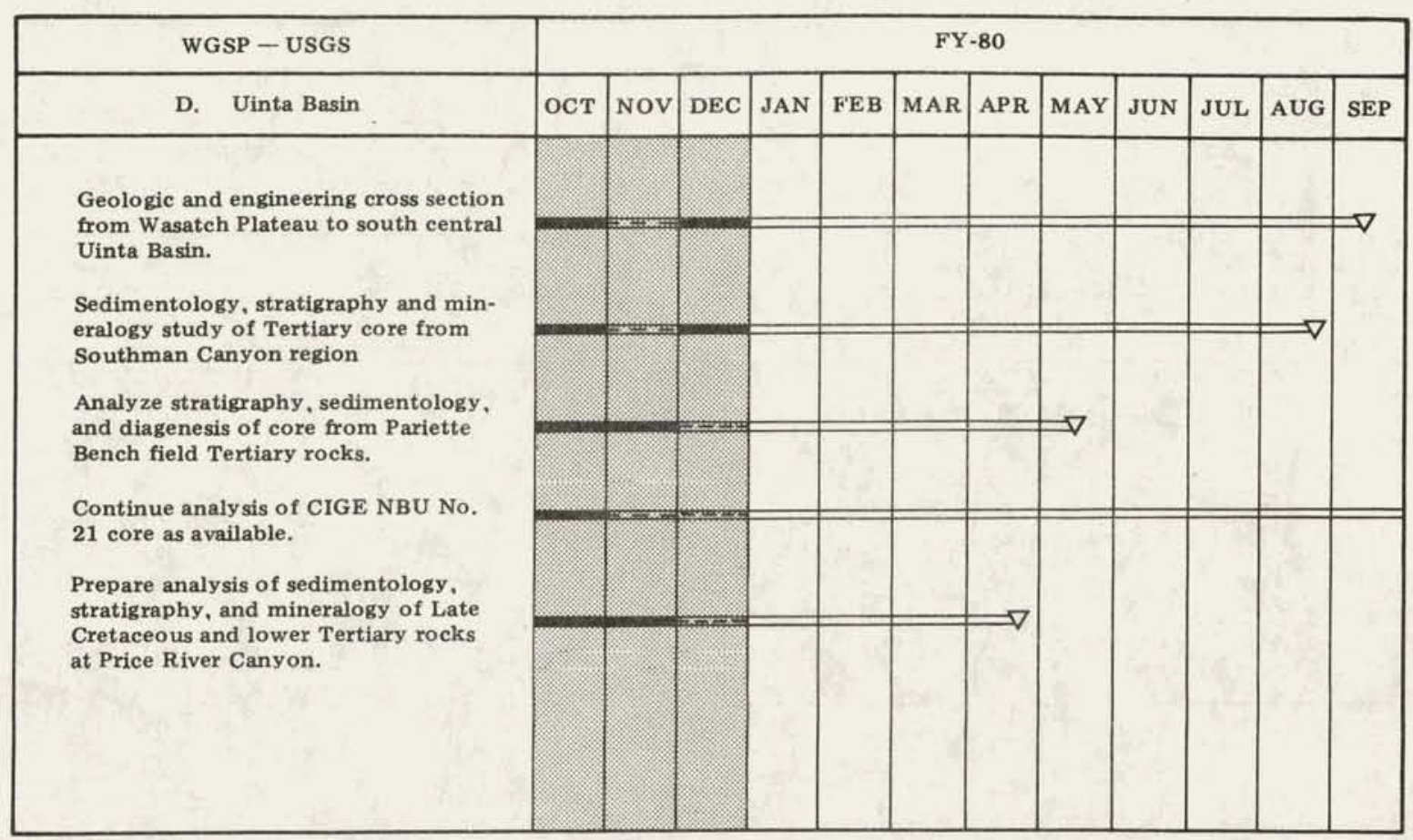

Figure 3-1 Continued

Thirty-two wells were reported complete this month: 21 development wells were reported producing, and 5 wildcat wells were reported as discoveries. Two development and 4 wildcat wells were reported D\&A. (One wildcat location was abandoned.)

Twenty new wells were staked during December: 18 development and 4 wildcat wells.

Wells of interest are summarized in Table 3-1, and Figure 3-2 shows the locations of the wells and the WGSP designated core areas.

\subsubsection{Northern Great Plains Province}

Although the Greater Green River Basin potentialed for the most new gas of the month, the Northern Great Plains Province had the most activity. There were 37 completed wells reported. Twenty-one development wells were reported producing and 12 reported D\&A. Two wildcat wells were reported as discoveries and 2 were D\&A. (Two wildcat locations were abandoned.)

Initial potential reports indicate 10,224 MCFD new gas during December. The largest producing horizon was the Eagle with 6,212 MCFD. Other horizons included the Phillips, Bowdoin/Phillips commingled, Niobrara and Bow Island horizons. 


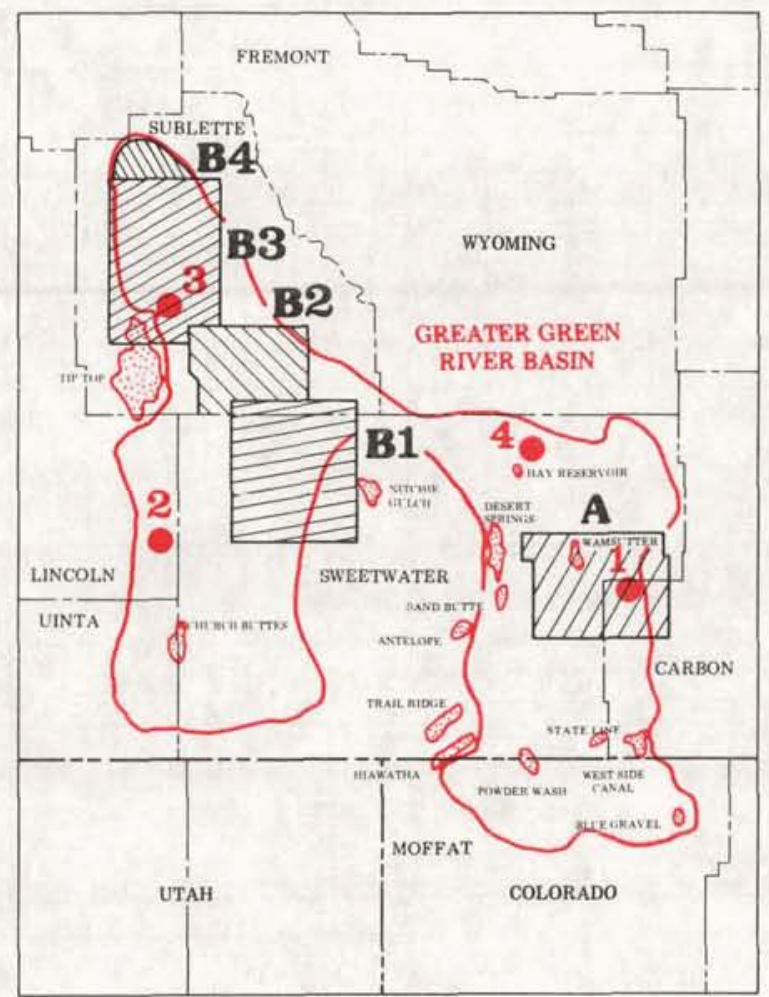

Figure 3-2 Greater Green River Basin Showing Wells of Interest and USGS Designated Core Areas (refer to Table 3-1)

Table 3-1 Summary of Wells - Greater Green River Basin

\begin{tabular}{|c|c|c|c|c|c|c|c|c|}
\hline OPERATOR & $\begin{array}{l}\text { WELL } \\
\text { NAME }\end{array}$ & $\begin{array}{l}\text { MAP } \\
\text { INDEX } \\
\text { NO.1 }\end{array}$ & $\begin{array}{l}\text { LOCATION } \\
\text { Sec/T/R }\end{array}$ & $\underset{\mathrm{ft}}{\text { HORIZON }}{ }^{2}$ & $\begin{array}{l}\text { FINAL } \\
\text { TD }\end{array}$ & $\begin{array}{l}\text { FRACTURE } \\
\text { TREATMENT }\end{array}$ & STATUS & $\begin{array}{l}\text { IPF in } \\
\text { MCFD }\end{array}$ \\
\hline Davis Oil & $\begin{array}{l}1 \text { Porter- } \\
\text { Federal }\end{array}$ & 1 & $\begin{array}{l}\text { e1/2se } 8 / 19 \mathrm{~N} / 91 \mathrm{~W} \\
\text { Unnamed Field } \\
\text { Carbon Cnty, WY }\end{array}$ & $\begin{array}{l}\text { Lewis } \\
\mathbf{8}, 348-8,370\end{array}$ & $\begin{array}{l}9,600 \\
\text { PB: } \\
8,750\end{array}$ & $\begin{array}{l}64,575 \mathrm{gal} \\
\text { emul } \\
48,000 \mathrm{lb} \\
\text { sand }\end{array}$ & $\begin{array}{l}\text { Wildeat discovery, } \\
\text { comp. 9-19-79. } \\
\text { Located in Core } \\
\text { Area A. }\end{array}$ & 280 \\
\hline $\begin{array}{l}\text { Amoco } \\
\text { Production }\end{array}$ & 8 Unit & 2 & $\begin{array}{l}\text { nwsw } 1 / 21 \mathrm{~N} / 112 \mathrm{~W} \\
\text { Whiskey Buttes } \\
\text { Field } \\
\text { Lincoln Cnty, WY }\end{array}$ & $\begin{array}{l}\text { 2nd Frontier } \\
11,086-11,118\end{array}$ & $\begin{array}{l}11,309 \\
\text { PB: } \\
11,178\end{array}$ & $\begin{array}{l}\text { Acidized w/ } \\
32,500 \mathrm{gal} \\
\text { Fract w/ } \\
380,250 \mathrm{gal} \\
\text { emul } \\
807,300 \mathrm{lb} \\
\text { sand }\end{array}$ & $\begin{array}{l}\text { Develop. well } \\
\text { comp. 6-28-79. } \\
\text { No cores or tests. }\end{array}$ & 545 \\
\hline $\begin{array}{l}\text { Woods } \\
\text { Petroleum }\end{array}$ & 23-1 Guio & 3 & $\begin{array}{l}\text { swne } 23 / 30 \mathrm{~N} / \\
112 \mathrm{~W} \\
\text { Wildcat Field } \\
\text { Sublette Cnty, WY }\end{array}$ & $\begin{array}{l}\text { Frontier } \\
14,000\end{array}$ & 14,662 & $\begin{array}{l}\text { Acidized } \\
\text { twice w/ } \\
\text { total } 7,000 \\
\text { gal, Fract } \\
\text { w/100,000 } \\
\text { gal gel } \\
100,000 \mathrm{lb} \\
\text { sand }\end{array}$ & $\begin{array}{l}\text { Wildcat test, } \\
\text { comp. 10-19-79 } \\
\text { D\&A. No cores. } \\
\text { Located in Core } \\
\text { Area B3. }\end{array}$ & \\
\hline $\begin{array}{l}\text { Energy } \\
\text { Reserves } \\
\text { Group }\end{array}$ & $\begin{array}{l}1-13 \\
\text { Nickey } \\
\text { Unit }\end{array}$ & 4 & $\begin{array}{l}\text { nwse } 13 / 24 \mathrm{~N} / 96 \mathrm{~W} \\
\text { Unnamed Field } \\
\text { Sweetwater Cnty, } \\
\text { WY }\end{array}$ & $\begin{array}{l}\text { Almond } \\
12,303-12,483 \\
\text { (gross) }\end{array}$ & 12,550 & $\begin{array}{l}\text { Acidized w/ } \\
5,000 \mathrm{gal} \\
\text { Fract w/ } \\
123,772 \mathrm{gal} \\
\text { fluid } \\
136,386 \mathrm{lb} \\
\text { sand }\end{array}$ & $\begin{array}{l}\text { Wildcat discovery, } \\
\text { comp. 10-25-79. }\end{array}$ & 919 \\
\hline
\end{tabular}

${ }^{1}$ Refer to Figure 3-2

${ }^{2}$ Horizon - projected depth or producing interval 
Eight new development and five new wildcat wells were reported this month.

Wells of interest are summarized in Table 3-2 and shown in Figure 3-3.

\subsubsection{Piceance Basin}

Seventeen wells were reported complete for December: 12 development wells were reported producing, 4 wildcat wells were reported as discoveries, and 1 wildcat well was D\&A. From the 16 reported producers, there was an initial potential of 5,890 MCFD new gas. (Four IPFs were not available). The Mancos B ( 3,487 MCFD) was the largest producing horizon, followed by the Corcoran, Mancos undifferentiated and Wasatch horizons.

Eleven new development and 1 new wildcat well were staked by month's end.

Wells of interest are listed in Table 3-3, and Figure 3-4 shows the locations of these wells and the WGSP designated core areas.

\subsubsection{Uinta Basin}

Activity was slow again this month in the Uinta Basin. Five development wells were reported as producers with a potential of 4,916 MCFD new gas. (One development location was abandoned.) Production was mainly from the Mesaverde undifferentiated horizon (3,050 MCFD), but the Wasatch and Mesaverde/Wasatch commingled also contributed.

Eleven new development wells were staked during December.

A summary of wells of interest is in Table 3-4, and Figure 3-5 shows the location of the wells and the WGSP designated core areas.

\subsection{K GEOENERGY}

\subsubsection{Coring and Logging Hole DOE-GC-1}

Corehole DOE-GC-1, Sec. 16, T17N, R24E, Grand County, Utah (Uinta Basin), was foam drilled to a total depth of $1,200 \mathrm{ft}$ and was reamed out to 6-1/4 in. The well was mudded up in $200 \mathrm{ft}$ increments with the drill bit suspended about $50 \mathrm{ft}$ above the bottom of the interval being filled. Mud loss was encountered in the bottom section of the hole. This was not unexpected because there was fluid loss in this section while drilling and reaming. Increasing the concentration of lost circulation material finally stopped the mud loss in the bottom of the hole, and mudding up continued without any problems until the last 200-ft interval was reached. At this point there was a slow mud loss. It was speculated that either the full hole mud column weight reopened a fracture that had been sealed with lost circulation material, or a series of shallow fractures were present that slowly accepted the mud. The mud level stabilized around $150 \mathrm{ft}$ subsurface, so shallow fractures seemed to be the problem. 


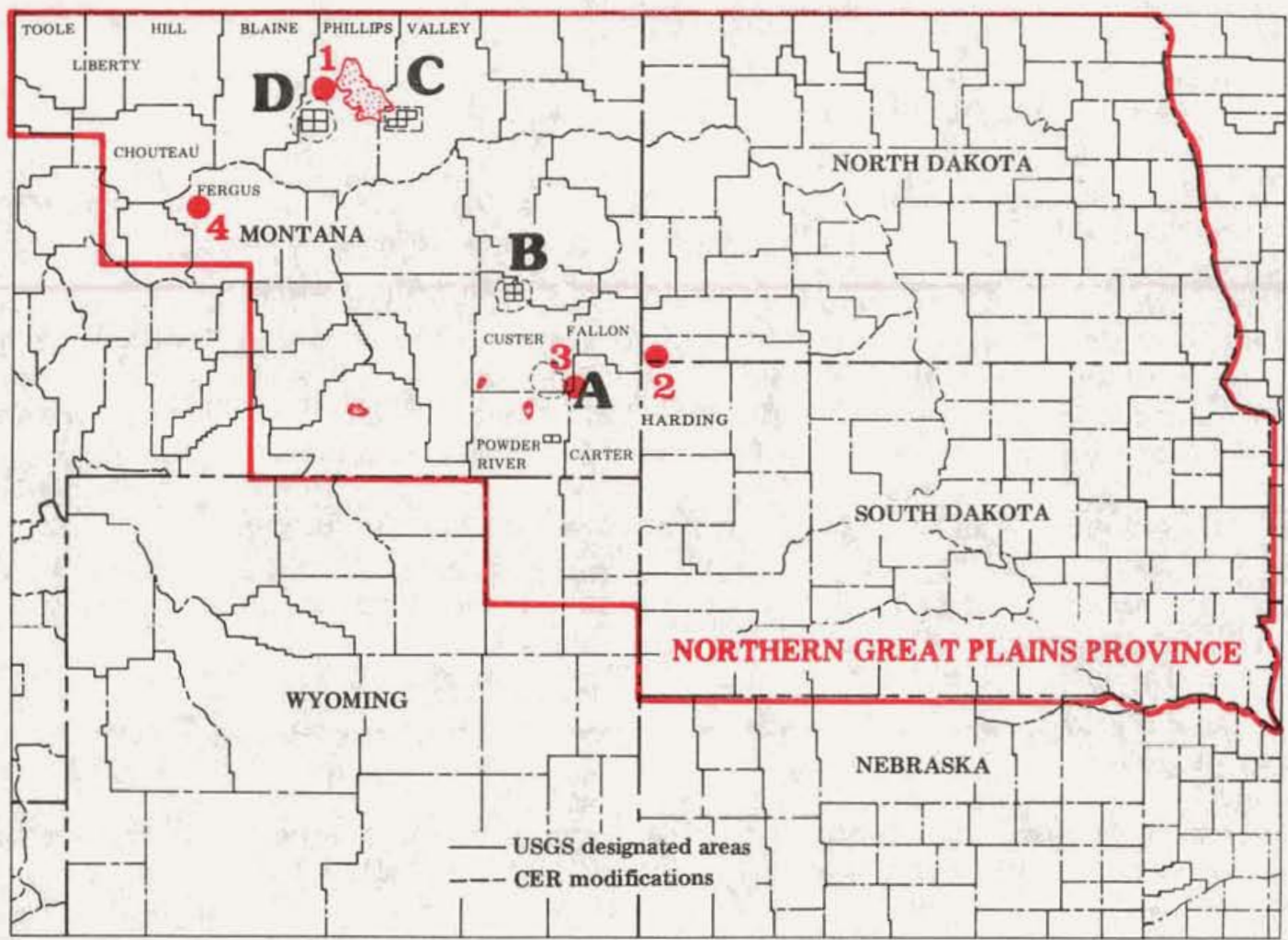

Figure 3-3 Northern Great Plains Province Showing Wells of Interest and USGS Designated Core Areas (refer to Table 3-2)

Table 3-2 Summary of Wells - Northern Great Plains Province

\begin{tabular}{|c|c|c|c|c|c|c|c|c|}
\hline OPERATOR & $\begin{array}{l}\text { WELL } \\
\text { NAME }\end{array}$ & $\begin{array}{l}\text { MAP } \\
\text { INDEX } \\
\text { NO.1 }\end{array}$ & $\begin{array}{l}\text { LOCATION } \\
\text { Sec/T/R }\end{array}$ & $\underset{f t}{\text { HORIZON }}{ }^{2}$ & $\begin{array}{c}\text { FINAL } \\
\text { TD }\end{array}$ & $\begin{array}{l}\text { FRACTURE } \\
\text { TREATMENT }\end{array}$ & STATUS & $\begin{array}{l}\text { IPF in } \\
\text { MCFD }\end{array}$ \\
\hline $\begin{array}{l}\text { Xeno } \\
\text { Incorporated }\end{array}$ & $\begin{array}{l}16-15 \\
\text { Wagner }\end{array}$ & 1 & $\begin{array}{l}\text { sese } 15 / 32 \mathrm{~N} / 28 \mathrm{E} \\
\text { Unnamed Field } \\
\text { Phillips Cnty, MT }\end{array}$ & $\begin{array}{l}\text { Niobrara } \\
1,539-1,551 \\
\text { (gross) }\end{array}$ & $\begin{array}{l}1,594 \\
\mathrm{~PB}: \\
1,578\end{array}$ & $\begin{array}{l}30,000 \mathrm{lb} \\
\text { sand }\end{array}$ & $\begin{array}{l}\text { Wildeat discovery, } \\
\text { comp. 10-24-79. } \\
\text { No cores or tests. }\end{array}$ & 34 \\
\hline $\begin{array}{l}\text { Joseph } \\
\text { J. C. } \\
\text { Paine }\end{array}$ & $\begin{array}{l}2-23 \\
\text { Lowe }\end{array}$ & 2 & $\begin{array}{l}\text { nenw } 23 / 1.29 \mathrm{~N} / \\
\text { 106w } \\
\text { Little Missouri } \\
\text { Field } \\
\text { Bowman Cnty, ND }\end{array}$ & $\begin{array}{l}\text { Eagle } \\
1,322-1,469 \\
\text { (gxoss) }\end{array}$ & $\begin{array}{l}1,600 \\
\text { PB: } \\
1,526\end{array}$ & $\begin{array}{l}20,025 \mathrm{gal} \\
\text { fluid } \\
50,000 \mathrm{lb} \\
\text { sand }\end{array}$ & $\begin{array}{l}\text { Develop. well, } \\
\text { comp. } 9-27-79 \text {. } \\
\text { No cores or tests. }\end{array}$ & 120 \\
\hline $\begin{array}{l}\text { Brownlie, } \\
\text { Wallace, } \\
\text { Armstrong } \\
\text { \& Bander }\end{array}$ & $\begin{array}{l}17-12 \\
\text { Miles }\end{array}$ & 3 & $\begin{array}{l}\text { swnw } 17 / 1 \mathrm{~N} / 54 \mathrm{E} \\
\text { Wildcat Field } \\
\text { Custer Cnty, MT }\end{array}$ & $\begin{array}{l}\text { Shannon } \\
1,900\end{array}$ & & & $\begin{array}{l}\text { Wildcat test, } \\
\text { reported 12-5-79. }\end{array}$ & \\
\hline $\begin{array}{l}\text { South } \\
\text { Ranch Oil }\end{array}$ & 1 Dickson & 4 & $\begin{array}{l}\text { sese } 9 / 21 \mathrm{~N} / 15 \mathrm{E} \\
\text { Wildcat Field } \\
\text { Fergus Cnty, MT }\end{array}$ & $\begin{array}{l}\text { Muddy } \\
1,287\end{array}$ & & 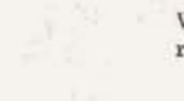 & $\begin{array}{l}\text { Wildcat test, } \\
\text { reported 11-27-79. }\end{array}$ & \\
\hline
\end{tabular}

${ }_{2}^{1}$ Refer to Figure 3-3

2 Horizon - projected depth

or producing interval 


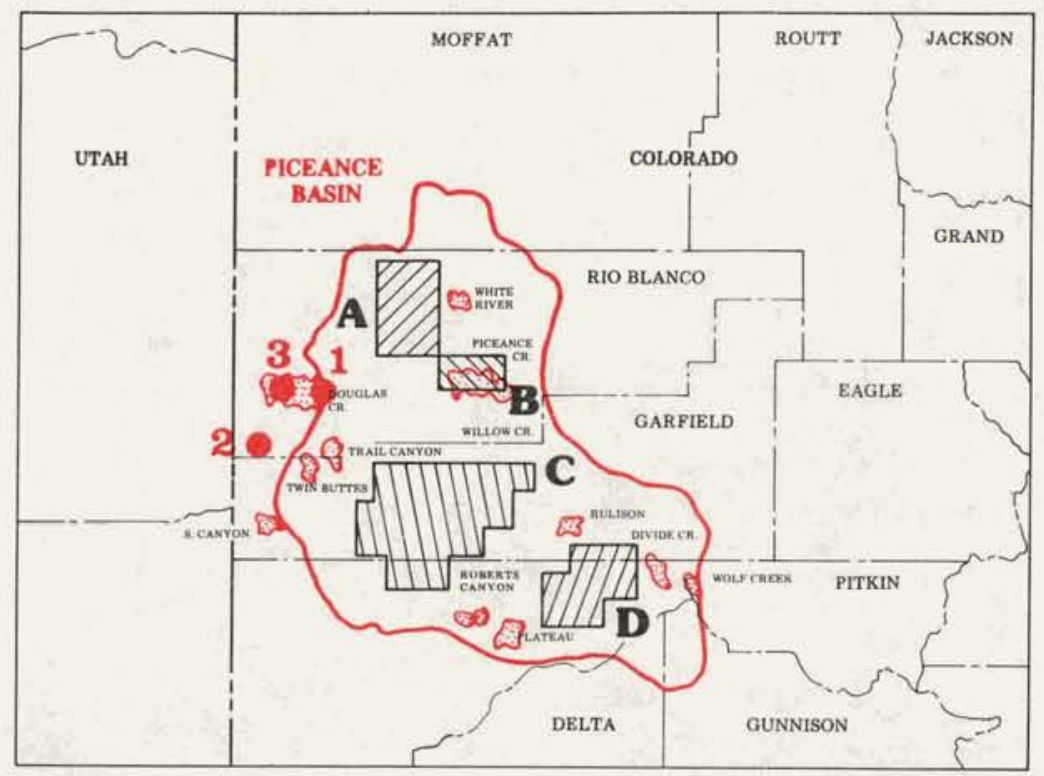

Figure 3-4 Piceance Basin Showing Wells of Interest and USGS Designated Core Areas (refer to Table 3-3)

Table 3-3 Summary of Wells - Piceance Basin

\begin{tabular}{|c|c|c|c|c|c|c|c|c|}
\hline OPERATOR & $\begin{array}{l}\text { WELL } \\
\text { NAME }\end{array}$ & $\begin{array}{c}\text { MAP } \\
\text { INDEX } \\
\text { NO.1 }\end{array}$ & $\begin{array}{l}\text { LOCATION } \\
\text { Sec/T/R }\end{array}$ & $\underset{\mathrm{ft}}{\text { HORIZON }}$ & $\begin{array}{l}\text { FINAL } \\
\text { TD }\end{array}$ & $\begin{array}{l}\text { FRACTURE } \\
\text { TREATMENT }\end{array}$ & STATUS & $\begin{array}{l}\text { IPF in } \\
\text { MCFD }\end{array}$ \\
\hline $\begin{array}{l}\text { Wexpro } \\
\text { Company }\end{array}$ & $\begin{array}{l}28-3 \\
\text { Federal }\end{array}$ & 1 & $\begin{array}{l}\text { swse } 28 / 2 S / 101 W \\
\text { Cathedral Field } \\
\text { Rio Blanco Cnty, } \\
\text { CO }\end{array}$ & $\begin{array}{l}\text { Mancos B } \\
1,769-2,024\end{array}$ & $\begin{array}{l}2,197 \\
\text { PB: } \\
2,141\end{array}$ & $\begin{array}{ll}\text { Acidized w/ } & \text { D } \\
1,000 \mathrm{gal} & \mathrm{c} \\
\text { Fract w/ } & \text { a } \\
68,000 \mathrm{gal} & \mathrm{o} \\
\text { gel, } 240,000 & \mathrm{fr} \\
\text { lb sand } & \text { fc } \\
15,707 \mathrm{gal} & \\
\mathrm{CO}_{2} & \end{array}$ & $\begin{array}{l}\text { Develop. well } \\
\text { comp. 9-20-79 } \\
\text { as SIGW. No cores } \\
\text { or tests. Largest } \\
\text { fracture job reported } \\
\text { for the month. }\end{array}$ & $\begin{array}{l}\text { (712) } \\
\text { ed }\end{array}$ \\
\hline $\begin{array}{l}\text { Coseka } \\
\text { Resources }\end{array}$ & $\begin{array}{l}14-20-4- \\
103 \\
\text { Federal }\end{array}$ & 2 & $\begin{array}{l}\text { nenw } 20 / 4 \text { S/103w } \\
\text { Boondocks Field } \\
\text { Rio Blanco Cnty, } \\
\text { CO }\end{array}$ & $\begin{array}{l}\text { Mancos B } \\
3,265-3,300\end{array}$ & $\begin{array}{l}6,679 \\
\text { PB: } \\
3,575\end{array}$ & $\begin{array}{l}15,632 \mathrm{gal} \\
\text { fluid } \\
43,000 \mathrm{lb} \\
\text { sand }\end{array}$ & $\begin{array}{l}\text { Wild cat shallow } \\
\text { pool discovery, } \\
\text { comp. 10-25-79. } \\
\text { No cores or tests. }\end{array}$ & 120 \\
\hline $\begin{array}{l}\text { Chandler } \\
\text { \& Associates }\end{array}$ & $\begin{array}{l}\text { 5-3-2-2 } \\
\text { Federal }\end{array}$ & 3 & $\begin{array}{l}\text { swnw } 3 / 2 \mathrm{~S} / 102 \mathrm{~W} \\
\text { Dragon Trail } \\
\text { Rio Blanco Cnty, } \\
\text { CO }\end{array}$ & $\begin{array}{l}\text { Mancos B } \\
2,733-2,805\end{array}$ & 3,243 & $\begin{array}{l}\text { Acidized w/ } \\
1,500 \text { gal } \\
\text { Fract } w / \\
60,000 \text { gal } \\
\text { fluid } \\
226,000 \mathrm{lb} \\
\text { sand }\end{array}$ & $\begin{array}{l}\text { Wildcat outpost } \\
\text { well, comp. } \\
\text { 11-12-79. }\end{array}$ & 160 \\
\hline
\end{tabular}

${ }_{2}^{1}$ Refer to Figure 3-4

Horizon - projected depth

or producing interval 


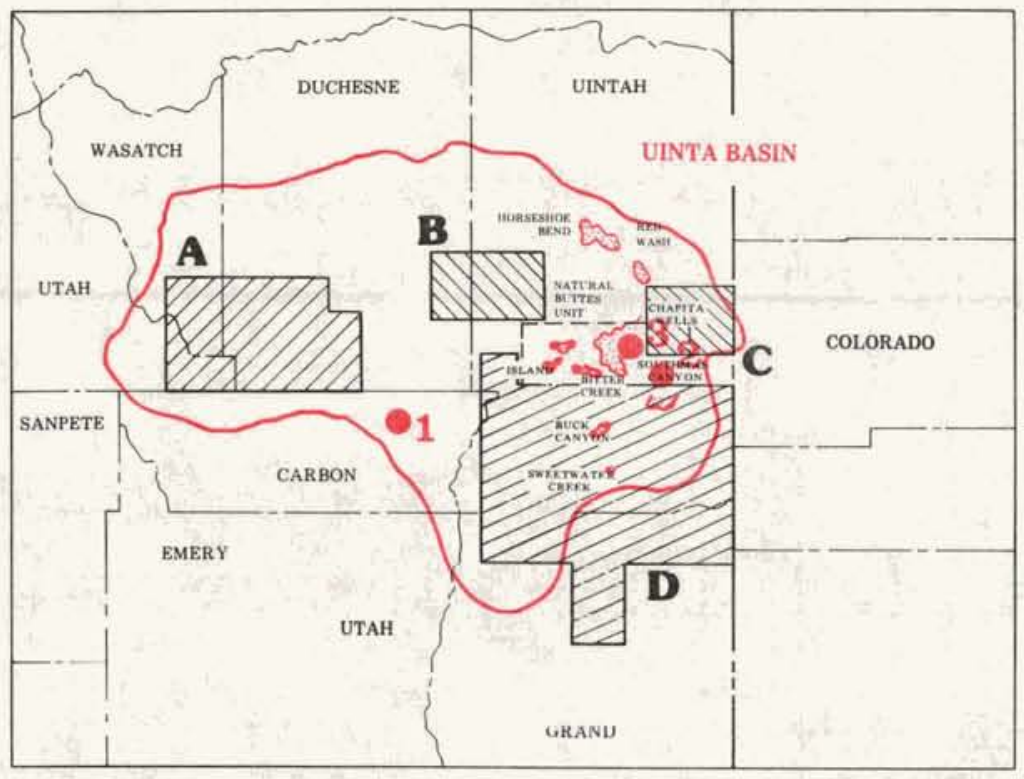

Figure 3-5 Uinta Basin Showing Wells of Interest and USGS Designated Core Areas (refer to Table 3-4)

Table 3-4 Summary of Wells - Uinta Basin

\begin{tabular}{|c|c|c|c|c|c|c|c|c|}
\hline OPERATOR & $\begin{array}{l}\text { WELL } \\
\text { NAME }\end{array}$ & $\begin{array}{l}\text { MAP } \\
\text { INDEX } \\
\text { NO. } 1\end{array}$ & $\begin{array}{l}\text { LOCATION } \\
\text { Sec/T/R }\end{array}$ & $\underset{\mathrm{ft}}{\text { HORIZON }}{ }^{2}$ & $\begin{array}{c}\text { FINAL } \\
\text { TD }\end{array}$ & $\begin{array}{l}\text { FRACTURE } \\
\text { TREATMENT }\end{array}$ & STATUS & $\begin{array}{l}\text { IPF in } \\
\text { MCFD }\end{array}$ \\
\hline Reserve Oil & $\begin{array}{l}101 \text { Jacks } \\
\text { Canyon }\end{array}$ & 1 & $\begin{array}{l}\text { swse } 33 / 12 S / 16 \mathrm{E} \\
\text { Peters Point Field } \\
\text { Carbon Cnty, UT }\end{array}$ & 3,200 & 3,175 & $\begin{array}{l}\text { I } \\
\text { c } \\
\text { t }\end{array}$ & $\begin{array}{l}\text { Develop, well, } \\
\text { comp. 11-14-79; } \\
\text { temp. abnd. }\end{array}$ & \\
\hline $\begin{array}{l}\text { Ensearch } \\
\text { Exploration }\end{array}$ & $\begin{array}{l}\text { 1-14 White } \\
\text { River- } \\
\text { Federal }\end{array}$ & 2 & $\begin{array}{l}\text { nenw } 14 / 10 S / 23 E \\
\text { Natural Buttes } \\
\text { Field } \\
\text { Uintah Cnty, UT }\end{array}$ & $\begin{array}{l}\text { Mesaverde } \\
6,456-7,929 \\
\text { (gross) }\end{array}$ & $\begin{array}{l}8,205 \\
\text { PB: } \\
8,214\end{array}$ & $\begin{array}{ll}260,000 \mathrm{gal} & \text { I } \\
\text { gel, 480,000 } & \text { c } \\
\text { lb sand } & \text { I } \\
& \text { I } \\
& \text { jc } \\
& \text { n }\end{array}$ & $\begin{array}{l}\text { Develop. well, } \\
\text { comp. 10-20-79. } \\
\text { No cores or tests. } \\
\text { Largest fracture } \\
\text { job reported this } \\
\text { month. }\end{array}$ & 2,300 \\
\hline $\begin{array}{l}\text { Gas } \\
\text { Producing } \\
\text { Enterprises }\end{array}$ & $\begin{array}{l}16 \text { Natural } \\
\text { Buttes Unit }\end{array}$ & 3 & $\begin{array}{l}\text { nwse } 35 / 9 S / 22 E \\
\text { Natural Buttes } \\
\text { Field } \\
\text { Uintah Cnty, UT }\end{array}$ & $\begin{array}{l}\text { Wasatch } \\
5,222-5,243 \\
\text { (gross) } \\
\text { Mesaverde } \\
8,041-8,797 \\
\text { (Commingled) }\end{array}$ & $\begin{array}{l}9,015 \\
\text { PB: } \\
8,854\end{array}$ & $\begin{array}{l}\text { Acidized. } \\
\text { Fract w/ } \\
60,480 \mathrm{gal} \\
\text { emul } \\
103,000 \mathrm{lb} \\
\text { sand }\end{array}$ & $\begin{array}{l}\text { Develop. well, } \\
\text { first report and } \\
\text { comp. } 4-5-78 \text {. } \\
\text { Old well worked } \\
\text { over. }\end{array}$ & 1,300 \\
\hline
\end{tabular}

${ }_{2}^{1}$ Refer to Figure 3-5

${ }^{2}$ Horizon - projected depth

or producing interval 
Near the end of the coring operation, Seismic International moved into the area to begin their high resolution survey. However, the rig caused so much background noise that recording could not continue with the rig running. A compromise was made by shutting down the rig during the recording time (estimated at 15 minutes) and drilling during SI's moves. However, on one occasion the shutdown time approached two hours. Leaving the core barrel and drill string dead and on bottom for this length of time while shooting was too risky and the decision was made to alternate shooting and drilling. This resulted in four extra days of standby plus one day of drilling without satisfactory progress. The geophysical crew had to standby for about 5 days.

Dresser-Atlas and GO Wireline Services are unable to field their high resolution dipmeters in the Colorado/Utah area during the December to February period, so logging was done with only Schlumberger.

The logging encountered a few problems. The hole tended to close between 265 and 300 $\mathrm{ft}$ and between 1,050 and 1,200 ft. In addition, the mud level continued to drop toward $150 \mathrm{ft}$ while logging. The hole was opened, allowing the logging of the upper part of the hole. However, the logging sonde kept getting hung up around 1,050 ft, so the well was only logged to $1,046 \mathrm{ft}$. The falling fluid level was taken care of by logging the hole, pulling the sonde up in the casing, filling the hole, and making a repeat run over the top $200 \mathrm{ft}$ of hole (the mud level was still up in the casing during this part of the operation).

After logging, the mud was blown out of the hole to a depth of about $500 \mathrm{ft}$ and the rig was moved so the geophysical crew could perform some in-hole shooting. However, they could not get below $300 \mathrm{ft}$. The rig then moved back over the hole, which was cleaned out and mudded up. A short joint of 7-in. casing was added on top of the original casing.

The current condition of the suspended operation is:

- The 7 in. casing stands about 18 in. above ground level;

- the casing is closed on top with a screwed cap;

- the hole was cleaned out and filled with mud; and

- the mud pits are still open adjacent to the hole.

Based on past experience, $\mathrm{C} \mathrm{K}$ GeoEnergy will probably move in a small rig, clean out the hole and fill it with mud to the surface as the initial phase of any subsequent logging operation. Dresser and GO will be scheduled on subsequent days as soon as the snow has melted in the area (March-April).

The Schlumberger logging data will be processed and the phase report covering coring and logging will be completed.

\subsubsection{Evaluation of Sandstone Outcrops - Green River and Wind River Basins, Wyoming}

Processing of the information obtained during the 1979 field season is continuing. 


\subsection{MULTI-WELL EXPERIMENT}

Site acquisition is being focused in the Vega Reservoir area, east of Collbran, Colorado. Figure $3-6$ is a milestone chart depicting the WGSP progress of the multi-well experiment program.

\begin{tabular}{|c|c|c|c|c|c|c|c|c|c|c|c|c|c|}
\hline \multirow{2}{*}{\multicolumn{2}{|c|}{$\frac{\text { WGSP }}{\text { MULTI-WELL EXPERIMENT }}$}} & \multicolumn{12}{|c|}{ FY -80 } \\
\hline & & OCT & NOV & DEC & JAN & F'EB & MAR & APR & MAY & JUN & JUL & AUG & SEP \\
\hline \multicolumn{14}{|c|}{ Planning Activitles } \\
\hline \multicolumn{14}{|c|}{ Site Acquisition and Permits } \\
\hline \multicolumn{14}{|c|}{ Site Preparation } \\
\hline \multicolumn{14}{|c|}{ Drilling, Coring, Logging } \\
\hline \multicolumn{14}{|c|}{ Well Testing } \\
\hline \multicolumn{14}{|c|}{ Core Analyses } \\
\hline \multicolumn{14}{|c|}{ LEGEND } \\
\hline$\nabla$ & $\begin{array}{l}\text { Scheduled Start and Completion } \\
\text { of Task }\end{array}$ & & & & & & & & & & & & \\
\hline$\nabla$ & Completed Milestone & & & & & & & & & & & & \\
\hline 0 & Task Progressing & & & & & & & & & & & & \\
\hline$\equiv=$ & Task Progress Not Reported & & & & & & & & & & & & \\
\hline & Delay in Work on Task & & & & & & & & & & & & \\
\hline
\end{tabular}

Figure 3-6 Milestone Chart-Multi-Well Experiment 


\section{RESEARCH AND DEVELOPMENT BY ENERGY TECHNOLOGY CENTERS AND NATIONAL LABORATORIES}

\subsection{BARTLESVILLE ENERGY TECHNOLOGY CENTER}

\subsubsection{Improved Pressure Coring System - Sandia Laboratories}

\subsubsection{Core Retriever Design and Test}

Data analysis on 120 pressure coring runs from July through September, 1979, gave the following results:

\begin{tabular}{lcr} 
Pressure & Number & Percent \\
\hline Acceptable Pressure & 77 & 64 \\
Overpressured Barrels & 11 & 9 \\
Underpressured Barrels & 18 & 15 \\
Zero-pressured Barrels & 14 & 12
\end{tabular}

An analysis of problems causing these malfunctions is as follows:

\begin{tabular}{lcc}
\multicolumn{1}{c}{ Problem } & Malfunction & $\begin{array}{c}\text { Percent of } \\
\text { Total Barrels }\end{array}$ \\
\hline Regulator Problems & 23 & 19 \\
Ball Problems & 10 & 8 \\
Other Problems & 10 & 8
\end{tabular}

The regulator section of the pressure core barrel has been redesigned and is undergoing laboratory testing prior to field tests. A suspected regulator malfunction due to bottom hole vibration is being investigated. This investigation will be included in the Sandia/ DOWDCO pressure coring improvement program.

The ball seal has been redesigned and is undergoing field evaluation. The new arrangement uses two O-rings in series to give a statistically better chance of sealing the ball. (See Figure 4-1).

Some pressure failures were caused by the core breaking lengthwise and extending through the ball valve, which caused a malfunction. This problem has been eliminated by an operational change, which requires the operator to set down with a 10,000 lb load on bottom after the core is broken. This ensures maximum insertion of the broken core into the barrel.

A check valve developed for the flushing head (Figure 4-2) has been field proven. It retains core pressure when leaks develop in the high pressure gas side of the core barrel pressure regulator section. 

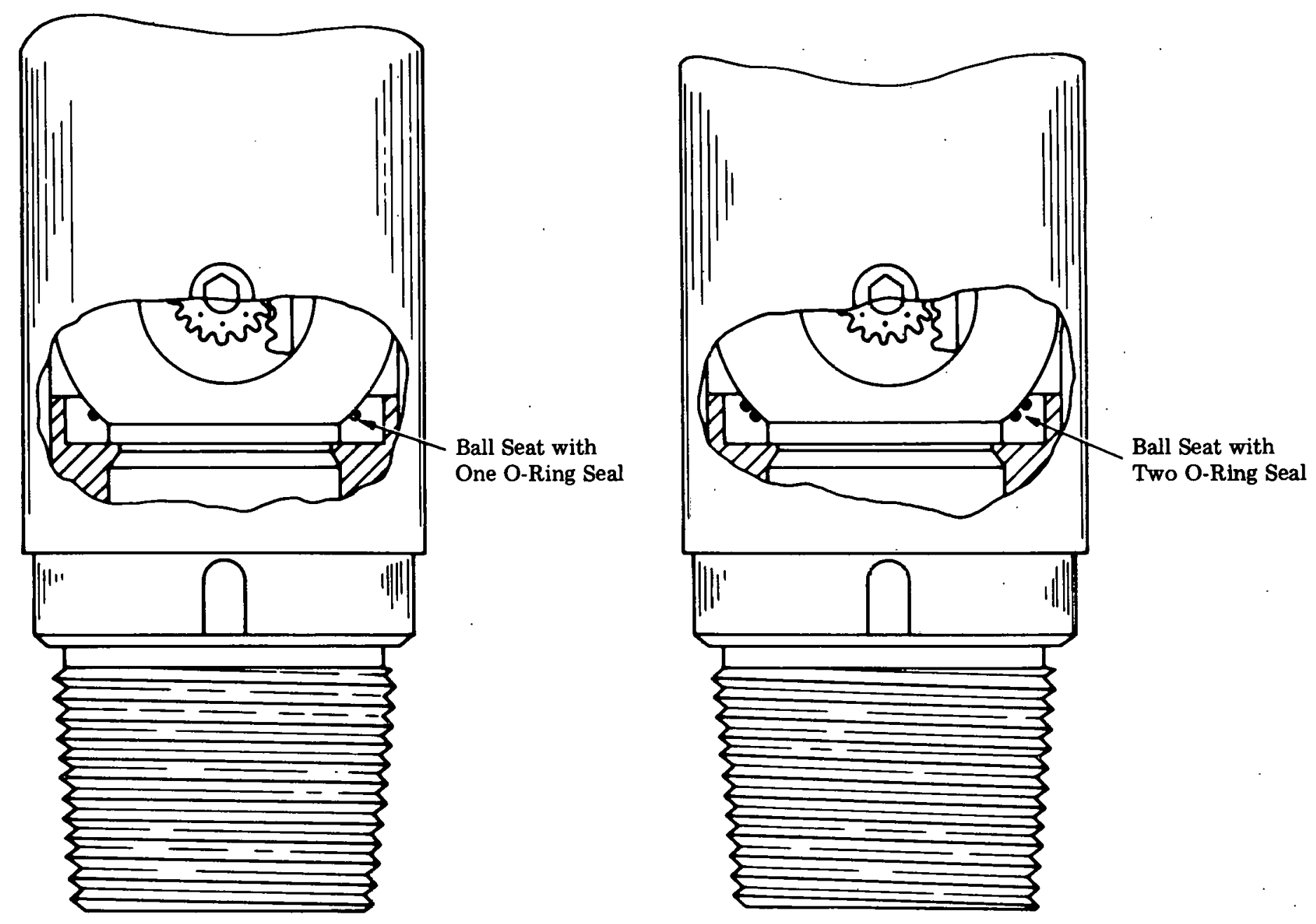

Figure 4-1 New "O" Ring Configuration on the Ball Seal Area 


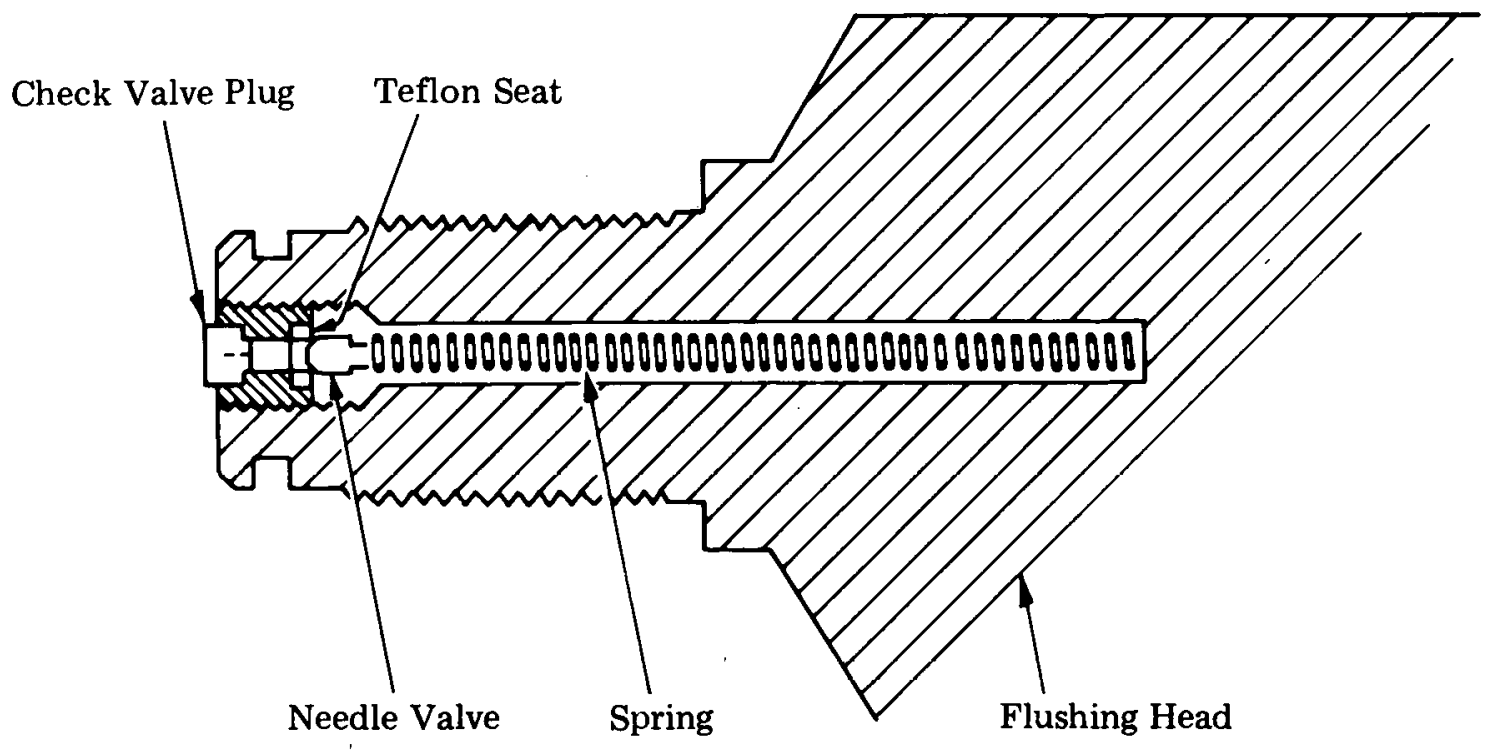

Figure 4-2 Flushing Head Check Valve

\subsubsection{Core Fluid Tests}

Work is continuing at Sandia on the low-invasion fluid testing equipment to include a dynamic filtration testing capability.

\subsubsection{Bit Design and Fabrication}

Since introduction of the diamond compax core bit at Denver City, Texas, in July, 1979, more than 120 pressure coring runs have been completed. Most of the coring has been in the Denver City area but other areas have included a Virginia coal seam, the Rainbow Lake area of Canada and other Permian Basin areas.

Since bit and barrel improvements have been made under the DOE program, the successful pressure core retrieval has increased from 75 percent in 1978 to the present 90 percent.

\subsubsection{Polycrystalline Diamond Core Bit Tests}

Test results of the improved pressure coring bits and low-invasion fluid will be analyzed when Core Laboratories' analysis of the cores cut by Texas Pacific and Gruy Federal at Denver City, Texas, becomes available. The results are expected by mid-January, 1980 . 


\subsubsection{Logging Studies}

\subsubsection{Interface Conductivity Effects on Electric Logging}

Over 60 core samples from five wells within the WGSP area have been analyzed for cation exchange capacity (CEC), gamma ray count (potassium-40, uranium and thorium), mineral content, and surface area. There are three general trends.

- CEC versus Surface Area: CECs were determined by the standard ammonium acetate technique ( $\mathrm{pH} 7.0$ ). Surface areas were measured via argon adsorption onto samples with particle sizes between 5 and 10 mesh, outgassed at $100^{\circ} \mathrm{C}$. The slopes of the CEC versus surface area plots are given in Table 4-1. If there is to be a strong, predictable correlation between CEC and the surface area of a sample, these slopes should be the same regardless of the clay type. However, the slope for samples from the Pacific Transmission Supply well is considerably greater than that for the others. The other wells have a mean slope of $17 \dot{5}+28$ $\mathrm{m}^{2} / \mathrm{meq}$, and slope of the Pacific Transmission well is 5.9 standard deviations greater. The correlation coefficient for the data from the PTS well is 0.94 . This anomaly will be interpreted when the remainder of the data are analyzed.

- Measured CEC (ammonium acetate technique) versus Calculated CEC (from clay analysis): Typical values of the $\mathrm{CEC} / \mathrm{g}$ for various constituent clays were used to calculate the CEC of each sample. As seen in Table 4-2, the ratios of the calculated-to-measured CEC are not in unity. The samples from the J. J. C. Paine well were higher in montmorillonite than any other well, indicating that the low ratio for this well may be due to an underestimate in the montmorillonite $\mathrm{CEC} / \mathrm{g}$ value. An overestimate of the CEC/g values for the low-CEC clays could explain the high ratios for the remaining wells. Since the CEC/g values for clay types are ranges, the CEC and clay analysis data can be used to calculate the best CEC/g values for the various constituent clays found in this geographic region.

When the measured and calculated CEC values are plotted against each other (measured CEC on the abscissa), a slope and intercept of 0.70 and $0.016 \mathrm{meg} / \mathrm{g}$, respectively, are obtained. This also indicates that the typical literature values of the CEC/g for the various clays need to be modified to predict CEC values in this region.

- CEC Versus the Potassium-40 Natural Gamma Count Rate: A summary of the slopes (pico curies/meq) for the five wells is given in Table 4-3. Correlation for the J. J. C. Paine, PTS and Twin Arrow data is poor. It is known that the PTS and Twin Arrow wells contained $\mathrm{KCl}$ water at the time the gamma ray logs were run. This indicates that the wells could have been drilled with a $\mathrm{KCl}$-based fluid which might have exposed the core material to $\mathrm{KCl}$ during the coring process. This might cause the potassium- 40 count rate not to be indicative of the clay present. The mean slope with $(345 \pm 163$ pico curies/meq) or without ( $338 \pm 20$ pico curies/ meq) the CIGE and J. J. C. Paine data is about the same, although the standard deviations of the two means are different. Unfortunately, the natural potassium40 gamma count rate from cores (or the adjacent formation) can be altered significantly by invasion. 


\begin{tabular}{lcc}
\hline \multicolumn{1}{c}{ Table 4-1 } & $\begin{array}{l}\text { Slopes of CEC Versus Surface Area Dala } \\
\text { For Several Wells Within the WGSP Area }\end{array}$ \\
\hline \multicolumn{1}{c}{ Well } & $\begin{array}{l}\text { Slope* } \\
\mathrm{m}^{2} / \mathrm{meq}\end{array}$ & No. of Data \\
\hline $\begin{array}{l}\text { Mobil } \\
\text { PCU F31-13G }\end{array}$ & 140 & 4 \\
$\begin{array}{l}\text { Joseph J. C. Paine } \\
\text { 1-0296 Federal }\end{array}$ & 174 & 12 \\
$\begin{array}{l}\text { Twin Arrow } \\
\text { C\&K 4-14X }\end{array}$ & 207 & 19 \\
$\begin{array}{l}\text { Pacific Transmission Supply } \\
\text { 24-19 Federal }\end{array}$ & 339 & 13 \\
CIGE & & \\
21-15-10-22 & 181 & 5 \\
\hline
\end{tabular}

* Through origin.

Table 4-2 Comparison of Measured and Calculated CEC

\begin{tabular}{lcccc}
\hline \multicolumn{1}{c}{ Well } & $\begin{array}{c}\text { Measured } \\
\text { CEC } \\
\text { Ave, meq/q }\end{array}$ & $\begin{array}{c}\text { Calculated } \\
\text { CEC }{ }^{*} \\
\text { Ave, meq/q }\end{array}$ & $\begin{array}{c}\text { No. } \\
\text { of } \\
\text { Data }\end{array}$ & $\begin{array}{c}\text { Calc. CEC } \\
\text { Meas. CEC }\end{array}$ \\
\hline $\begin{array}{l}\text { Mobil } \\
\text { PCU F31-13G }\end{array}$ & .0266 & .0402 & 4 & 1.51 \\
$\begin{array}{l}\text { J. J. C. Paine } \\
\text { 1-0296 }\end{array}$ & .0918 & .0773 & 9 & 0.84 \\
$\begin{array}{l}\text { Twin Arrow } \\
\text { C\&K 4-14X }\end{array}$ & .0226 & .0325 & 21 & 1.44 \\
$\begin{array}{l}\text { PTS } \\
\text { 24-19 Federal }\end{array}$ & .0190 & .0308 & 13 & 1.62 \\
CIGE & & $\ddots$ & & \\
21-15-10-22 & .0106 & .0265 & 1 & 2.50 \\
\hline
\end{tabular}

* From ammonium acetate techmique, pH 7.0

** Calculated from clay analysis and typical values of $\mathrm{CEC} / \mathrm{g}$ for various clays (literature values). 


\begin{tabular}{lcc}
\hline \multicolumn{1}{c}{ Table 4-3 } & $\begin{array}{l}\text { Slopes of the CEC Versus the Potassium-40 } \\
\text { Natural Gamma Count Rate }\end{array}$ \\
\hline \multicolumn{1}{c}{ Well } & $\begin{array}{c}\text { Slope } \\
\text { pCuries/meq }\end{array}$ & $\begin{array}{r}\text { No. of } \\
\text { samples }\end{array}$ \\
\hline $\begin{array}{l}\text { Mobil } \\
\text { PCU F31-13G }\end{array}$ & 323 & 3 \\
$\begin{array}{l}\text { J. J. C. Paine } \\
\text { 1-0296 Federal } \\
\text { Twin Arrow } \\
\text { C\&K 4-14X }\end{array}$ & 127 & 12 \\
$\begin{array}{l}\text { PTS } \\
\text { 24-19 Federal }\end{array}$ & $330^{*}$ & 22 \\
$\begin{array}{l}\text { CIGE } \\
\text { 21-15-10-22 }\end{array}$ & $361^{*}$ & 14 \\
\hline
\end{tabular}

* Drilled with $\mathrm{KCl}$ present.

Table 4-4 Effect of Net Confining Pressure on the Slope of Klinkenberg Plots and the Klinkenberg Constant, $b$

\begin{tabular}{ccc}
\hline & $\begin{array}{c}\text { Well: Mobil PCU F31-13G } \\
\text { Core Depth: } 8,498 \mathrm{ft} \\
\text { Core No: } 8498\end{array}$ \\
& & \\
Net Confining & $\begin{array}{c}\text { Slope (kLb), } \\
\text { (md) (atm) }\end{array}$ & $\begin{array}{c}\text { b, } \\
\text { Pressure, psi }\end{array}$ \\
\hline 120 & $2.87 \times 10^{-2}$ & 1.90 \\
2,000 & $6.50 \times 10^{-3}$ & 8.08 \\
3,000 & $4.44 \times 10^{-3}$ & 12.24 \\
3,500 & $3.82 \times 10^{-3}$ & 15.30 \\
4,000 & $3.22 \times 10^{-3}$ & 21.85 \\
4,250 & $2.61 \times 10^{-3}$ & 10.56 \\
\hline
\end{tabular}




\subsubsection{Mapping and Contouring Water Resistivities in Tight Western Gas Sands - Texas A\&M University}

In the September, 1979, Status Report, it was stated that all gas wells produce water which enters the well in the vapor phase. The relative amount of this is a function of formation temperature and pressure. The water condenses in the flow line and dilutes the formation water that enters the well. Although produced water would not be expected to give true values of $R_{W}$, the chemical analysis of this water may be useful.

Using the fact that the relative concentrations of the various ions are not changed by dilution, the self potential which would be generated by contact of this fluid with the mud filtrate across a shale boundary will be calculated. This will be done by use of Alger's conversion $^{1}$ of the ion content to an equivalent sodium chloride content. A comparison of this calculated SP with the SP observed on the electric log will reveal the extent to which the formation water was diluted. Then, from the corrected value of the ionic content of the formation water, a reliable value of the resistivity will be calculated. Alger's resistivity corrections based on composition will be applied.

A search for reliable formation water data is in progress. Analyses of waters obtained from 25 producing wells are available. Electric logs from these wells will be obtained from the Petroleum Information Corporation and the calculation of formation water resistivities will commence.

\subsubsection{In Situ Permeability}

\subsubsection{Measurement of Formation Characteristics for Western Tight Sands - Institute of Gas Technology}

In an effort to further understand the effect of confining pressure on tight sandstone permeability, experiments were conducted on core No. 8498 from the Mobil PCU F31-13G well, Piceance Basin. In these experiments, the effect of pore pressure was evaluated at different net confining pressures. Net confining pressures ranged from 120 psi to 4,250 psi. A straight line relating measured permeability with reciprocal mean pore pressure was obtained at each net confining pressure. The slope of this line and the Klinkenberg constant, $b$, at each confining pressure are shown in Table 4-4. The slope of the line, which is a measure of the effect of pore pressure on gas permeability, decreases as net confining pressure increases. At a net confining pressure of 4,250 psi, the slope is only about 9 percent of the slope at $120 \mathrm{psi}$. The constant, $\mathrm{b}$, increases with increasing net confining pressures up to 4,000 psi. A further increase in net confining pressure up to 4,250 psi resulted in a decrease in its value.

1 Alger, R.P., "Interpretation of Electric Logs in Fresh Water Wells in Unconsolidated Formations," Schlumberger Well Surveying Corporation in-house publication. 


\begin{tabular}{|c|c|c|c|c|c|c|}
\hline \multirow[t]{2}{*}{ Table 4-5 } & \multicolumn{6}{|c|}{$\begin{array}{l}\text { Comparison of Measurements on the Effect } \\
\text { of Confining Pressure on Permeability }\end{array}$} \\
\hline & \multicolumn{5}{|c|}{$\begin{array}{l}\text { Well: Mobil PCU F31-13G } \\
\text { Core Depth: } 8,498 \mathrm{ft} \\
\text { Core No. } 8498\end{array}$} & \\
\hline Net Confining Pressu & e,psi & & 1,000 & 2,000 & 3,000 & 4,000 \\
\hline \multirow{2}{*}{\multicolumn{2}{|c|}{ Percent Initial Permeability }} & 1 & 26.6 & 13.1 & 8.2 & 5.5 \\
\hline & & $\mathbf{2}$ & 34.4 & 23.0 & 13.3 & 8.9 \\
\hline
\end{tabular}

1: Current measurements.

2: Results reported by Byrnes et al.

Initial permeability $=0.021 \mathrm{md}$ for both 1 and 2 at net confining pressure $=120 \mathrm{psi}$ and mean pore pressure $=34.7 \mathrm{psia}$.

Table 4-6 Whole Core Analysis Compared to Plug Analysis on CIGE Natural Buttes No. 21 Well

\begin{tabular}{cccc}
\hline Depth, ft & Zone & $\Phi$ Whole core, percent & Ф plug, percent \\
\hline $4,464.0$ & B & 1.50 & 4.62 \\
$8,437.0$ & I & 8.10 & 8.66 \\
$4,458.5$ & B & 2.59 & 4.26 \\
$4,442.0$ & - & 1.86 & N.P. \\
$4,443.0$ & - & 1.39 & N.P. \\
$4,463.0$ & B & 2.37 & 4.26 \\
\hline
\end{tabular}

N.P. $=$ No plug taken from this core

$\Phi$ plug $=$ Average plug porosity for that zone

Comparison of these results with previous measurements ${ }^{2}$ indicates that the effect of net confining pressure is more pronounced now than it was earlier. This is probably due to the various stress cycles which the core has been subjected to and the fluids it has been exposed to in between the measurements. To facilitate comparison, Table 4-5 shows the results of both experimental measurements.

2 Byrnes, A.P. et al., "Effect of Pressure and Water Saturation on Permeability of Western Tight Sandstones." Presented at the Fifth Annual DOE Symposium on Enhanced Oil and Gas Recovery and Improved Drilling Technology, Tulsa, Oklahoma, August 22-24, 1979. 


\subsubsection{Permeability Measurements of Interbedding Material - LLL}

The hydraulic portion of the apparatus is nearly complete. The total instrumentation package is undergoing final assembly and debugging. Connecting the cable to the hydraulic system should begin about the end of February.

\subsubsection{Advanced Logging Techniques and Interpretation}

\subsubsection{Dielectric Constant Measurement for Formation Evaluation}

An experimental procedure using the Anyoe voltage standing wave ratio bridge and the new sample holder has been defined. The procedure was tested on an electrical component model for a core sample, and the results show good accuracy and reliability. Tests show that with this apparatus measurements can be made from $500 \mathrm{kHz}$ to $30 \mathrm{MHz}$. This frequency range includes a large portion of the practical range for a dielectric constant logging tool.

\subsubsection{Developments and Applications of a Wide Band Laboratory Dielectric Constant Measurement System - Colorado School of Mines}

This study is to develop laboratory technology which can be used to minimize uncertainties now present in formation analysis using dielectric constant logs.

Laboratory experiments conducted for the purpose of calibrating existing bridges indicated a necessity for sample shielding. It was also apparent that guard rings have to be larger in area. In the modified version, shielding will be performed by enclosing the sample holder in a metal jacket, which will be connected to the bridge ground. The sample compartment will be designed to hold samples $2.25 \mathrm{in}$. in diameter and 0.25 in. thick. The smaller ratio of sample thickness to diameter will improve the accuracy of measurements.

Construction of a laser mechanical beam exterior access shutter and integration of the pulsing capability in the laser experiments have been completed.

Sample preparation is still underway. Two bridges have been tested and adjusted for the first phase of this project. Measurements of capacitance using the 716-C General Radio Bridge has been conducted on synthetic sandstone samples (room dry). Measurements of the capacitance and dissipation factor (conductance) on the same samples have been made using a General Radio Bridge 1615-A. Results of these measurements indicate that the 1615-A bridge is more precise and measurements are easy to carry out. Therefore, the GR 1615-A bridge will be utilized in low frequency range measurements.

For the intermediate frequency range $(05-50 \mathrm{MHz})$, a GR 1606 bridge will be obtained. An oscillator (GR 1211-B) has been acquired and will be used as a generator for the 1606 bridge. 


\subsubsection{Study of Sonic, Neutron and Density Logging of Low Permeability Gas Sands - Texas A\&M University}

Whole core analysis continued on the Natural Buttes Unit No. 21 (CIGE 21) core. Parts of the core are still in the process of extraction. The cores which have been extracted and dried are being measured for porosity by the saturation method, using kerosene as the saturation fluid. This process will continue until all parts of the NBU No. 21 core have been analyzed. The results compared to the average plug porosity for the zone indicate that an average core porosity is needed for the entire zone before good comparisons can be made. Results obtained so far are shown in Table 4-6.

\subsubsection{Rock-Fluid Interaction}

\subsubsection{Threshold Fluid Flow Pressure of Tight Cores}

The purpose of this work was to determine a direct method for measuring gas drive pressures required to overcome water blocks in well bores or fractures due to drilling or frac fluids. According to Holditch (see Section 2.2.3 Articles and Publications), this is the limiting criterion for production. It appears that the pressure required to overcome core resistance may be measured by applying an increasing gas pressure to a saturated core and measuring the pressure of initial flow movement. The pressurized tube was liquid filled to ensure complete core saturation after fluid flow through the core.

For these tests, a 2 percent $\mathrm{KCl}$ brine was used as a saturating fluid. Confining pressures were maintained for at least $2 \mathrm{hrs}$ for sample stabilization before testing. Gas pressures were increased by 5 to 20 psi increments until fluid movement was obtained. Although data for samples tested (see Table 4-7) do not indicate a conclusive trend, lower permeability samples show increased pressure resistance with higher overburden pressures; whereas, high permeability samples do not indicate a trend. This work will continue using lower permeability samples. Drilling or fracturing fluids may be more appropriate if this technique proves to be useful.

\subsubsection{Proppant Embedment}

To better understand the effects of proppant size and formation hardness for hydraulic fracturing effectiveness, the previous proppant embedment work is being extended to include 20-40 and 40-60 mesh sintered bauxite, and formations of varying hardness. Preliminary indications are that the embedment of 12-20 mesh sintered bauxite into grey berea is considerably less than into the tight sandstone core from Pacific Transmission Supply No. 24-19 Federal well, (5,171 ft, Mesaverde Group) previously reported. The hardness (Rockwell B scale) of this berea is only about 40 percent that of the tight sandstone core. Even though the berea is considerably softer, it offers better proppant support, due to the relative elasticity and mechanical strength of the cementing material. Although cementing material in the berea is stronger (better proppant support), its elasticity is considerably less (more brittle), giving a lower Rockwell hardness. 
Table 4-7 PTS No. 24-19 Cores: Klinkenberg Permeability at 225 psi O.B.

Overburden pressure, psi

Initial flow pressure, psi

\begin{tabular}{|c|c|c|}
\hline & Sample $5120.7(26 \mu d)$ & \\
\hline $\begin{array}{r}600 \\
1,300 \\
2,300 \\
4,100\end{array}$ & & $\begin{array}{l}260 \\
260 \\
300 \\
240\end{array}$ \\
\hline \multicolumn{3}{|c|}{ Sample $5196.5(115 \mu \mathrm{d})$} \\
\hline $\begin{array}{r}200 \\
500 \\
1,000 \\
2,000 \\
2,900\end{array}$ & . & $\begin{array}{l}170 \\
180 \\
200 \\
230 \\
250\end{array}$ \\
\hline \multicolumn{3}{|c|}{ Sample 5172.3A $(132 \mu d)$} \\
\hline $\begin{array}{r}600 \\
1,300 \\
2,300 \\
4,200\end{array}$ & & $\begin{array}{l}35 \\
50 \\
40 \\
45\end{array}$ \\
\hline \multicolumn{3}{|c|}{ Sample 5204.8A $(147.5 \mu \mathrm{d})$} \\
\hline $\begin{array}{r}500 \\
1,200 \\
2,300 \\
4,200\end{array}$ & & $\begin{array}{l}25 \\
20 \\
15 \\
15\end{array}$ \\
\hline & Sample 5122.7A (415 $\mu \mathrm{d})$ & \\
\hline $\begin{array}{r}500 \\
1,200 \\
2,300 \\
4,200\end{array}$ & & $\begin{array}{l}20 \\
15 \\
15 \\
15\end{array}$ \\
\hline
\end{tabular}




\subsubsection{Schedule Status}

Figure 4-3 is a milestone chart depicting BETC WGSP progress.

\subsection{GAS RESEARCH INSTITUTE}

\subsubsection{Hydraulic Fracture and Testing of Rio Blanco Natural Gas Company No. 397-19-1 Government well, Rio Blanco County, Colorado}

An agreement was rcached to cancel further work under the subcontract.

\subsubsection{Evaluation of Seismic Data for Detailed Stratigraphic Studies of Lenticular Sands}

Field activities at Site No. 1 (Bryson Canyon) were completed by the end of December. Early tests involving shooting primacord on conspicuous sand channel outcrops were also completed. The top of the survey site was recorded to provide information on travel times to the channels plus frequency, velocity, and attenuation characteristics of the section. Additional shots were made in the now completed C K GeoEnergy Corehole DOE-GC-1 (see Section 3.6). These shots were made from 250-ft depth (hole blocked at this point) every 20 $\mathrm{ft}$ up to the surface. These will provide additional time ties to the sonic log taken, plus further velocity information. Upon completion of shooting elevations and locations of the shot/geophone stations, final processing of the Site No. 1 data will proceed.

\subsubsection{Coring and Logging of Rainbow Resources, Inc. No. 1-3 Federal Well, Sweetwater County, Wyoming}

Field work commenced December 29, funded jointly by GRI and the operator. Two Mesaverde cores were cut by December 31 from 12,398 to $12,497 \mathrm{ft}$, with full recovery. The operator resumed normal drilling at that point. Coring will resume below $12,600 \mathrm{ft}$ after the first of the year.

\subsection{LAWRENCE LIVERMORE LABORATORY}

\subsubsection{Theoretical Analysis}

As previously reported, a numerical technique has been developed to solve the equations for the shape of a symmetric crack for an arbitrary pressure distribution within the crack. Others $^{3}$ have reported analyses of the crack shape for various pressure distributions in the crack; however, the pressure distributions were proven low. A set of calculations has been completed where the pressure distribution in the crack was arbitrary and the pressure was not constant over the crack surface. For these preliminary calculations, a far field stress was not included but this should not cause any significant problems in further analyses. Inclusion of a far field stress is a linear superposition with the pressure in the crack.

3 Daneshy, A. A., "Opening of a Pressurized Fracture in an Elastic Medium," Petroleum Society of CIM, Paper No. 7616, June 1971. 


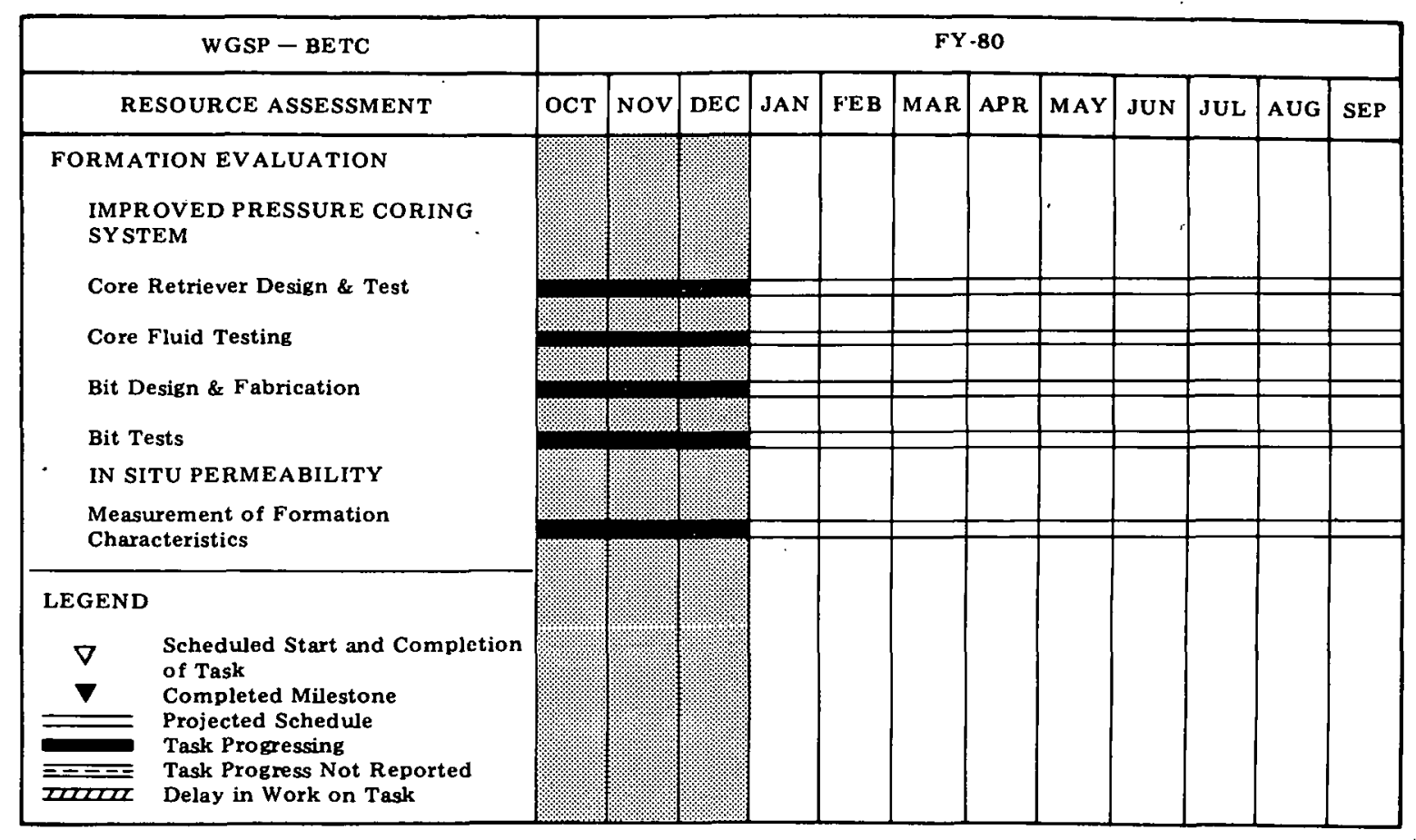

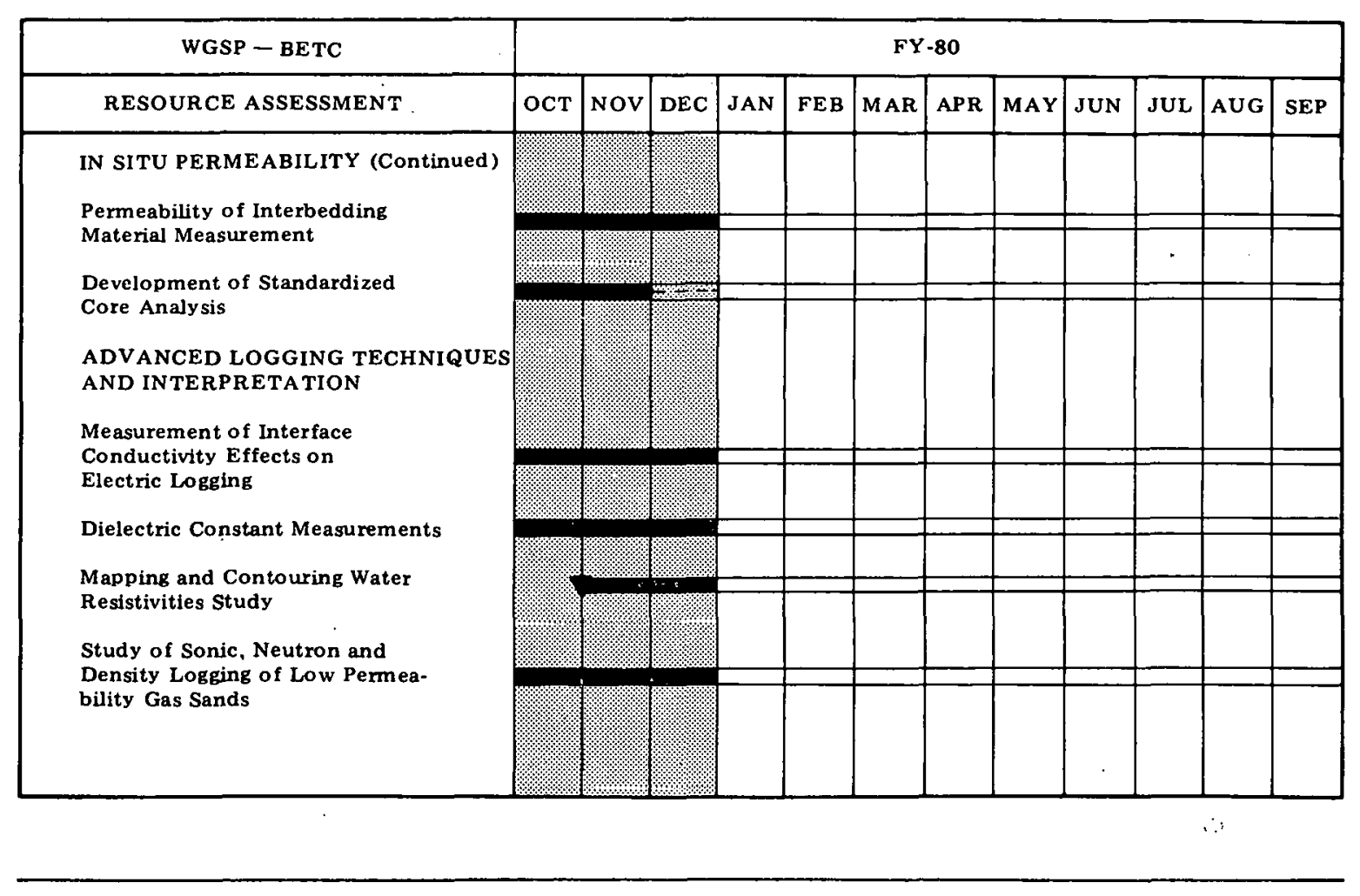

Figure 4-3 Milestone Chart-BETC 


\begin{tabular}{|c|c|c|c|c|c|c|c|c|c|c|c|c|}
\hline WGSP - BETC & \multicolumn{12}{|c|}{ FY-80 } \\
\hline RESOURCE ASSESSMENT & OCT & nov & DEC & JAN & F'EB & MAR & APR & MAY & JUN & JUL & AUG & SEP \\
\hline \multicolumn{13}{|l|}{$\begin{array}{l}\text { STIMULATION MECHANICS \& } \\
\text { METHODS }\end{array}$} \\
\hline \multicolumn{13}{|l|}{$\begin{array}{l}\text { RESERVOIR MODELING AND } \\
\text { STIMULATION }\end{array}$} \\
\hline \multicolumn{13}{|l|}{$\begin{array}{l}\text { Perform Analysis of MHF Test } \\
\text { Data and Engineering Studies }\end{array}$} \\
\hline \multicolumn{13}{|l|}{ ROCK-FLUID INTERACTION } \\
\hline \multicolumn{13}{|l|}{ Physical Measurements } \\
\hline \multicolumn{13}{|l|}{$\begin{array}{l}\text { PROPPANT AND PROPPANT } \\
\text { TRANSPORT }\end{array}$} \\
\hline \multicolumn{13}{|l|}{ Evaluation of Particle Transport } \\
\hline \multirow{2}{*}{\multicolumn{13}{|c|}{$\begin{array}{l}\text { Evaluation of Proppant Embed- } \\
\text { ment in Tight Gas Sands }\end{array}$}} \\
\hline & & & & & & & & & & & & \\
\hline \multicolumn{13}{|l|}{ Study of Proppant Settling } \\
\hline \multirow{2}{*}{\multicolumn{13}{|c|}{$\begin{array}{l}\text { Light Weight Proppant Feasi- } \\
\text { bility Study }\end{array}$}} \\
\hline & & & & & & & & & & & & \\
\hline
\end{tabular}

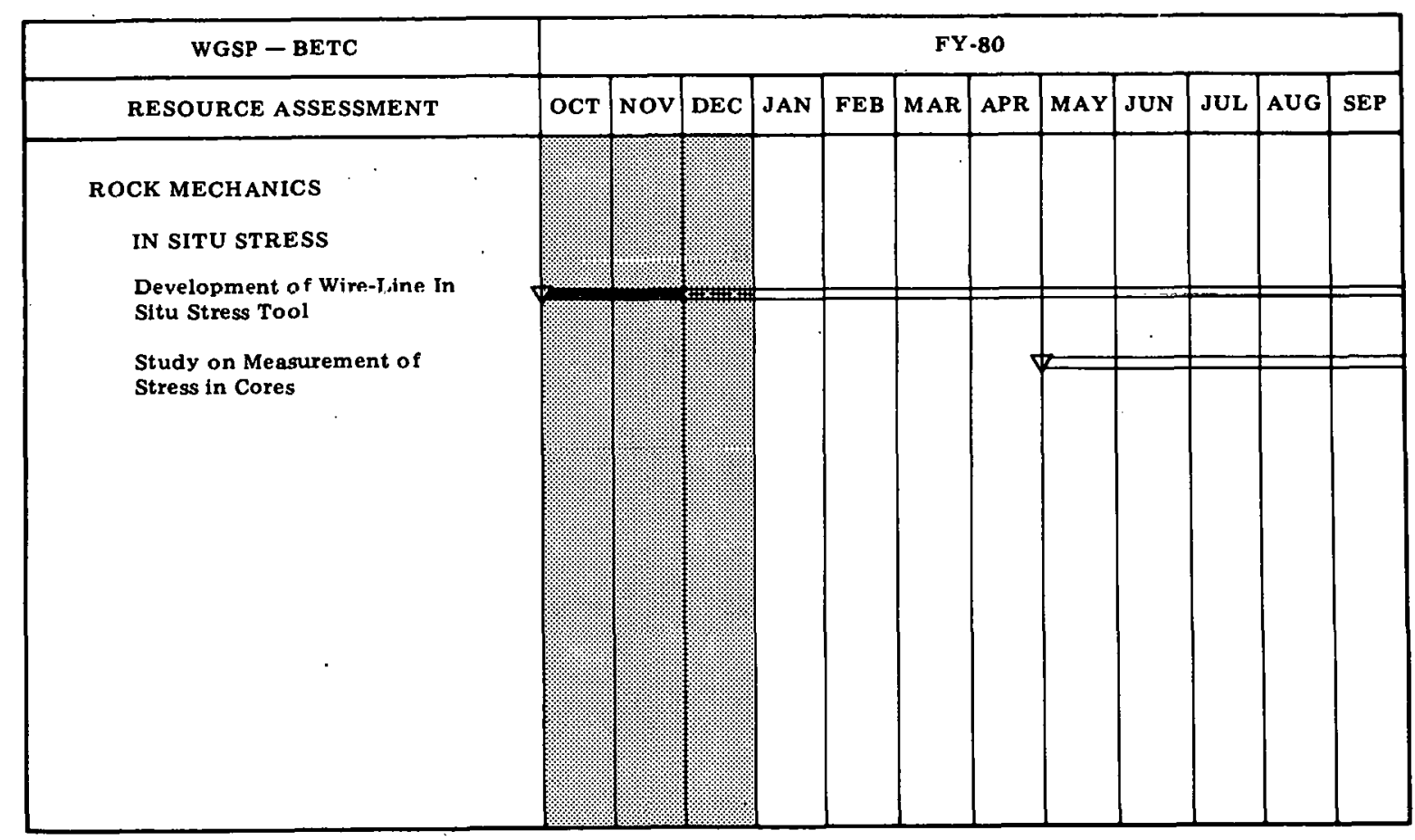

\section{Figure 4-3 Continued}


The boundary conditions for the three problems analyzed were:

$$
\begin{array}{lll}
\sigma_{\mathrm{yy}}=\mathrm{p}(\mathrm{x}), & \mathrm{y}=0 & |\mathrm{x}|<\mathrm{a} \\
\sigma_{\mathrm{xy}}=0, & \mathrm{y}=0 & \\
\mathrm{u}_{\mathrm{y}}=0, & \mathrm{y}=0 & |\mathrm{x}|>\mathrm{a}
\end{array}
$$

where $\mathrm{a}$ is the crack half length, $\sigma_{\mathrm{yy}}$ is the stress component normal to the two-dimensional crack axis, $\sigma_{x y}$ is the shear stress and $u_{y}$ is the displacement normal to the crack axis. In defining $p(x)$, it is convenient to define a variable $x_{1}$, which is a length bounded by a. For each pressure distribution four calculations were made corresponding to $\mathrm{x}_{1}=\mathrm{a}, .75 \mathrm{a}, .50 \mathrm{a}$, and .25a.

Figure 4-4 shows a portion of the crack shape in the quadrant $x \geq 0$ and $y \geq 0$ for the pressure distributions $p(x)=p_{0}$ for $-x_{1} \leq x \leq x_{1}$ and $p(x)=p_{0}$ for $a \geq|x| \geq x_{1}$. In this case when $x_{1}=a$, the crack shape is elliptic and as $x_{1}$ decreases to .25a, the crack shape displays a significant "hump" near the center. Additionally, the aperature at the crack center decreases by a factor of about 2 when comparing the aperature for $x_{1}=a$ and $x_{1}=.25 a$. Figure 4-5 displays the crack shape in the quadrant $\mathrm{x} \geq 0$ and $\mathrm{y} \geq 0$ for a parabolic distribution over a portion or all of the crack surface. Here $p(x)=p_{0} \sqrt{1-|x|} / x_{1}$ for $-x_{1} \leq x \leq$ $x_{1}$ and $p(x)=0$ for $a \geq x \geq x_{1}$. There is a "hump" at the crack center, but not quite as pronounced as the previous results. There is also a decrease of a factor of 2 in crack aperature when the crack is loaded over a quarter of its half length as compared to the load over the entire length. Figure 46 displays the crack shape in the quadrant $x \geq 0$ and $y \geq 0$. The pressure distribution in the crack for this case is $p(x)=p_{o}\left(1-|x| / x_{1}\right)$ and $p(x)=0$ for $a \geq x \geq x_{1}$. There are similar characteristics between the other two pressure distributions, although slope changes along the crack surface are not as pronounced.

When comparing the crack shapes for the three pressure distributions, the crack aperature decreases from the constant pressure to the parabolic to the triangular pressure distribution. This is to be expected since total load decreases in each case for a given $x_{1}$. It is also possible that when the pressure does not reach the crack tip, the flow characteristics of a viscous fluid can be influenced by the crack shape. This could also have a significant effect on the proppant deposition in the crack. The flow in the crack will be the subject of further analyses and the model used here will provide the boundary conditions for these flow calculations.

\subsubsection{Experimental Program}

\subsubsection{Crack Growth Across Unbonded Interfaces}

Experiments have been performed to evaluate several lubricants that will reduce the frictional properties of smooth, unbonded interfaces. Of the lubricants tested, the one which most significantly reduced the friction was a compound called "Hi-Temp C-100 Anti-Ball Lubricant." Friction experiments using the three block sandwich apparatus, were performed on blocks of Indiana limestone whose smooth interface surfaces had been coated with a thin layer of this lubricant. It was found that the relationship between the frictional and normal stresses across the interface could he represented by

$$
\mathrm{fr}=30+.125 \mathrm{~N}
$$




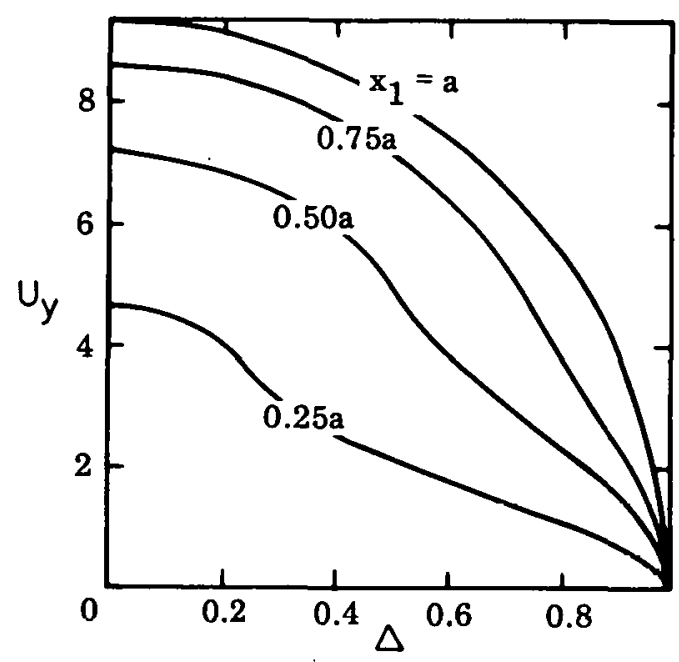

Figure 4-4 Crack shape for a constant pressure $p=p_{o}$ for $|x| \leq x_{1}$ and $p=0$ elsewhere in the crack. Note: the crack shape is only shown for $y \geq 0$ and $x \geq 0$.

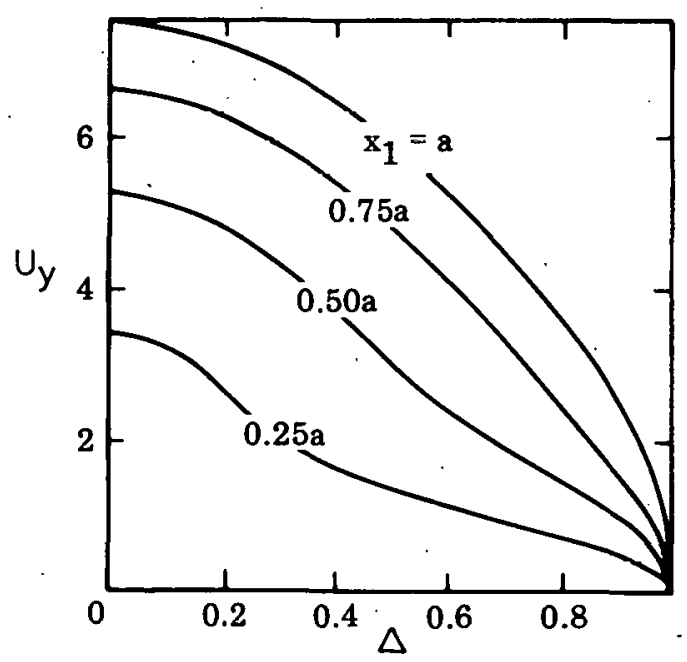

Figure 4-5 Crack shape for a parabolic pressure distribution, $p=p_{o}\left(\frac{\sqrt{1-|x|}}{x_{1}}\right)$ for $|x| \leq x_{1}$ and $p=0$ elsewhere. Note: the crack shape is only shown for $y \geq 0$ and $x \geq 0$.

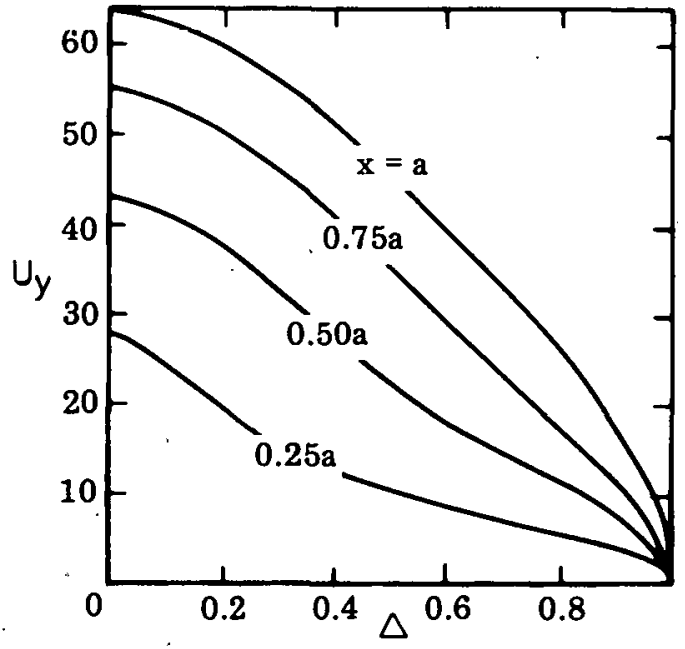

Figure 4-6 Crack shape for a triangular pressure distribution, $p=p_{0}\left(\frac{1-|x|}{x_{1}}\right)$ for

$|x| \leq x_{1}$ and $p=0$ elsewhere. Note: the crack shape is only shown for $y \geq 0$ and $x \geq 0$. 
where fr and $\mathrm{N}$ are the frictional and normal stresses, respectively, and all stresses are in psi. The corresponding relationship for smooth unlubricated surfaces is

$$
\mathrm{fr}=20+.51 \mathrm{~N} .
$$

Hydraulic fracture experiments were then performed to determine the threshold normal stress across an unbonded interface lubricated with $\mathrm{C}-100$. The threshold stress was found to be near 2,200 psi compared to 650 psi for the dry, unlubricated surface. These experiments on dry and lubricated unbonded interfaces indicate that the interface in limestone must be able to support a shear frictional stress in the range of 300 to 350 psi in order for a hydraulically driven crack to penetrate it.

\subsubsection{Rock Mechanics Measurements}

During December, measurements were made on the failure envelope of Wyoming Mesaverde sandstone loaded perpendicular to the bedding. The failure envelope study of this rock is complete and results will be forthcoming.

Data reduction of the pressure-volume measurements for Mesaverde shale from Rio Blanco County, Colorado, is nearly complete and these results are also forthcoming.

\subsubsection{Schedule Status}

Figure 4-7 is a milestone chart depicting the progresss of LLL within the WGSP.

\subsection{LOS ALAMOS SCIENTIFIC LABORATORY}

The purpose of this research is to develop methods to define fluid saturation, porosity, and permeability in Western gas sands as a function of in situ stress conditions. Results will then be correlated with nuclear magnetic resonance studies so that an improved downhole nuclear magnetic resonance tool can be designed.

Figure 4-8 is a milestone chart depicting LASL's WGSP status.

\subsection{SANDIA LABORATORIES}

\subsubsection{EGR Instrumentation and Diagnostic Program}

\subsubsection{Hydraulic Fracture Characterization}

The Shell Oil Company's fracturing experiment to be conducted near Lake Texoma, Texas, continues to be delayed. One of the planned zones for stimulation has been deleted from the experiment and the second zone is being evaluated. Plans still include coverage of the fracture with surface resistivity, borehole seismics (two holes) and surface tiltmeters. A tentative fracture date has been set for early February, 1980. 


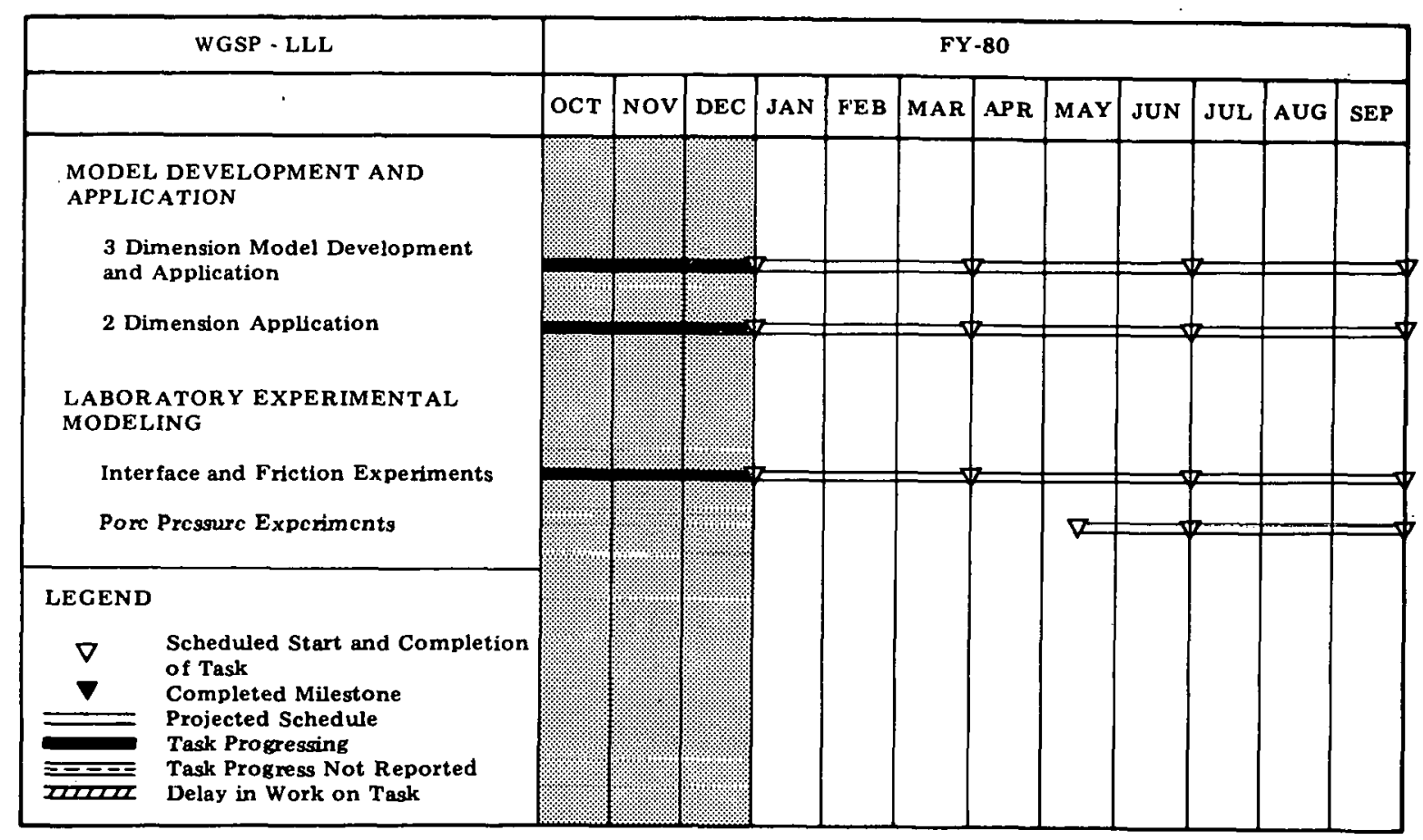

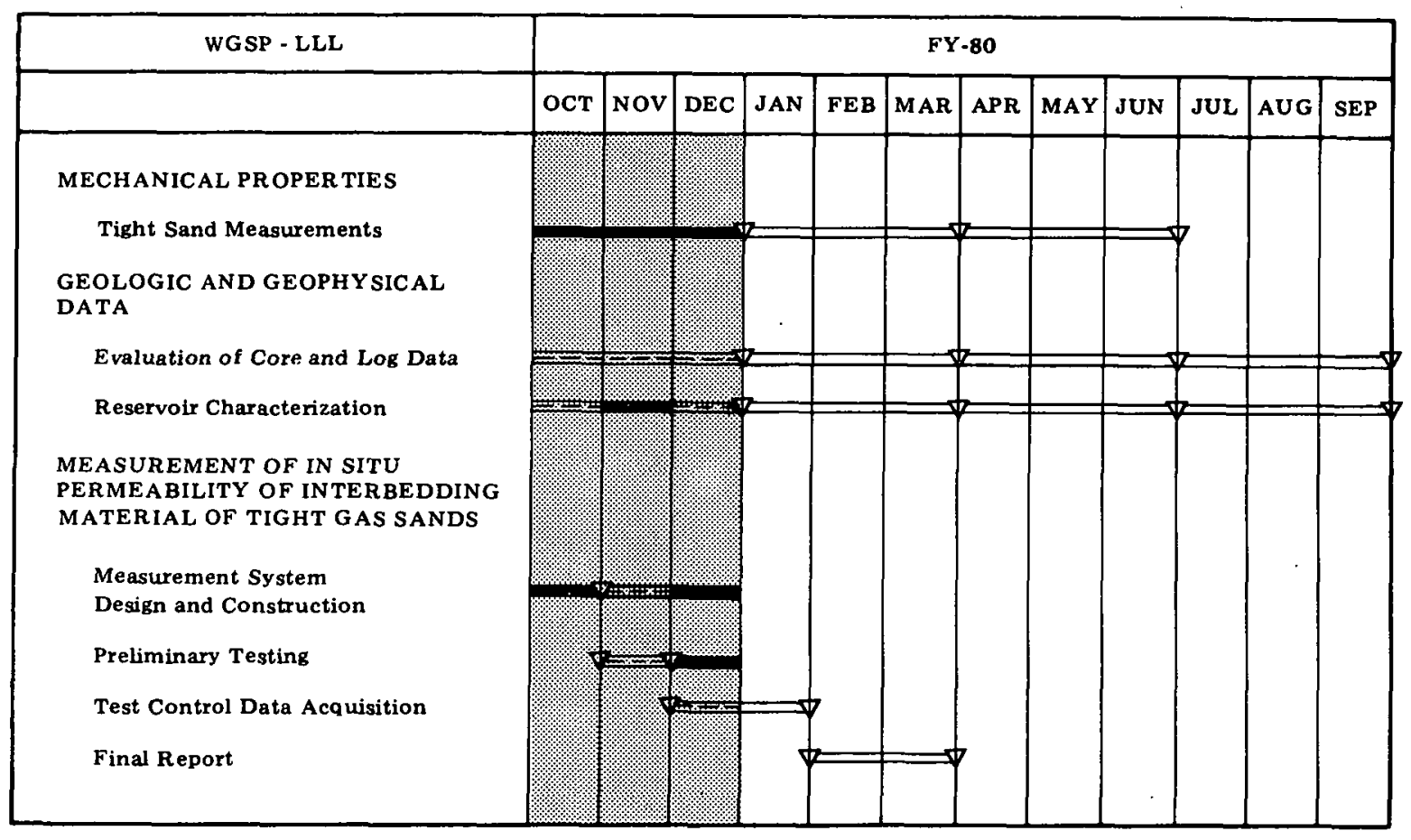

Figure 4-7 Milestone Chart - LLL 


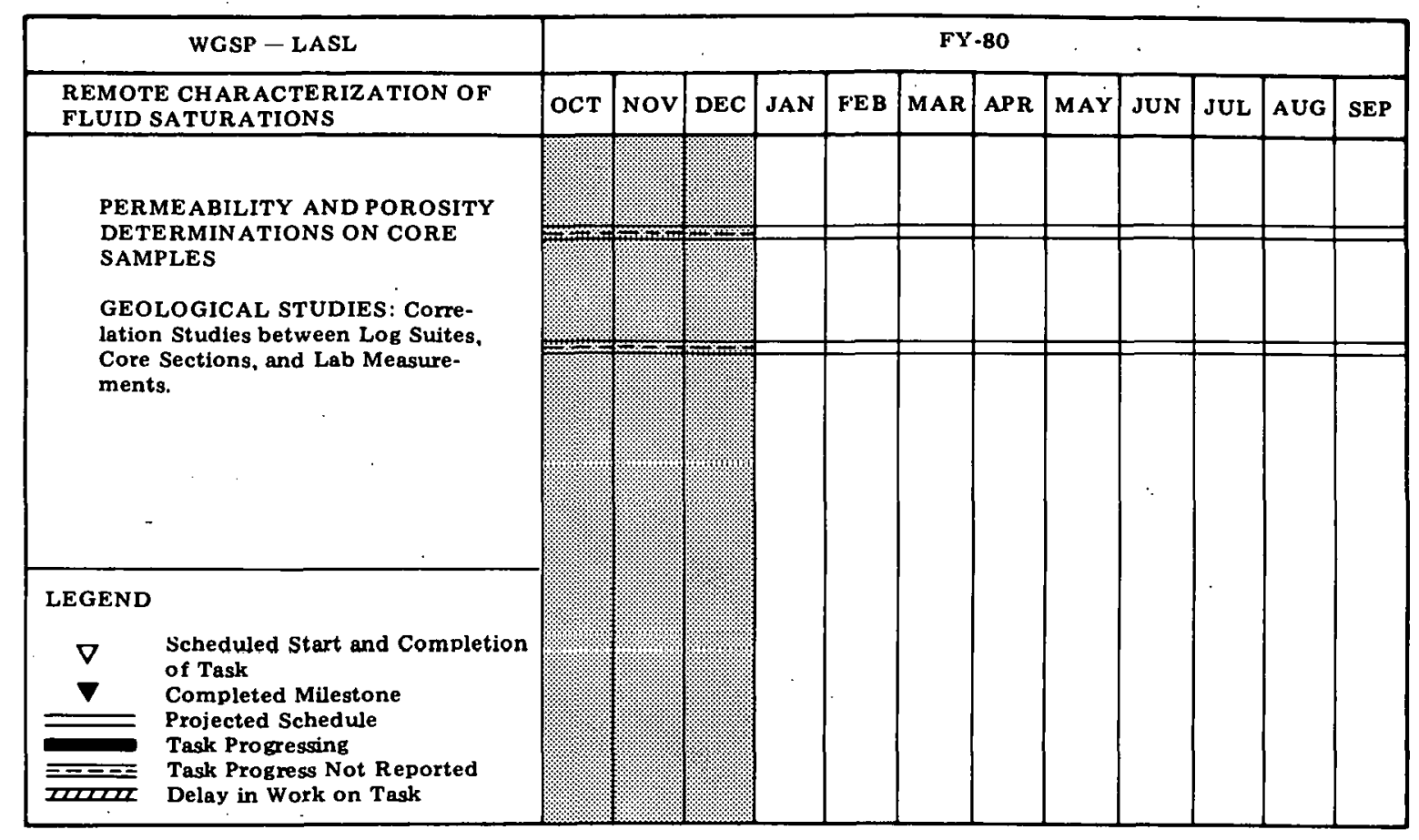

\begin{tabular}{|c|c|c|c|c|c|c|c|c|c|c|c|c|}
\hline \multirow{2}{*}{$\begin{array}{l}\text { WGSP-LASL } \\
\text { REMOTE CHARACTERIZATIONS OF } \\
\text { FLUID SATURATIONS }\end{array}$} & \multicolumn{12}{|c|}{ FY $=80$} \\
\hline & OCT & Nov & DEC & JAN & FEB & MAR & APR & MAY & JUN & JUL & AUG & SEP \\
\hline \multirow{2}{*}{\multicolumn{13}{|c|}{$\begin{array}{l}\text { NUCLEAR MAGNETIC RESO- } \\
\text { NANCE STUDIES }\end{array}$}} \\
\hline & & & & & & & & & & & & \\
\hline \multicolumn{13}{|l|}{ THEORETICAL STUDIES } \\
\hline \multicolumn{13}{|l|}{ Toroidal Magnetic Field } \\
\hline \multicolumn{13}{|l|}{ Signal Detection } \\
\hline \multirow{2}{*}{\multicolumn{13}{|c|}{$\begin{array}{l}\text { Reservoir Fluid Charac- } \\
\text { teristics by NMR }\end{array}$}} \\
\hline & & & & & & & & & & & & \\
\hline \multicolumn{13}{|l|}{ LABORATORY STUDIES } \\
\hline \multicolumn{13}{|l|}{$\begin{array}{l}\text { Feasibility of Remote NMR } \\
\text { Detection }\end{array}$} \\
\hline \multirow{3}{*}{\multicolumn{13}{|c|}{$\begin{array}{l}\text { Remote Detection of NMR } \\
\text { in Focused Toroidal Magnetic } \\
\text { Field }\end{array}$}} \\
\hline & & & & & & & & & & & & \\
\hline & & & & & & & & & & & & \\
\hline \multicolumn{13}{|l|}{ Remote NMR Signal } \\
\hline & & & & & & & & & & & & \\
\hline Reservoir Fluid NMR & & & & & & & & & & & & \\
\hline Characteristics & & & & & & & & & & & & \\
\hline
\end{tabular}

Figure 4-8 Milestone Chart - LASL 


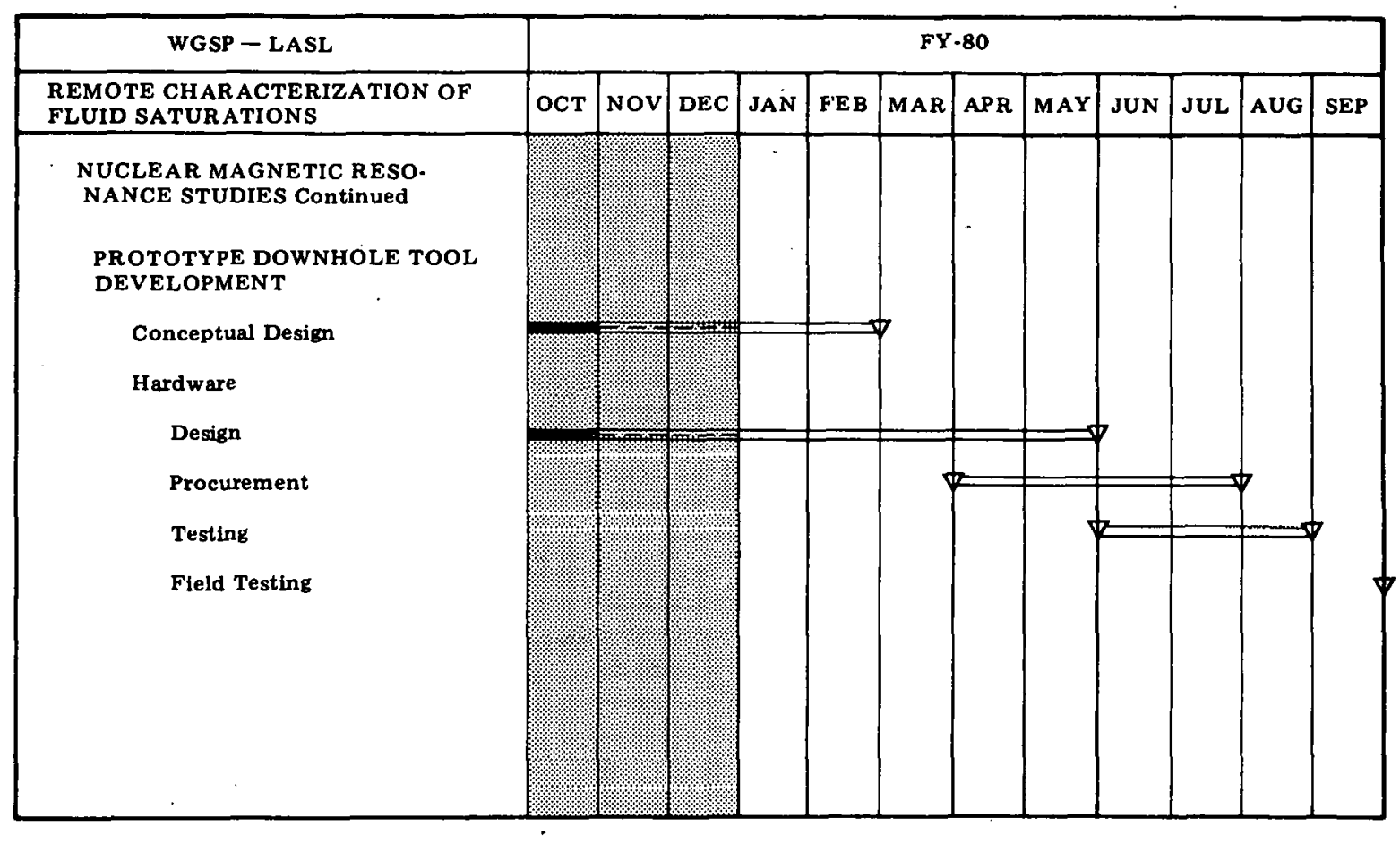

\section{Figure 4-8 Continued}

\subsubsection{Electrical Resistivities System}

A finite element solution to Laplace's equation is currently on the Sandia computers. This code will be used to model the potentials resulting from a current source embedded in an axisymmetric resistivity distribution. Model parameters (resistivities in each of the elements) will be adjusted automatically by a regression algorithm to minimize the difference between model predictions and measured potentials. The inverse problem will thus be solved by a series of iterations of the forward problem. The finite element code has the capability to handle large numbers of resistivity elements. Therefore, the effects of finite electrode dimensions and wellbore roughness should be possible to determine. A less complex algorithm will also be developed to permit some field reduction capability.

\subsubsection{Nuclear Magnetism Logging}

NMR testing and final core analyses are continuing by Chevron Research Laboratory on eleven cores from the Colorado Interstate Gas Exploration No. 21 well from northeast Uinta Basin. Initial core analysis was completed by a commercial laboratory. 


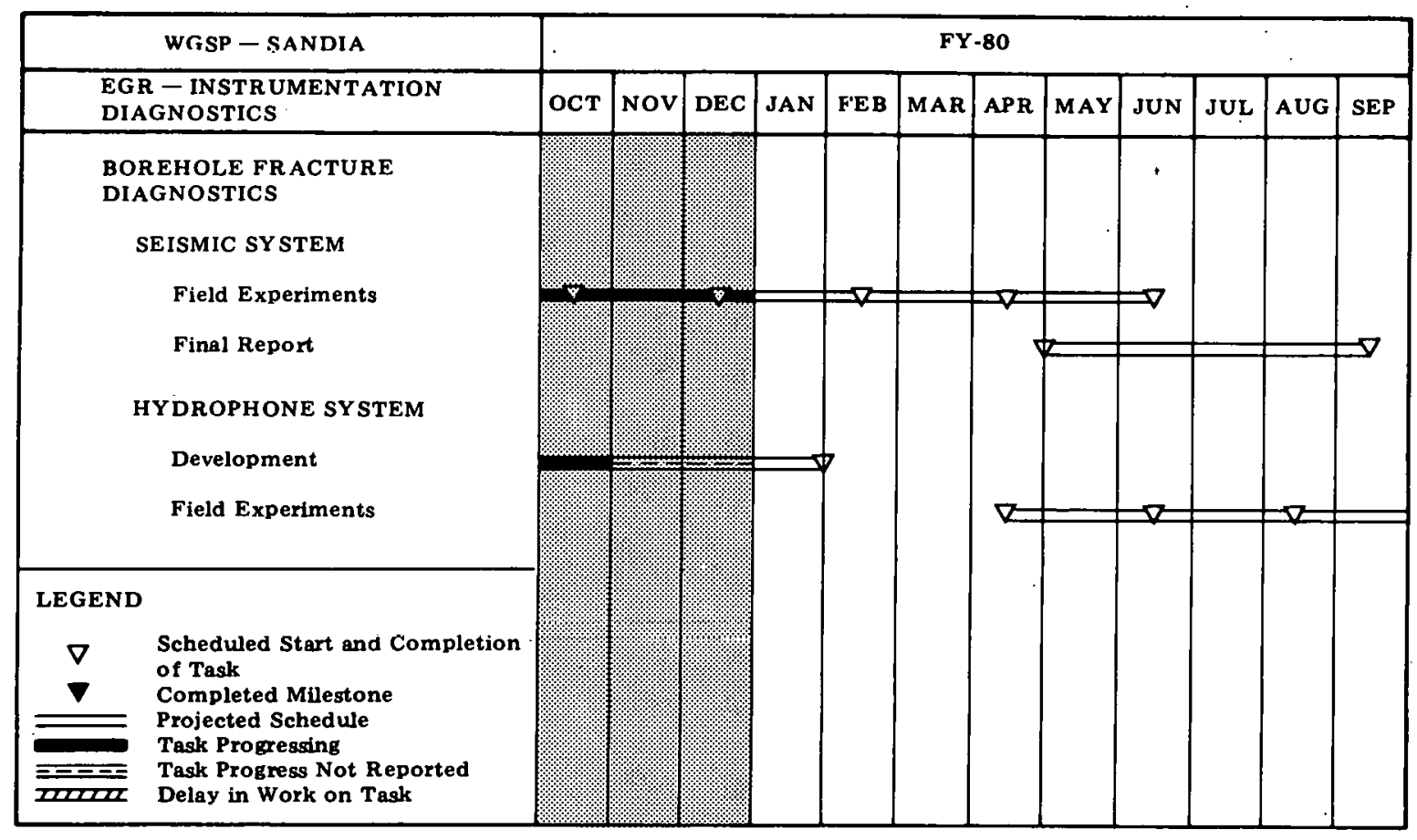

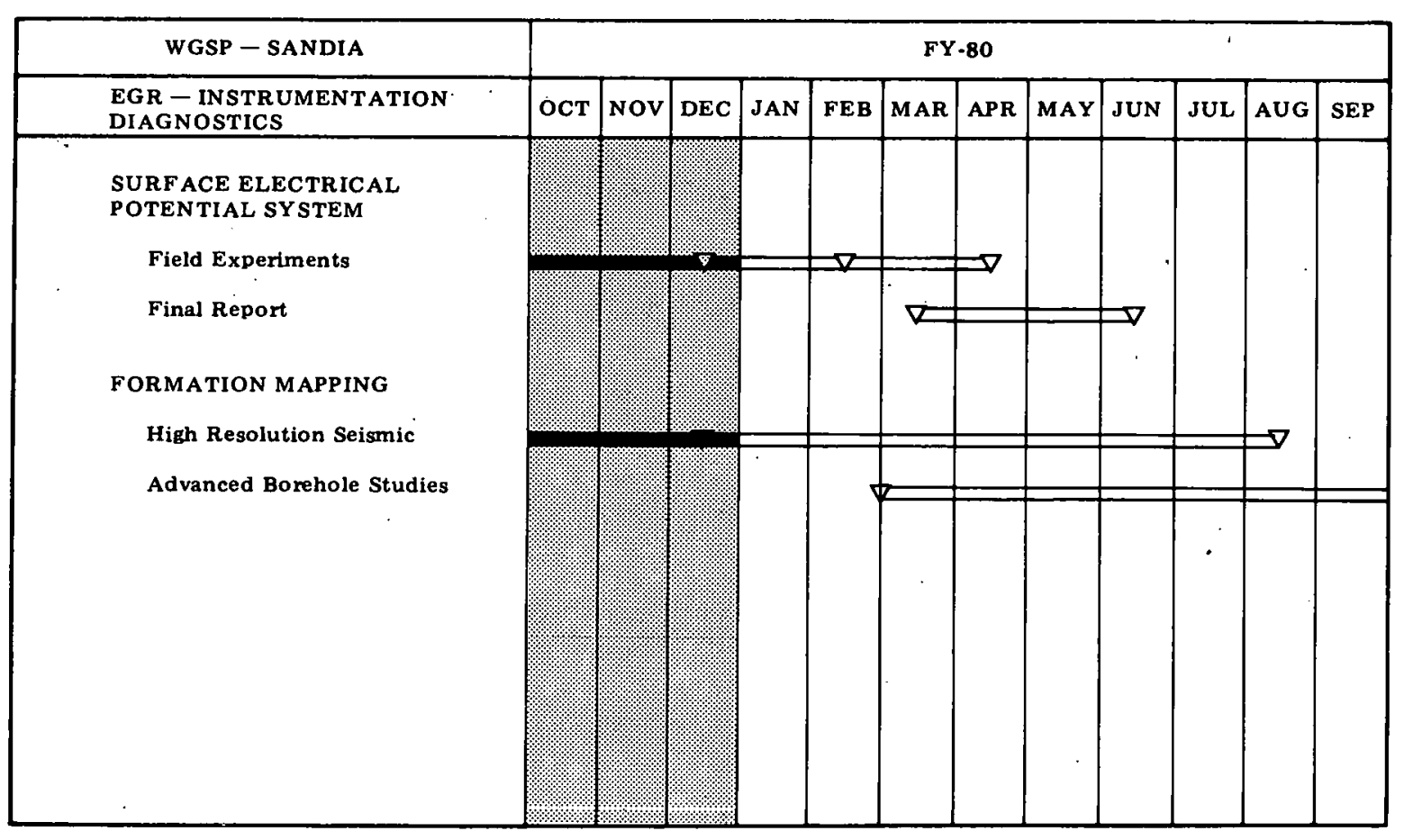

Figure 4-9 Milestone Chart - Sandia 


\begin{tabular}{|c|c|c|c|c|c|c|c|c|c|c|c|c|}
\hline WGSP - SANDIA & \multicolumn{12}{|c|}{ FY -80} \\
\hline $\begin{array}{l}\text { EGR - INSTUMENTATION } \\
\text { DIAGNOSTICS }\end{array}$ & OCT & NOV & DEC & JAN & F'E B & MAR & APR & MAY & JUN & JUL & AUG & SEP \\
\hline \multicolumn{13}{|l|}{$\begin{array}{l}\text { ELECTROMAGNETIC } \\
\text { IMPEDENCE SONDE }\end{array}$} \\
\hline \multicolumn{13}{|l|}{ Feasibility Study } \\
\hline $\begin{array}{c}\text { Geological Description } \\
\text { Prototype Development }\end{array}$ & & & & & & $\nabla$ & & & & & & \\
\hline $\begin{array}{l}\text { ELECTROPOTENTIAL } \\
\text { SONDE }\end{array}$ & & & & & & & & & & & & \\
\hline Feasibility Study & & $x=x$ & $1=$ & & & & & & & & & \\
\hline Parametric Description & & & & & & & $\nabla$ & & & & & \\
\hline Prototype Development & & & & & & & & & & & & \\
\hline . & & & & & & & & & & & & \\
\hline
\end{tabular}

Figure 4-9 Continued

\subsubsection{High Resolution Seismic Formation Mapping}

Topographic surveying at the Bryson Canyon site is complete. The seismic crew acquired a new recording system (TI-DFSV) which should improve recording capabilities. This instrument was installed and the crew began shooting early December. All field activities at Site No. 1 (Bryson Canyon) were completed by the end of December. (For more information, see Section 4.2.2 Evaluation of Seismic Data for Detailed Stratigraphic Studies of Lenticular Sands.)

\subsubsection{Electromagnetic Logging}

In December, the boundary value problem of a thin spheroidal shell (clay) surrounding a solid (pore fluid) inclusion was solved. It is expected that this will be a first-order approximation to the problem of modeling clays lining open pores.

Finite difference models can model a great number of material boundaries, e.g., cables, probe walls, borehole walls, invasion zones, etc. A difficulty with this type of modeling is that the grid size is finite. This means that an artificial outer boundary exists and this boundary can introduce nonphysical reflections which will be observed at receiver locations. Attempts were made to dampen these reflections, although there has been no success so far.

\subsubsection{Schedule Status}

Figure 4-9 depicts Sandia's progress in a WGSP milestone chart. 


\section{FIELD TESTS AND DEMONSTRATIONS}

\subsection{BACKGROUND}

Field tests are essential to verify the findings of laboratory tests and modeling studies. The field test and demonstration program involves cooperation between industry and government and also interacts geologic studies with laboratory research and development. The following projects are active in the WGSP:

- A dry gas injection experiment in the Wattenberg Field, Colorado, by Colorado Interstate Gas Company,

- MHF demonstrations by Gas Producing Enterprises in the Uinta Basin, Utah,

- MHF treatment of the Cotton Valley Limestone Formation in Limestone County, Texas, by Mitchell Energy Corporation,

- MHF demonstrations in the Piceance Basin, Colorado, by Mobil Research and Development Corporation and Rio Blanco Natural Gas Company, and

- A mineback testing program by Sandia Laboratories.

Table 5-1 summarizes completed and active WGSP MHF treatments. Progress of these projects is presented in the following sections. 
Table 5-1 MHF Contract Location and Frac Data

\begin{tabular}{|c|c|c|c|c|c|c|c|c|c|}
\hline $\begin{array}{c}\text { Company Basin \& } \\
\text { Formation }\end{array}$ & $\begin{array}{l}\text { Location } \\
\text { T/R/Sec }\end{array}$ & Well & $\begin{array}{c}\text { Interval } \\
\text { Fractured } \\
\text { ft }\end{array}$ & $\begin{array}{l}\text { Fracture } \\
\text { Date }\end{array}$ & $\begin{array}{l}\text { Fracture } \\
\text { Treatment } \\
\text { Lb of Sand }\end{array}$ & $\begin{array}{l}\text { Injected } \\
\text { Fluid } \\
10^{3} \mathrm{Gal}\end{array}$ & $\begin{array}{r}\text { Product } \\
\text { MC } \\
\text { Before }\end{array}$ & Rates & Ratio \\
\hline $\begin{array}{l}\text { AUSTR AL } \\
\text { Piceance, } \\
\text { Mesaverde }\end{array}$ & $\begin{array}{l}7 \mathrm{~S} / 94 \mathrm{~W} / \mathrm{Sec} 3 \\
\text { Garfield Cty. } \\
\text { Colorado }\end{array}$ & $\begin{array}{l}\text { Federal } \\
3-94\end{array}$ & $\begin{array}{l}6,198-6,333 \\
5,170-5,630\end{array}$ & $\begin{array}{l}8-13-76 \\
8-25-76\end{array}$ & $\begin{array}{l}420.000 \\
720.000\end{array}$ & $\begin{array}{l}226 \mathrm{Gel} \\
316 \mathrm{Gel}\end{array}$ & 35 & 62 & 1.8 \\
\hline $\begin{array}{l}\text { CONSORTIUM } \\
\text { MANAGED BY } \\
\text { CER CORPORATION } \\
\text { Piceance, Mesaverde }\end{array}$ & $\begin{array}{l}3 S / 98 W / \mathrm{Sec} 11 \\
\text { Rio Blanco Cty, } \\
\text { Colorado }\end{array}$ & R B-M HF - 3 & $\begin{array}{l}8,048-8,078 \\
7,760-7,864 \\
5,925-6,016 \\
5,851-5,869\end{array}$ & $\begin{array}{l}10-23-74 \\
05-02-75 \\
04-04-76 \\
11-U 3-76\end{array}$ & $\begin{array}{l}400,000 \\
880,000 \\
815,000 \\
448,000\end{array}$ & $\begin{array}{l}117 \mathrm{Gel} \\
285 \mathrm{Gel} \\
400 \mathrm{Gel} \\
228 \mathrm{Gel}\end{array}$ & $\begin{array}{l}60 \\
42 \\
57\end{array}$ & $\begin{array}{r}60 \\
40 \\
160 \\
70\end{array}$ & $\begin{array}{l}- \\
3.8 \\
1.2\end{array}$ \\
\hline $\begin{array}{l}\text { DALLAS } \\
\text { PRODUCTION } \\
\text { Fort Worth, } \\
\text { Bend Cong. }\end{array}$ & $\begin{array}{l}\text { Ben D. Smith } \\
\text { Survey A-779 } \\
\text { Wise Cly. } \\
\text { Texas }\end{array}$ & $\begin{array}{l}\text { Ferguson } \\
\text { A-1 }\end{array}$ & $5,957-6,794$ & $09-16-76$ & 506.0001 & $\begin{array}{l}139 \text { Foam } \\
198 \mathrm{Emul}\end{array}$ & 40 & 15 & - \\
\hline $\begin{array}{l}\text { EL PASO } \\
\text { NATURAL GAS } \\
\text { Northem Green River, } \\
\text { Fort Union }\end{array}$ & $\begin{array}{l}30 \mathrm{~N} / 108 \mathrm{~W} / \mathrm{Sec} 5 \\
\text { Sublette Cty, } \\
\text { Wyoming }\end{array}$ & $\begin{array}{l}\text { Pinedale } \\
\text { Unit } \\
\text { No. } 5\end{array}$ & $10,950-11,180$ & $10-20-75$ & 518.000 & $\begin{array}{r}183 \mathrm{Emul} \\
8 \mathrm{Gel} \\
459 \mathrm{Gel}\end{array}$ & - & 150 & - \\
\hline \multirow[t]{8}{*}{$\begin{array}{l}\text { GAS PRODUCING } \\
\text { ENTERPRISES. INC. } \\
\text { Uinta, Wasatch } \\
\text { and Mesaverde }\end{array}$} & $\begin{array}{l}\text { 10S/22E/Sec } 10 \\
\text { Uintah Cty. } \\
\text { Utah }\end{array}$ & $\begin{array}{l}\text { Natural } \\
\text { Buttes } \\
\text { No. } 18\end{array}$ & $6,490-8,952$ & $09-22-76$ & $1,480,000$ & $745 \mathrm{Gel}$ & - & 1.400 & 一 \\
\hline & $\begin{array}{l}\text { 10S/21E/Sec } 21 \\
\text { Uintah Cty, } \\
\text { Utah }\end{array}$ & $\begin{array}{l}\text { Natural } \\
\text { Buttes } \\
\text { No. } 19\end{array}$ & $\begin{array}{l}8,909-9,664 \\
7,224-8,676\end{array}$ & $\begin{array}{l}09-21-76 \\
09-28-76\end{array}$ & $\begin{array}{l}424,000 \\
784,000\end{array}$ & $\begin{array}{l}280 \text { Gel } \\
364 \text { Gel }\end{array}$ & - & 166 & 一 \\
\hline & $\begin{array}{l}9 \mathrm{~S} / 21 \mathrm{E} / \mathrm{Sec} 22 \\
\text { Uintah Cty, } \\
\text { Utah }\end{array}$ & $\begin{array}{l}\text { Natural } \\
\text { Buttes } \\
\text { No. } 14\end{array}$ & $6,646-8,004$ & $03-15-77$ & $1,093,000$ & 544 Gel & 38 & 800 & 21.0 \\
\hline & $\begin{array}{l}9 \mathrm{~S} / 21 \mathrm{E} / \mathrm{Sec} 28 \\
\text { Uintah Cty. } \\
\text { Utah }\end{array}$ & $\begin{array}{l}\text { Natural } \\
\text { Buttes } \\
\text { No. } 20\end{array}$ & $8,498-9,476$ & $06-22-77$ & 826.000 & 322 Gel & 75 & 1,200 & 16.0 \\
\hline & $\begin{array}{l}10 S / 22 E / \sec 18 \\
\text { Uintah Cty. } \\
\text { Utah }\end{array}$ & $\begin{array}{l}\text { Natural } \\
\text { Buttes } \\
\text { No. } 22\end{array}$ & $6,838-8,550$ & $11-21-77$ & 1.151 .000 & $499 \mathrm{Gel}$ & - & 700 & - \\
\hline & $\begin{array}{l}9 \mathrm{~S} / 22 \mathrm{E} / \mathrm{Sec} 19 \\
\text { Uintah Cty. } \\
\text { Utah }\end{array}$ & $\begin{array}{l}\text { Natural } \\
\text { Buttes } \\
\text { No. } 9\end{array}$ & $5.661 \cdot 8.934$ & $03-27-78$ & 554,000 & $349 \mathrm{Gel}$ & 140 & 540 & 3.9 \\
\hline & $\begin{array}{l}\text { 10S/21E/Sec } 29 \\
\text { Uintah Cty. } \\
\text { Utah }\end{array}$ & $\begin{array}{l}\text { CIGE } \\
\text { No. } 2\end{array}$ & $\begin{array}{l}9,237-9,653 \\
7,251-8,774\end{array}$ & $\begin{array}{l}06-22-78 \\
08-08-78\end{array}$ & $\begin{array}{r}170,500 \\
1,965,000\end{array}$ & $\begin{array}{l}203 \mathrm{Gel} \\
722 \mathrm{Gel}\end{array}$ & $\square$ & $\begin{array}{l}\text { Water } \\
\text { Water }\end{array}$ & 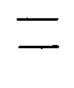 \\
\hline & $\begin{array}{l}\text { 10S/22E/Sec } 7 \\
\text { Uintah Cty. } \\
\text { Utah }\end{array}$ & $\begin{array}{l}\text { Natural } \\
\text { Buttes } \\
\text { No. } 23\end{array}$ & $5,080-6,294$ & $10-04-78$ & 470,000 & $240 \mathrm{Gel}$ & $\longrightarrow$ & 800 & 一 \\
\hline $\begin{array}{l}\text { MITCHELL ENERGY } \\
\text { Cotton Valley, } \\
\text { Limestone Trend }\end{array}$ & $\begin{array}{l}\text { Limestone Cty, } \\
\text { Texas }\end{array}$ & $\begin{array}{l}\text { Muse-Duke } \\
\text { No. } 1\end{array}$ & $11,235-11,418$ & $11-15-78$ & $2,800,000$ & $891 \mathrm{Gel}$ & 2,000 & 6,600 & 3.3 \\
\hline $\begin{array}{l}\text { MOBIL } \\
\text { Piceance. } \\
\text { Mesaverde }\end{array}$ & $\begin{array}{l}2 S / 97 \mathrm{~W} / \mathrm{Sec} 13 \\
\text { Rio Blanco Cty. } \\
\text { Colorado }\end{array}$ & F31-13G & $\begin{array}{c}10,549-10,680 \\
9,392-9,538 \\
8,765-8,972 \\
8,163-8,650 \\
7,704-7,794 \\
7,324-7,476\end{array}$ & $\begin{array}{l}06-22-77 \\
08-24-77 \\
05-10-78 \\
07-06-78 \\
09-07-78 \\
11-15-78\end{array}$ & $\begin{array}{l}580,000 \\
600,000 \\
388,000 \\
660,000 \\
218,000 \\
700,000\end{array}$ & $\begin{array}{l}316 \mathrm{Gel} \\
260 \mathrm{Gel} \\
150 \mathrm{Gel} \\
288 \mathrm{Gel} \\
120 \mathrm{Gel} \\
365 \mathrm{Gel}\end{array}$ & $\begin{array}{r}300 \\
700 \\
479 \\
\square \\
1,000\end{array}$ & $\begin{array}{r}800 \\
2,600 \\
430 \\
360 \\
180 \\
2,000\end{array}$ & $\begin{array}{l}2.7 \\
3.7 \\
- \\
- \\
2.0\end{array}$ \\
\hline $\begin{array}{l}\text { PACIFIC } \\
\text { TRANSMISSION } \\
\text { Uinta, Mesaverde }\end{array}$ & $\begin{array}{l}\text { 8S/23E/Sec } 25 \\
\text { Uintah Cty, } \\
\text { Utah }\end{array}$ & $\begin{array}{l}\text { Federal } \\
23-25\end{array}$ & \multicolumn{4}{|c|}{ NO FRACTURES PERFORMED } & & & \\
\hline $\begin{array}{l}\text { RIO BLANCO } \\
\text { NATURAL GAS } \\
\text { Piceance, Mesaverde }\end{array}$ & $\begin{array}{l}4 \mathrm{~S} / 98 \mathrm{~W} / \mathrm{Sec} 4 \\
\mathrm{Rio} \text { Blanco Cty. } \\
\text { Colorado }\end{array}$ & $\begin{array}{l}\text { Federal } \\
498-4-1\end{array}$ & $\begin{array}{l}6,150 \cdot 6,312 \\
5,376 \cdot 5,960\end{array}$ & $\begin{array}{c}10-22-76 \\
11-30-77 \\
.\end{array}$ & $\begin{array}{l}766,000 \\
243,000+ \\
22,500 \mathrm{Be}\end{array}$ & $\begin{array}{l}276 \mathrm{Gel} \\
164 \mathrm{Gel} \\
\text { eads }\end{array}$ & $\begin{array}{l}57 \\
80\end{array}$ & $\begin{array}{l}130 \\
350\end{array}$ & $\begin{array}{l}2.3 \\
4.4\end{array}$ \\
\hline $\begin{array}{l}\text { WESTCO } \\
\text { Uinta, Mesaverde }\end{array}$ & $\begin{array}{l}10 S / 19 E / \operatorname{Sec} 34 \\
\text { Uintah Cty. } \\
\text { Utah }\end{array}$ & $\begin{array}{l}\text { Home Fed. } \\
\text { No. } 1\end{array}$ & $\begin{array}{c}10,014-10,202 \\
7,826-9,437\end{array}$ & $\begin{array}{l}12-21-76 \\
10-01-76\end{array}$ & $\begin{array}{l}500.000 \\
600.000\end{array}$ & $\begin{array}{l}248 \mathrm{Gel} \\
412 \mathrm{Gel}\end{array}$ & $\begin{array}{l}33 \\
40\end{array}$ & $\begin{array}{c}155 \\
\text { Water }\end{array}$ & 4.7 \\
\hline
\end{tabular}




\section{FRACTURING EXPERIMENT}

\section{CER Corporation}

Las Vegas, Nevada

Interagency Agreement Date:

Anticipated Completion Date:

Project Cost (estimated):

Principal Investigator:

Technical Advisor for DOE:
June 19, 1974

July 1, 1979 (Closing)

DOE . . . . . . . . . . . \$ \$1,975,000

Industry $\ldots \ldots \ldots \ldots \ldots \ldots \ldots \ldots, 1,630,000$

Total . . . . . . . . . . . $\overline{\$ 3,605,000}$

G. R. Luetkehans

C. H. Atkinson

\section{OBJECTIVE}

This stimulation experiment is being conducted in low-permeability, massive gasbearing sandstone reservoirs in the Piceance Basin in western Colorado, to test advanced hydraulic fracturing technology where it has not been possible to obtain commercial production rates. This test is located about 1 mile from the 1973 Rio Blanco nuclear stimulation site to permit comparison of nuclear and hydraulic fracturing techniques in this area.

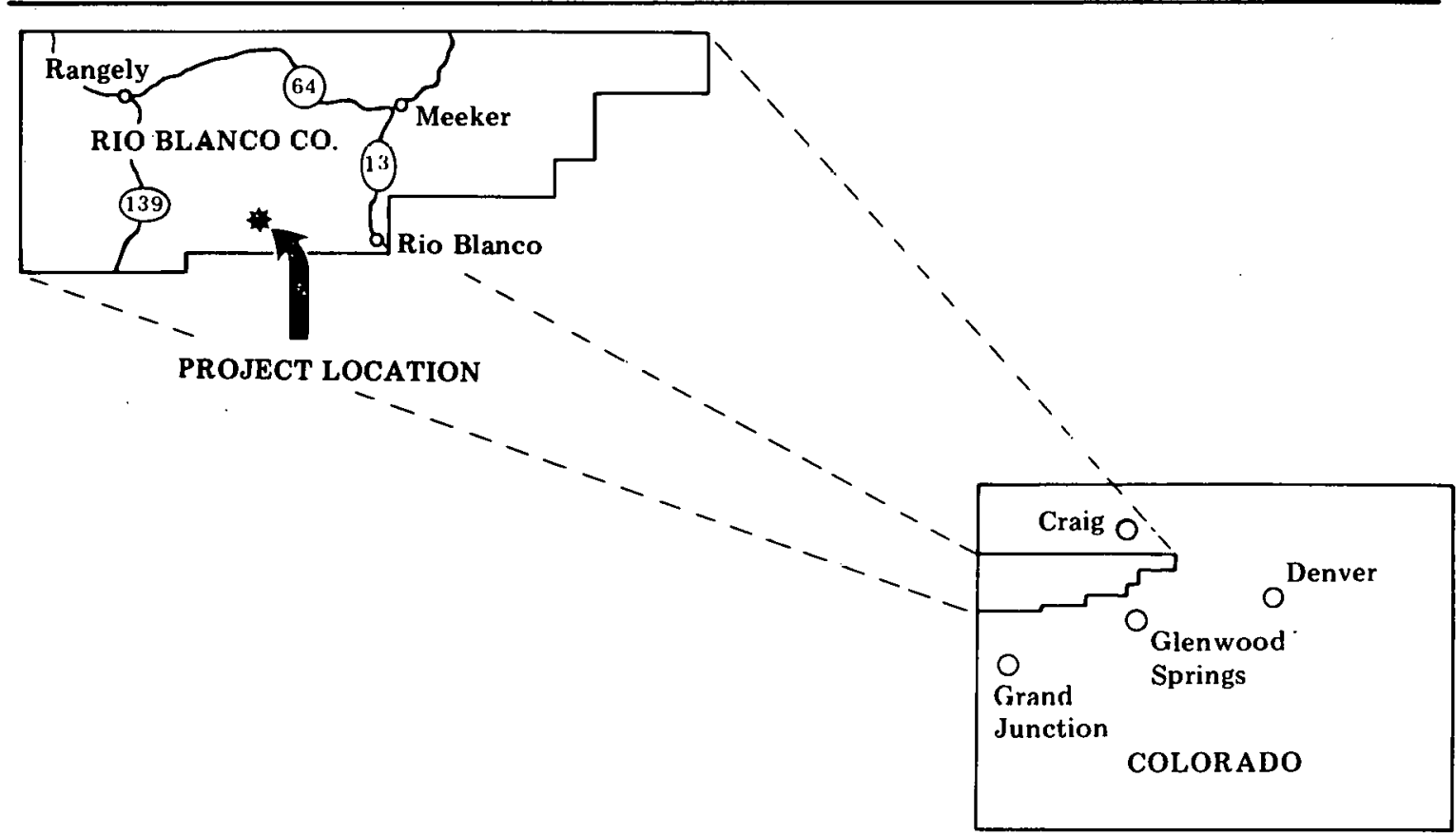




\subsection{CER CORPORATION}

DOE Contract No. DE-AC08-76RA00623 was awarded to CER Corporation in March, 1974. The original contract provided for the drilling of a new well and two MHF treatments. Contract modifications added two additional MHF treatments and extended the termis of the contract.

Field activities on the RB MHF-3 well have been suspended. CER Corporation is transferring the MHF well to an operator who will attempt to complete the well, commingle the previously fractured zones, test the well and provide the data to the industrial participants and DOE.

The transfer is still pending. 
Colorado Interstate Gas Company

Colorado Springs, Colorado

Status: Active

Contract Date:

Anticipated Completion Date:

September 1, 1977

March 1, 1981

Total Project Cost (estimated):

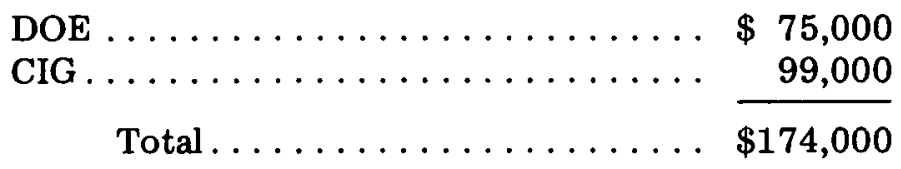

Principal Investigator:

David Wilson

Technical Project Officer for DOE:

C. H. Atkinson

\section{OBJECTIVE}

Cyclic injection of dry natural gas is the method to be used to increase production of tight gas sands.

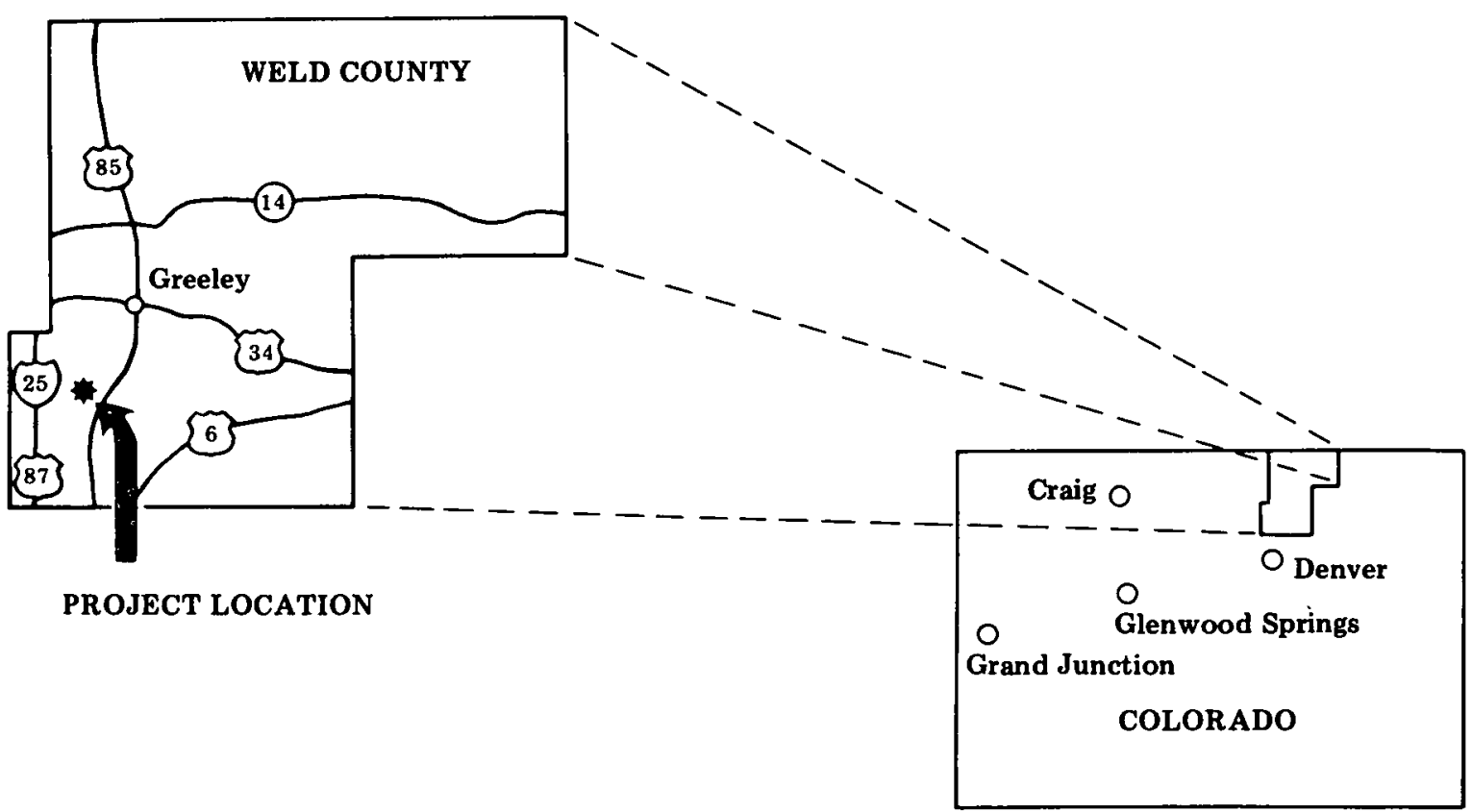




\subsection{COLORADO INTERSTATE GAS COMPANY}

Cyclic injection of dehydrated gas and production continued at the Miller No. 1 and Sprague No. 1 wells. The Texstream diaphragm regulator has been installed on the suction side of the compressor. This should eliminate shutdowns due to low pressure.

Figure 5-1 illustrates the injection and production volumes and associated pressures of the wells. 


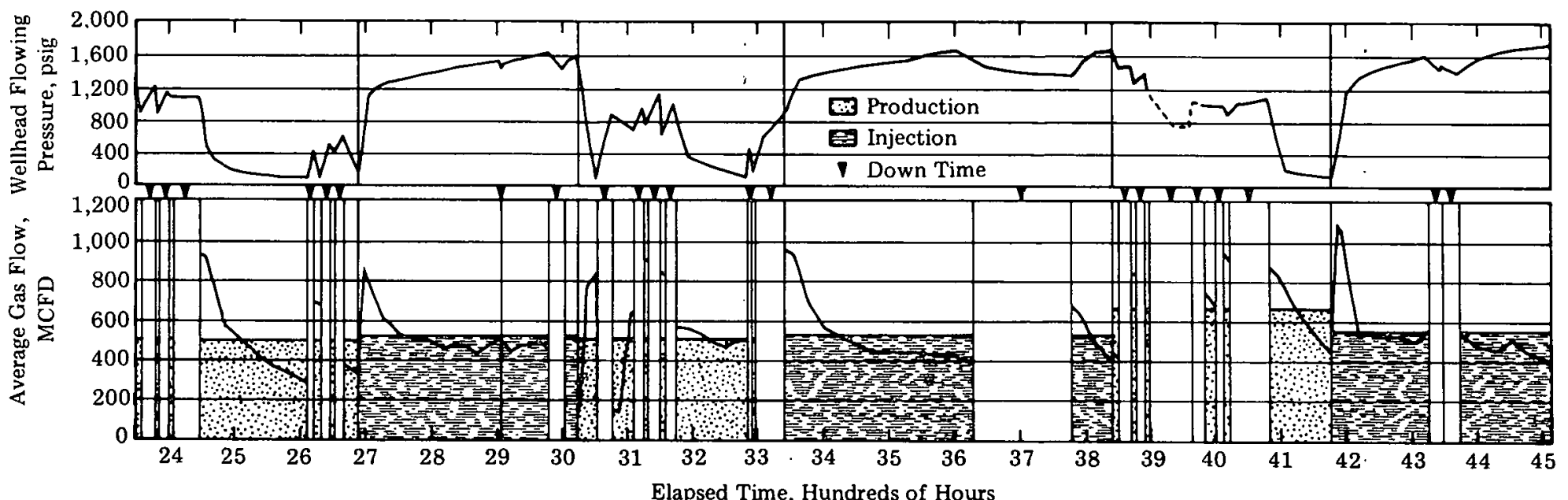

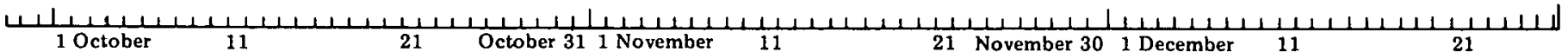

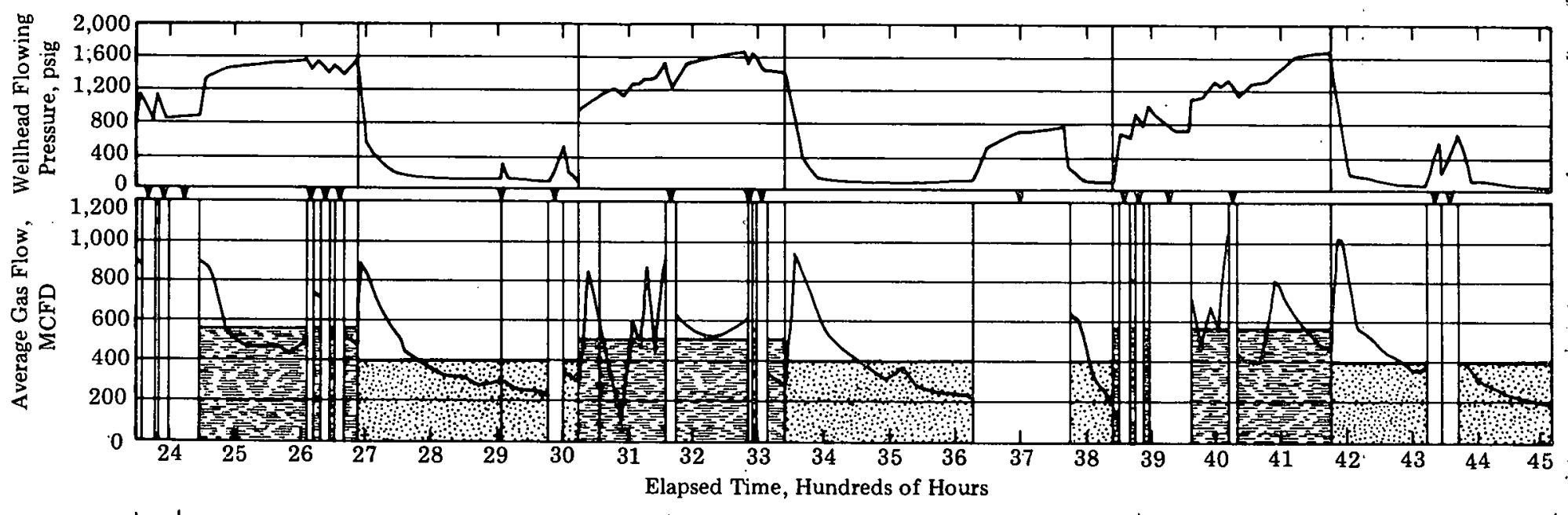

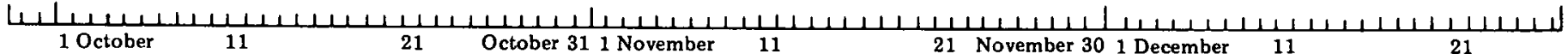

Figure 5-1 Production and Injection Volumes and Associated Pressure of CIG Miller No. 1 and Sprague No. 1 Wells 
CER Corporation

Status: Operational

Las Vegas, Nevada

Principal Investigator:

R. L. Mann

Technical Advisor for DOE:

C. H. Atkinson

\section{OBJECTIVE}

The DOE Well Test Facility, consisting of two vehicles, will provide a deep well instrumentation and investigation system to monitor and evaluate the productive potential of all types of wells.

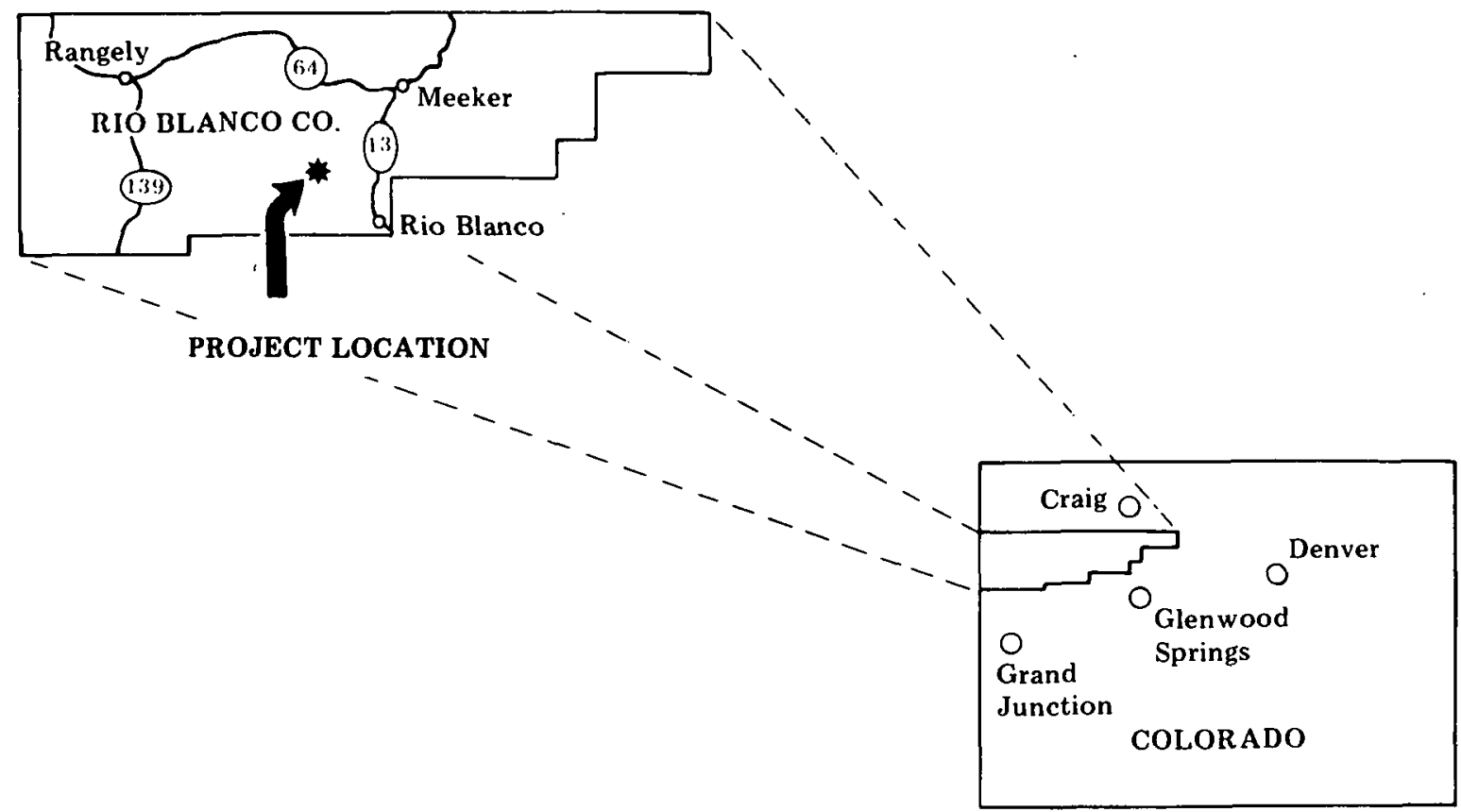




\subsection{DOE WELL TEST FACIITY}

The well test facility generators were taken to Denver for overhaul and general clean-up in preparation for the facility being transferred to CIG Miller No. 1 and Sprague No. 1 wells. Testing will proceed during the following months. 


\section{NATURAL BUTTES UNIT, UINTAH COUNTY，DE-AC08-76 ET 12060 UTAH MASSIVE HYDRAULIC FRACTURING DEMONSTRATION}

Gas Producing Enterprises, Inc.

Status: Active

Subsidiary of Coastal States Gas Co.

Houston, Texas

Contract Date:

July 1,1976

Anticipated Completion:

March 31, 1980

Total Project Cost (estimated):

DOE . . . . . . . . . . . . . . \$2,827,000

Industry (prior costs) $\ldots \ldots \ldots \ldots \ldots, 1,881,000$

Industry (new costs) . . . . . . . 3,051,000

Total .............. $\overline{\$ 7,759,000}$

Principal Investigator:

W. E. Spencer

Technical Project Officer for DOE:

C. H. Atkinson

\section{OBJECTIVE}

To evaluate the effectiveness of massive hydraulic fracturing for stimulating natural gas production from thick, deep sandstone reservoirs having low-permeability.

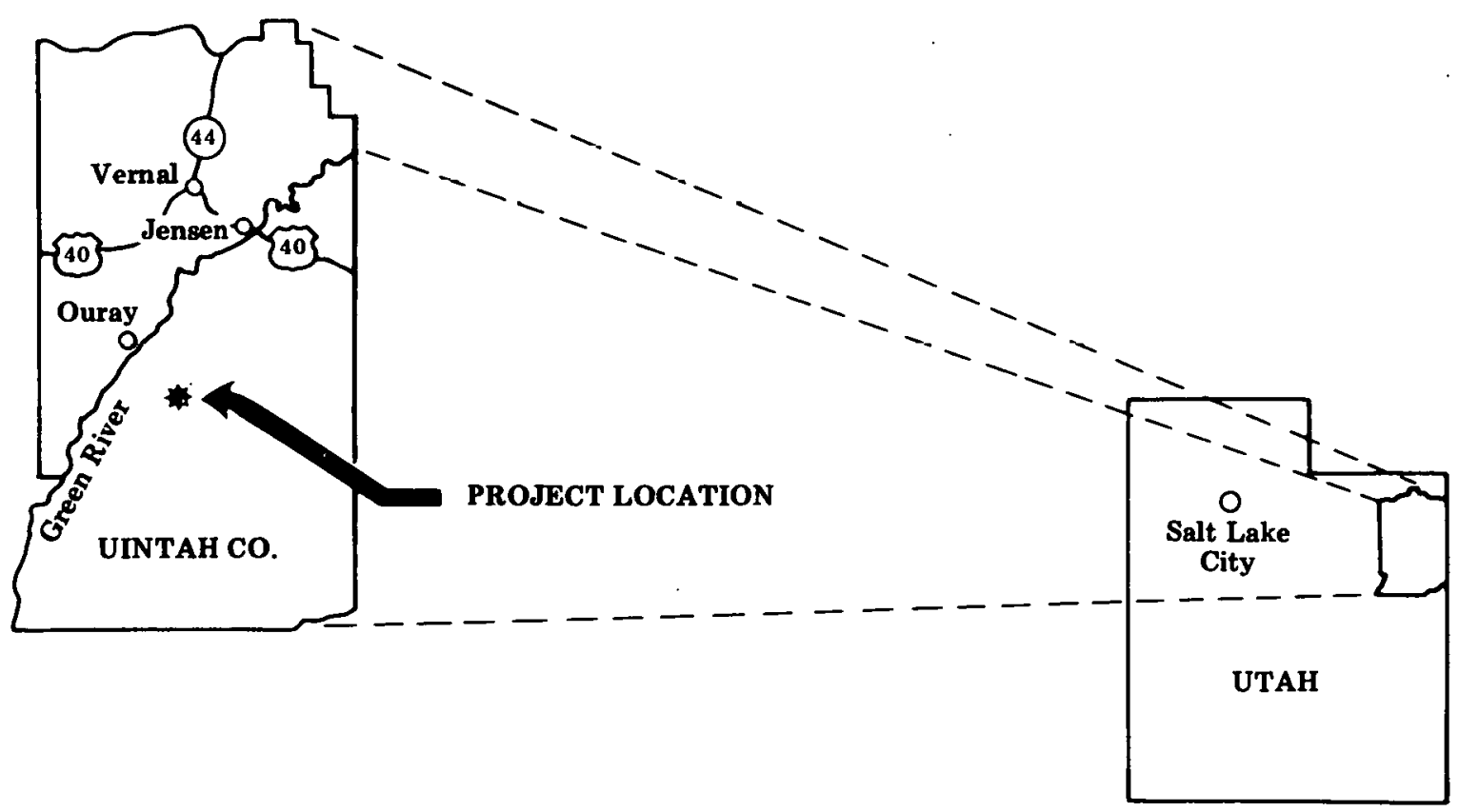




\subsection{GAS PRODUCING ENTERPRISES}

During December, GPE Natural Buttes Unit Nos. 9, 14, 18 and 20 flowed to sales. Natural Buttes Unit No. 19 was shut in due to overproduction. NBU No. 22 was making too much water, so production logs will be run and a decision will be made in February as to the future of the well. Figures 5-2 through 5-7 show production figures of these wells.

CIGE No. 2, fractured August 8, 1978, was subsequently worked-over to clean out sand that had plugged the wellbore. It could not be produced immediately because of delay in connecting the well to a pipeline. After the connection was made and the well was put on production, it began producing excessive amounts of water. Gas production could not be sustained. A workover will be considered to shut off water production if the waterproducing zone can be located with logging tools. 


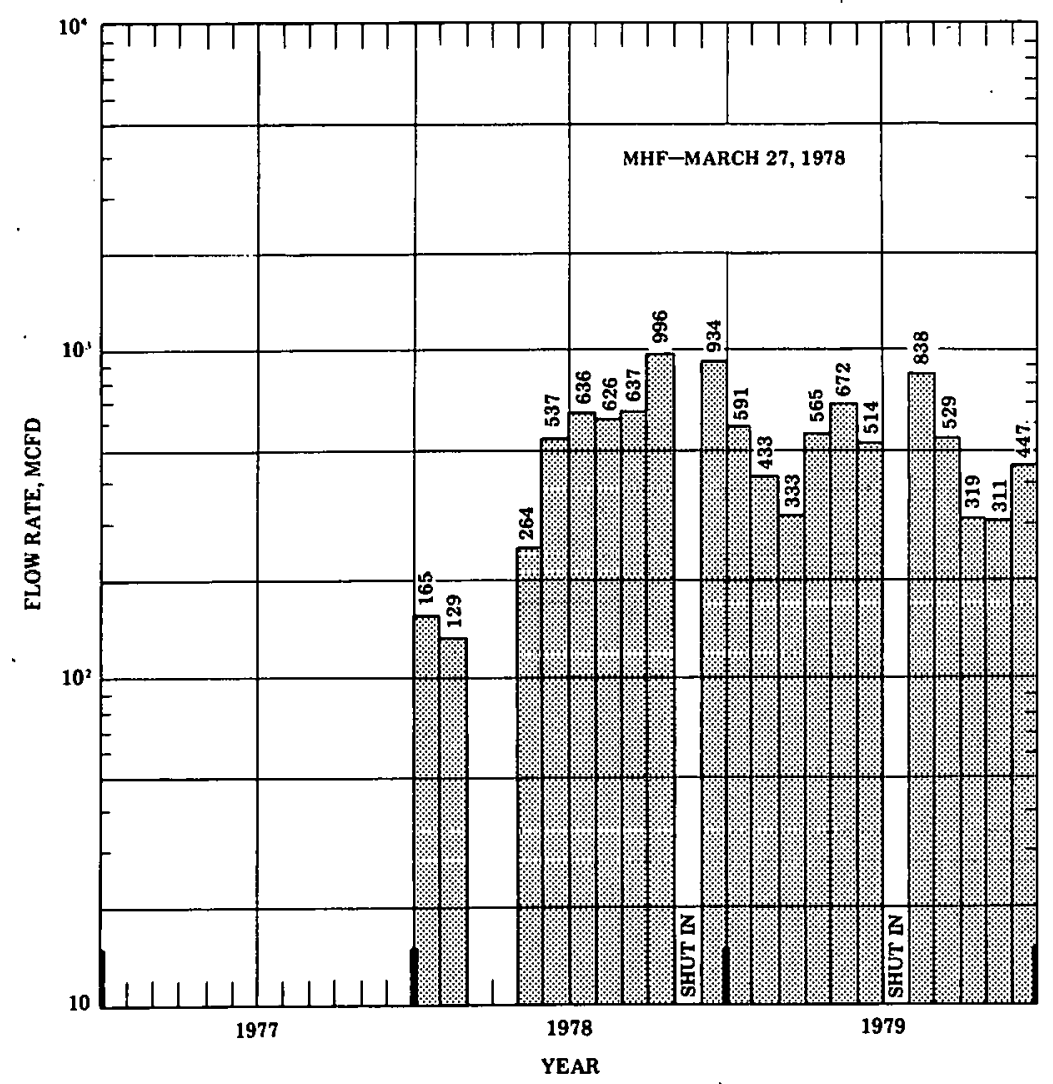

Figure 5-2

Flow Rate Performance of. Natural Buttes No. 9 Well

Figure 5-3

Flow Rate Performance of . Natural Buttes No. 14 Well

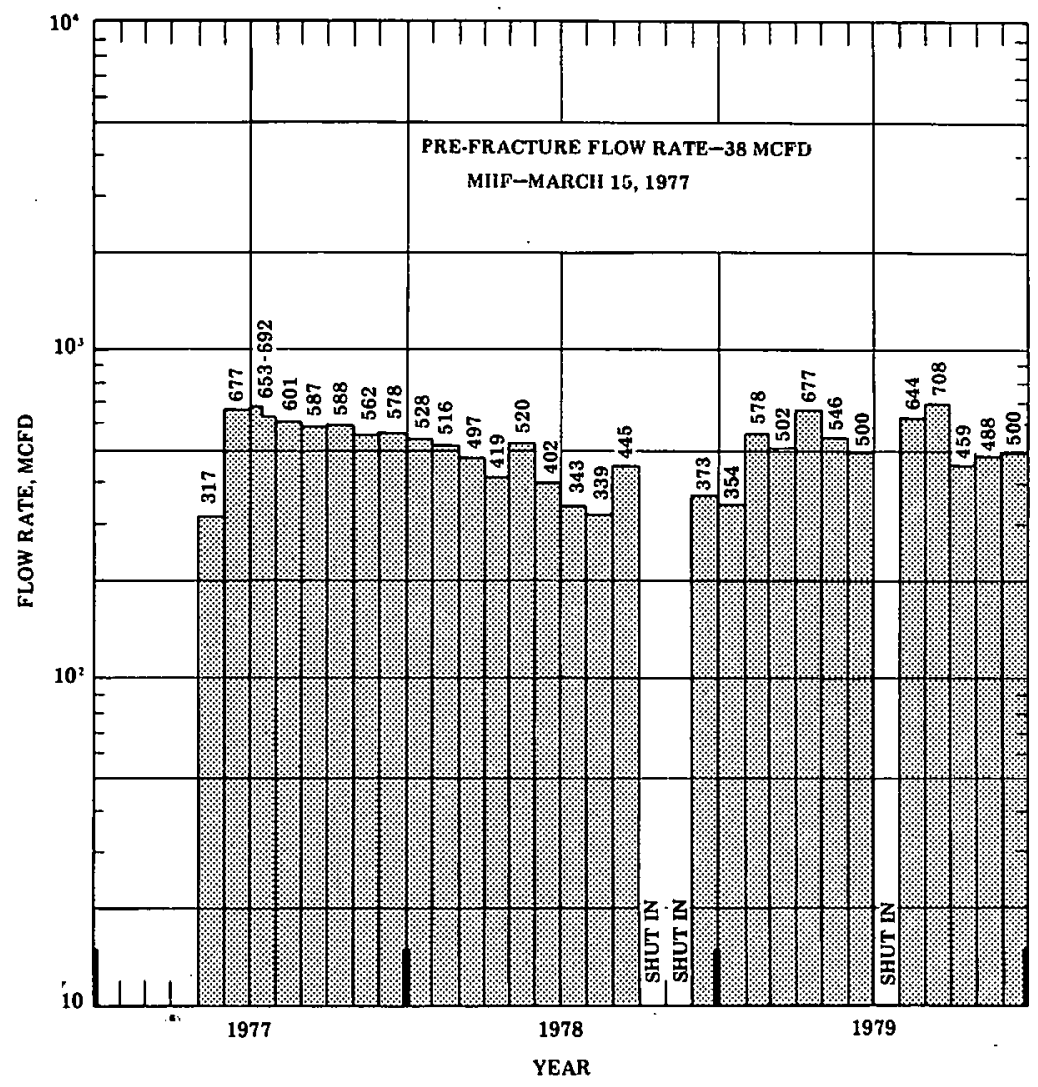


Figure 5-4

Flow Rate

Performance of Natural Buttes

No. 18 Well
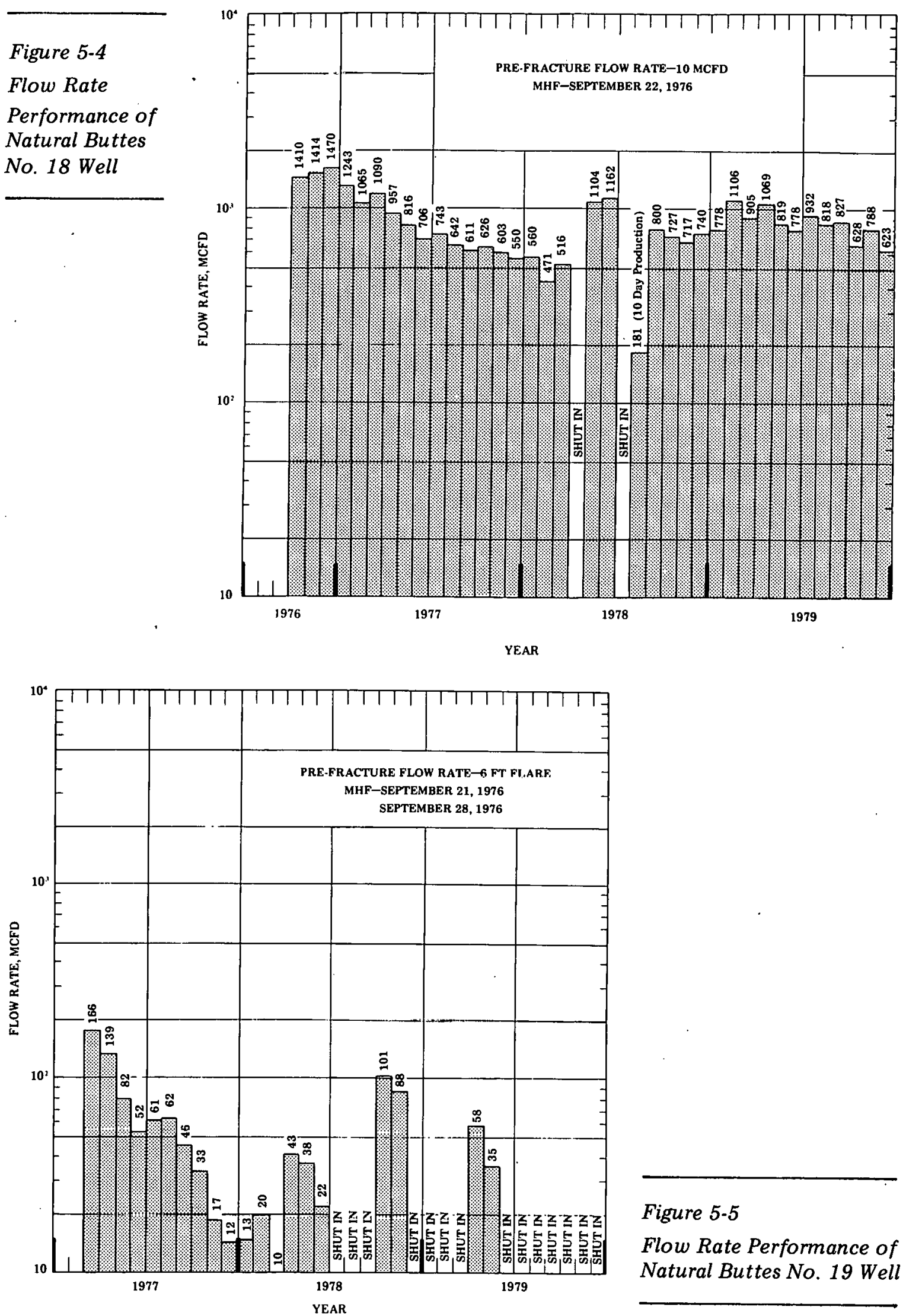

Figure 5-5

Flow Rate Performance of Natural Buttes No. 19 Well 


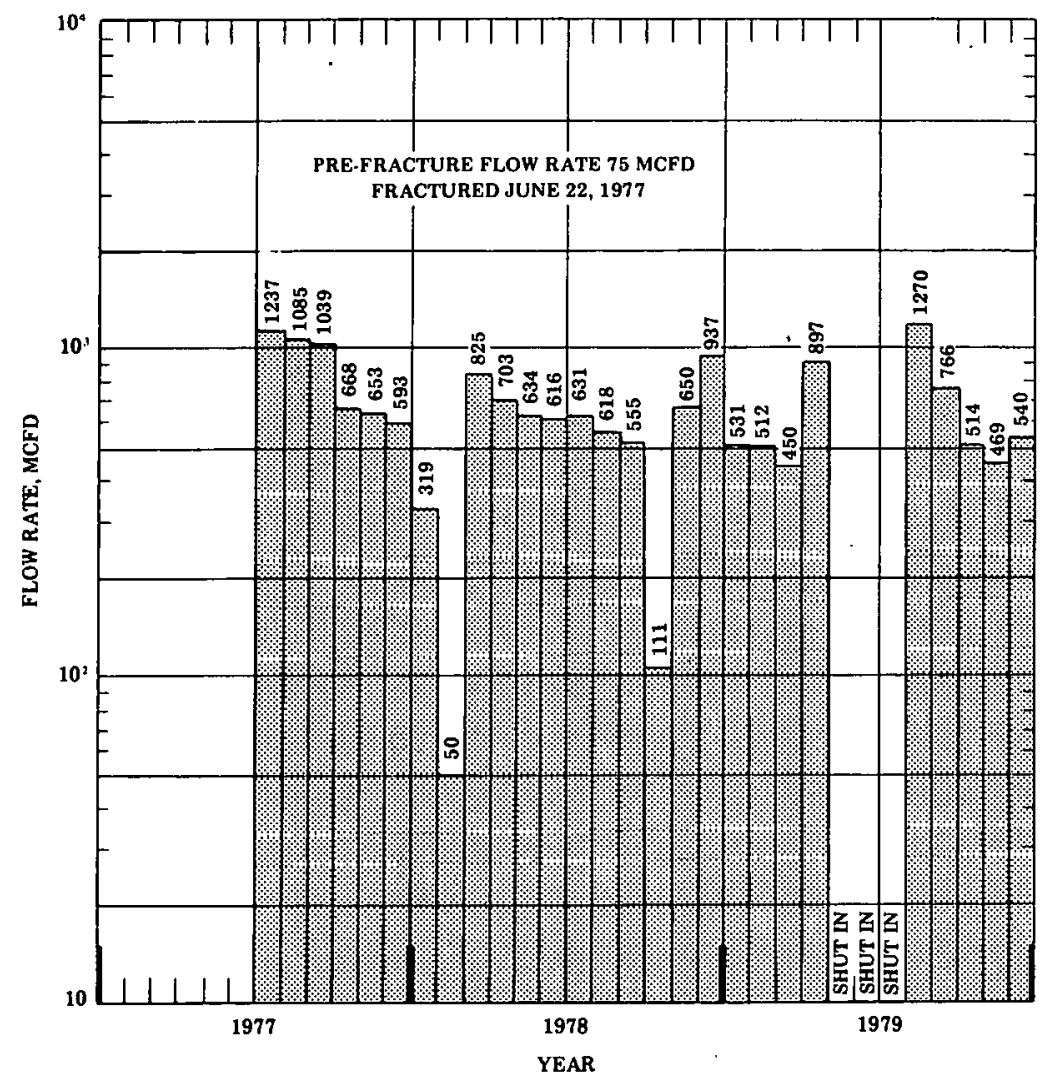

Figure 5-6

Flow Rate Performance of Natural Buttes No. 20 Well

Figure 5-7

Flow Rate Performance of Natural Buttes No. 22 Well.

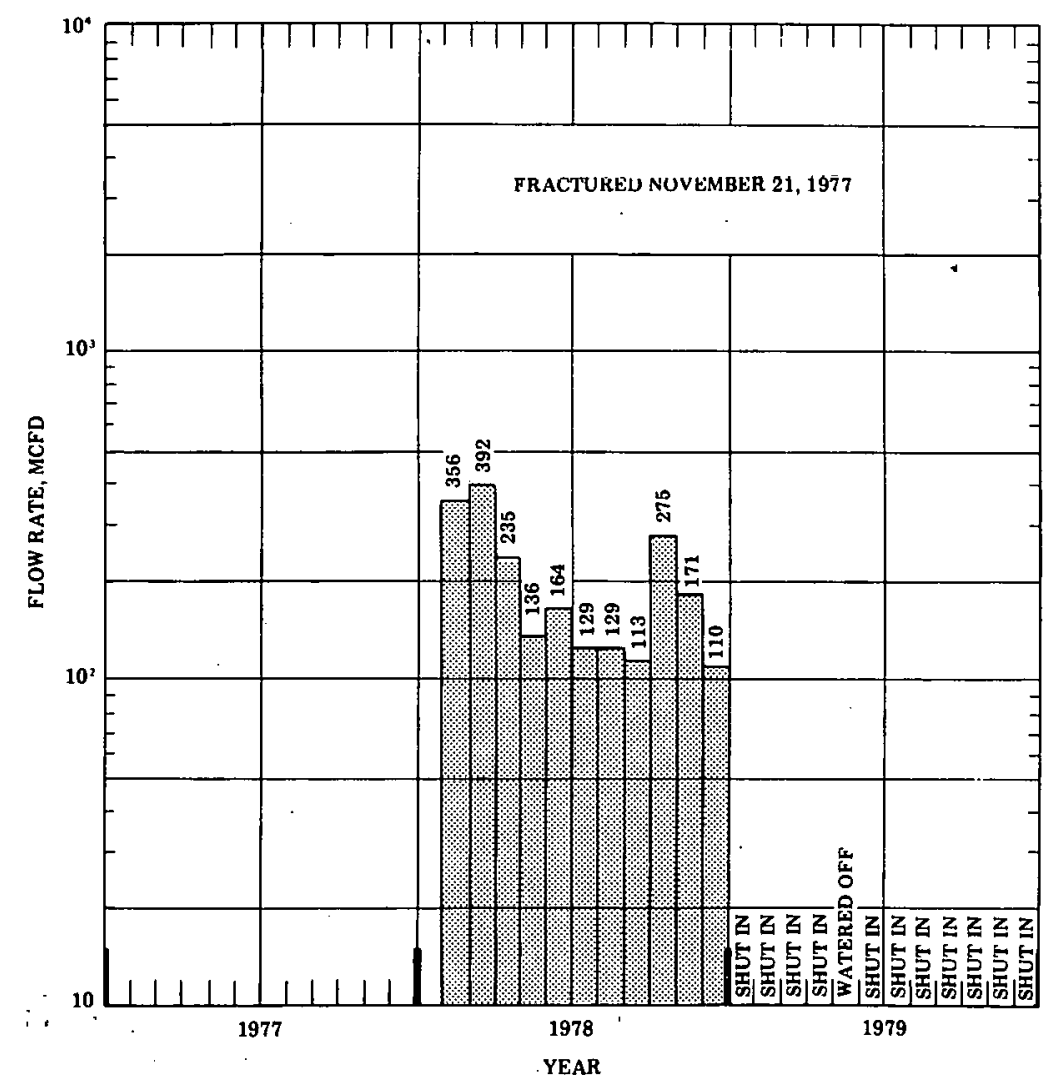


FALLON-NORTH PERSONVILLE FIELD,

DE - AC08 - 78ET12150 TEXAS, MASSIVE HYDRAULIC FRACTURING DEMONSTRATION

Mitchell Energy Corporation

Status: Active

Houston, Texas

Contract Date:

Anticipated Completion:

March 15, 1978

April 30, 1979 (Extension being processed)

Total Project Cost (estimated):

DOE $\ldots \ldots \ldots \ldots \ldots \ldots \ldots \ldots \ldots \$ \ldots 53,771$

Industry $\ldots \ldots \ldots \ldots \ldots \ldots \ldots \ldots \ldots$

Total . . . . . . . . . . . \$1,628,321

Principal Investigator:

F. D. Covey

Technical Project Officer for DOE:

C. H. Atkinson

\section{OBJECTIVE}

To test massive hydraulic fracturing in the Cotton Valley Limestone Formation.

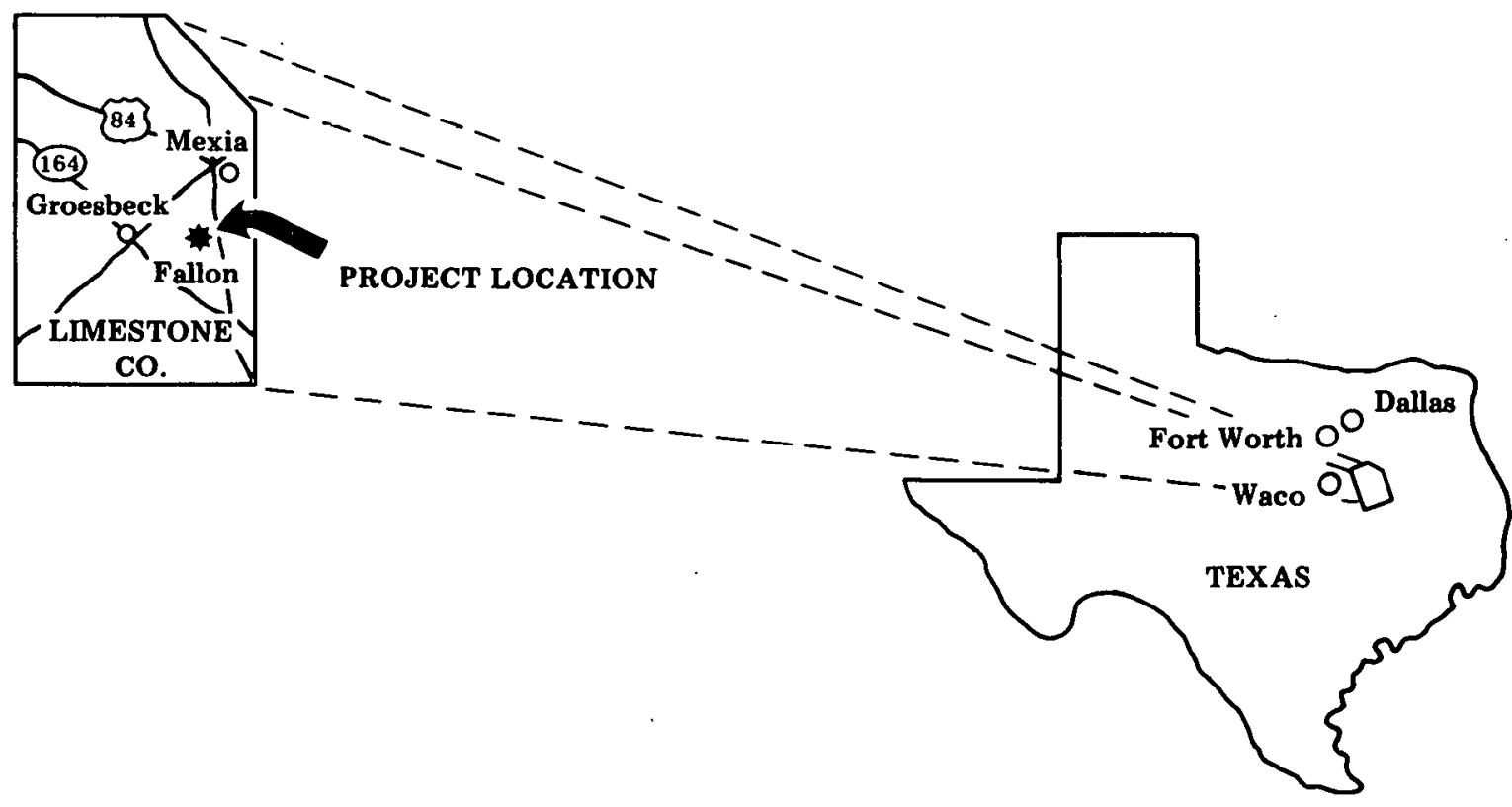




\subsection{MITCHELL ENERGY CORPORATION}

A draft of the final report is expected by mid-March. 
PICEANCE CREEK FIELD, COLORADO,

DE - AC08 - 76ET12062

\section{MASSIVE HYDRAULIC FRACTURING}

\section{DEMONSTRATION}

Mobil Research and Development Corporation

Status: Active

Dallas, Texas

Contract Date:

July 1,1976

Anticipated Completion:

September 30, 1979

Total Project Cost (estimated):

DOE

$\$ 2,510,000$

Contractor (prior costs). . . . . . . . 2,376,485

Contractor (new costs) . . . . . . . 1,590,515

Total . . . . . . . . . . . . \$6,477,000

Principal Investigator:

John L. Fitch

Technical Project Officer for DOE:

C. H. Atkinson

\section{OBJECTIVE}

To evaluate the effectiveness of massive hydraulic fracturing for stimulating natural gas production from thick, deep sandstone reservoirs having extremely low-permeability.

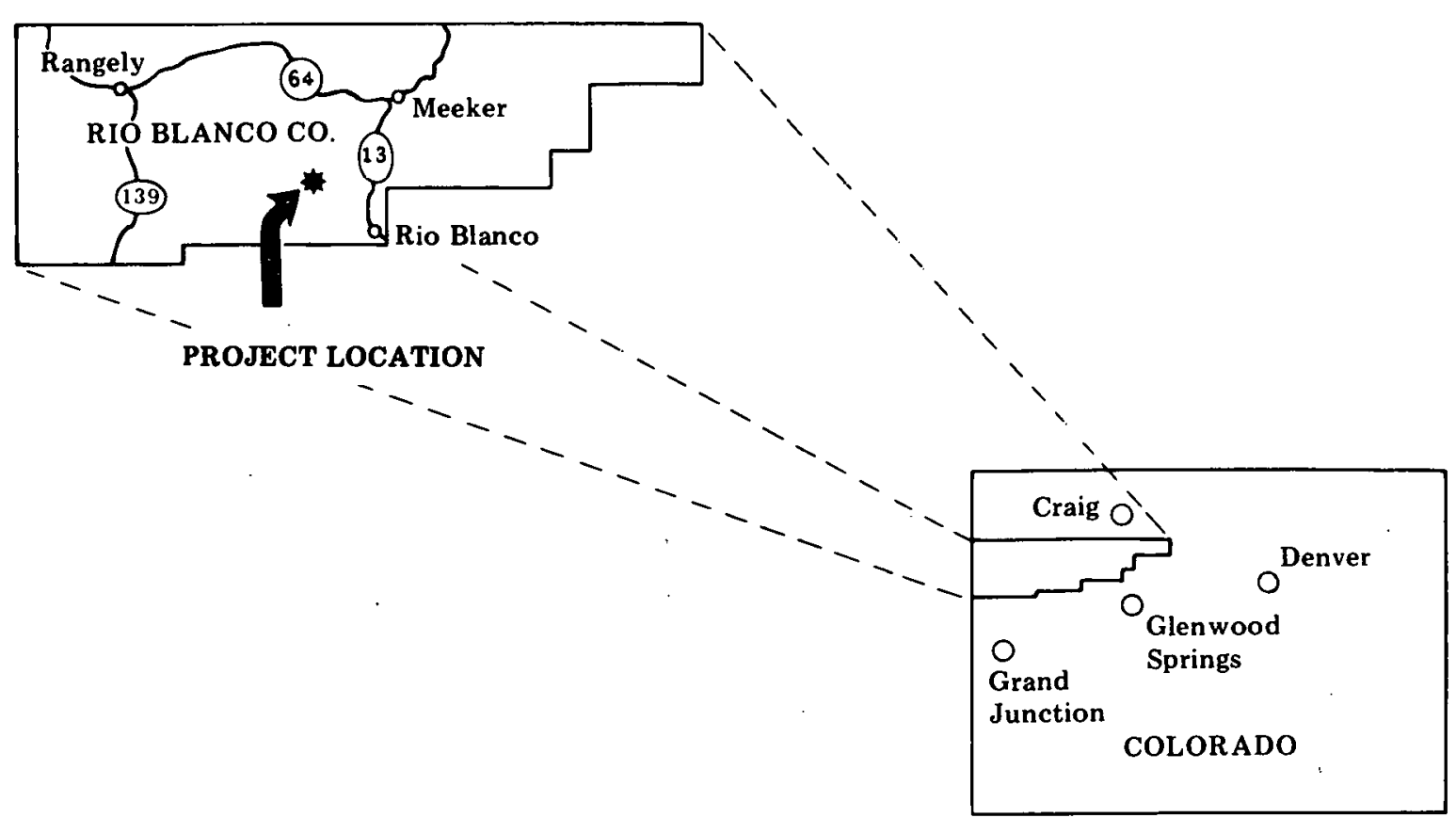


THIS PAGE

\section{WAS INTENTIONALLY LEFT BLANK}




\section{MASSIVE HYDRAULIC FRACTURING} DEMONSTRATION

Rio Blanco Natural Gas Company

Status: Active

Denver, Colorado

Contract Date:

Anticipated Completion:

Total Project Cost (estimated):

Principal Investigator:

Technical Project Officer for DOE:

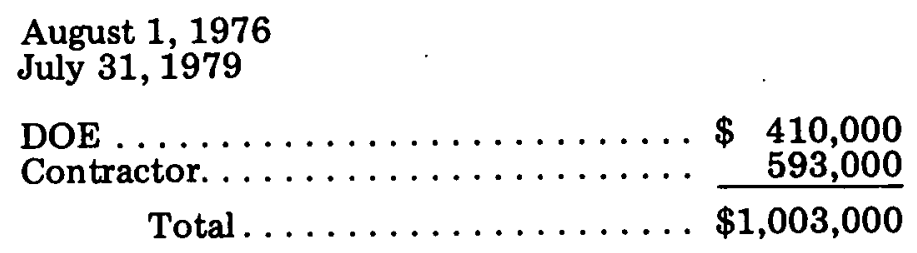

Robert E. Chancellor

C. H. Atkinson

\section{OBJECTIVE}

To evaluate the effectiveness of massive hydraulic fracturing for stimulating natural gas production from thick, deep sandstone reservoirs having extremely low permeability.

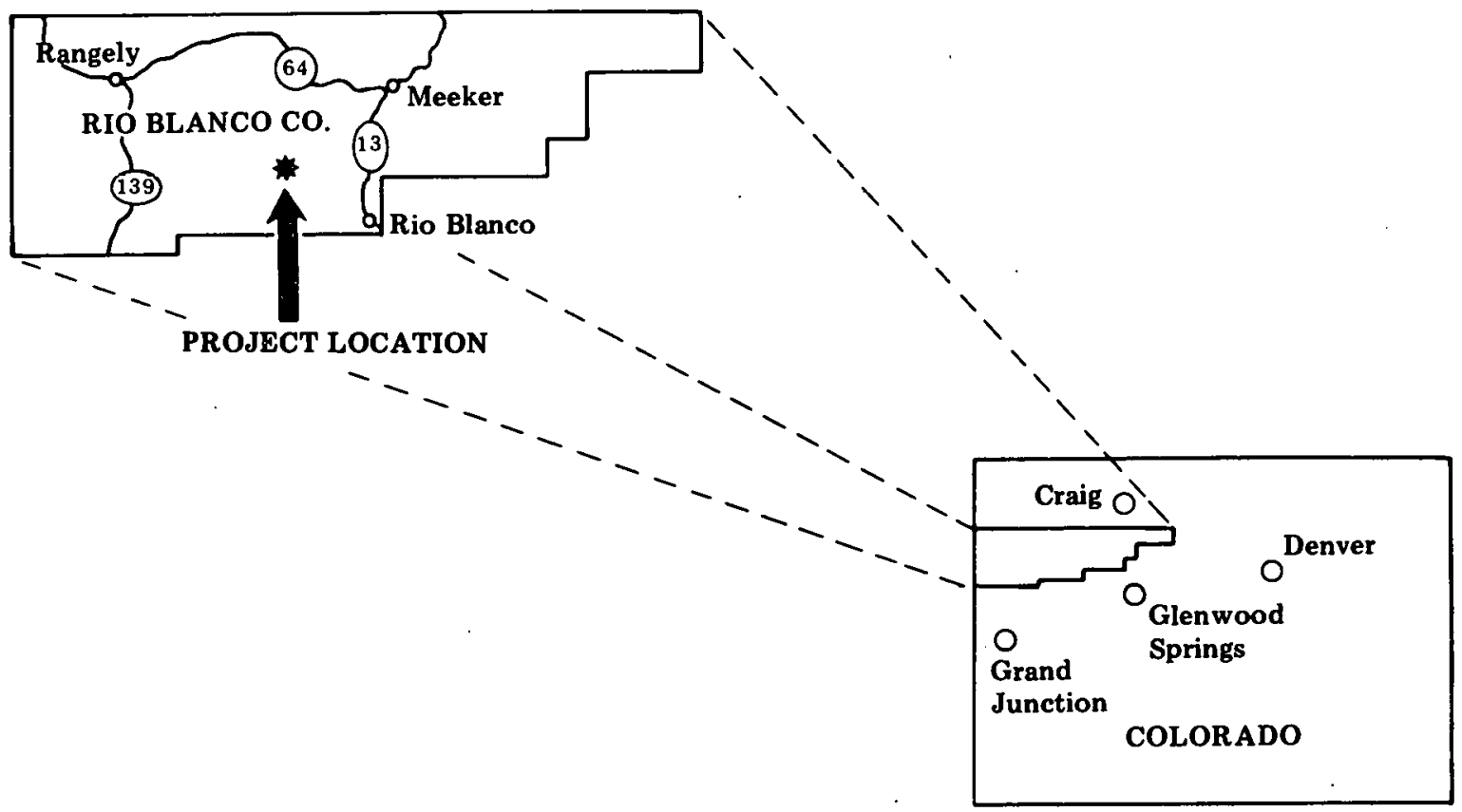




\subsection{RIO BLANCO NATURAL GAS COMPANY}

DOE Contract No. DE-AC08-76ET12148 was signed with Rio Blanco Natural Gas Company in June, 1976. The first MHF treatment was performed on October 22, 1976. A supplemental agreement, effective October 1,1977 , provided for a second MHF treatment which was performed on November 30, 1977.

The final report has been issued and the contract closed. 
NEVADA TEST SITE

NYE COUNTY, NEVADA

MINEBACK TESTING

Sandia Laboratories

Status: Active

Albuquerque, New Mexico

Principal Investigator:

D. A. Northrop

\section{OBJECTIVE}

To develop an understanding of the fracturing process for stimulation and thereby improve the production of natural gas from low-permeability reservoirs. This will be accomplished by conducting controlled fracture experiments which are accessible by mineback for direct observation and evaluation.

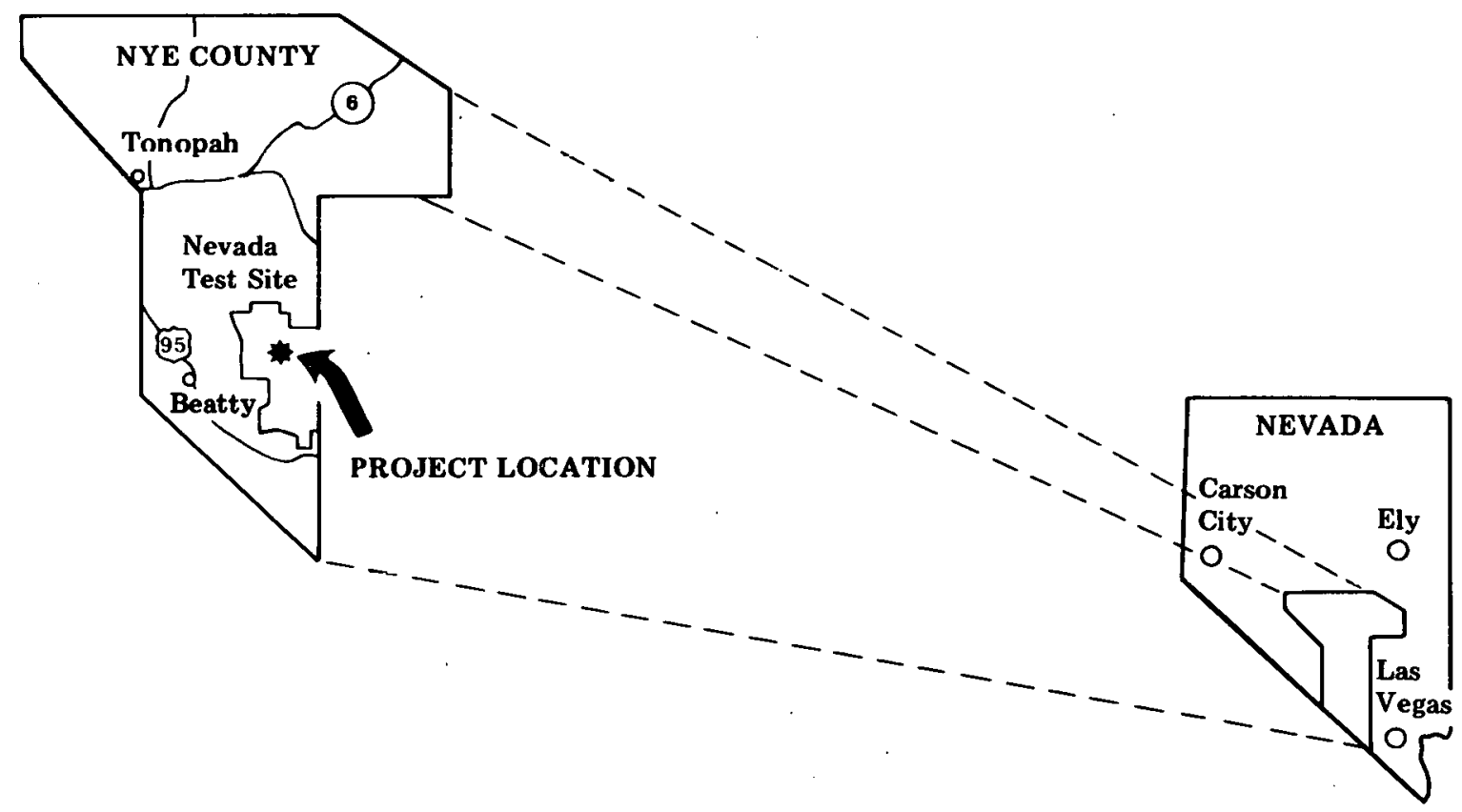




\subsection{SANDIA MINEBACK}

\subsubsection{Hydraulic Fracturing Containment Experiments}

\subsubsection{Hole No. 6 Formation Interface Fracture Experiment}

Twenty-three coreholes have been completed to date, including EV6-28 which was cored in November/December. The location of this hole is shown in Figure 5-8. It is only a few feet below the upper boundary of the welded tuff and an overlying ashfall tuff formation. The next two coreholes will continue to explore this area, particularly to determine if the fractures propagated up into the overlying ashfall tuff.

\subsubsection{Interface Test Series}

The last phase of the interface test series is to perform minifracs in one specific area to determine the actual vertical distribution of stress near the interface. The previous experiments qualitatively provide these data, but it is impossible to factor out the horizontal variations which are included in those numbers. These data will further aid in the interpretation of the results as well as give insight as to what types of stress distributions can be expected in layered media.

\subsubsection{Rock Mechanics}

In order to investigate the origin of the stress variations observed in the interface test series, finite element methods were used to calculate the in situ stress in a linear elastic and isotropic material where the Young's modulus of the medium varies by a factor of five. The results indicate that the horizontal in situ stress in the vicinity of the high modulus material (Figure 5-9) is very sensitive to the relative values of overburden pressure, $\sigma \mathrm{V}$, and the horizontal far field stress, $\sigma_{\mathrm{H}}$. Figure 5-10 illustrates the depth-dependent variation of the horizontal in situ stress for several values of $\sigma \mathrm{H} / \sigma \mathrm{V}$. In the high modulus material, the horizontal in situ stress varies from strongly compressional for $\sigma \mathrm{H} / \sigma \mathrm{V} \sim 1.0$ to tensional when $\sigma \mathrm{H} / \sigma \mathrm{V}$ $\sim 0.1$. Therefore, material property variations in the stratigraphic column may still be important since they determine the in situ stress state which, in turn, controls hydraulic fracture growth.

\subsubsection{Fluid Mechanics}

No further development work on the hydraulic fracturing model was performed in this reporting period. Efforts to develop flow or pressure tests for determining the conductivity of a propped hydraulic fracture are continuing. These tests will be used in conjunction with proppant transport mineback experiments being planned for 1980 . 

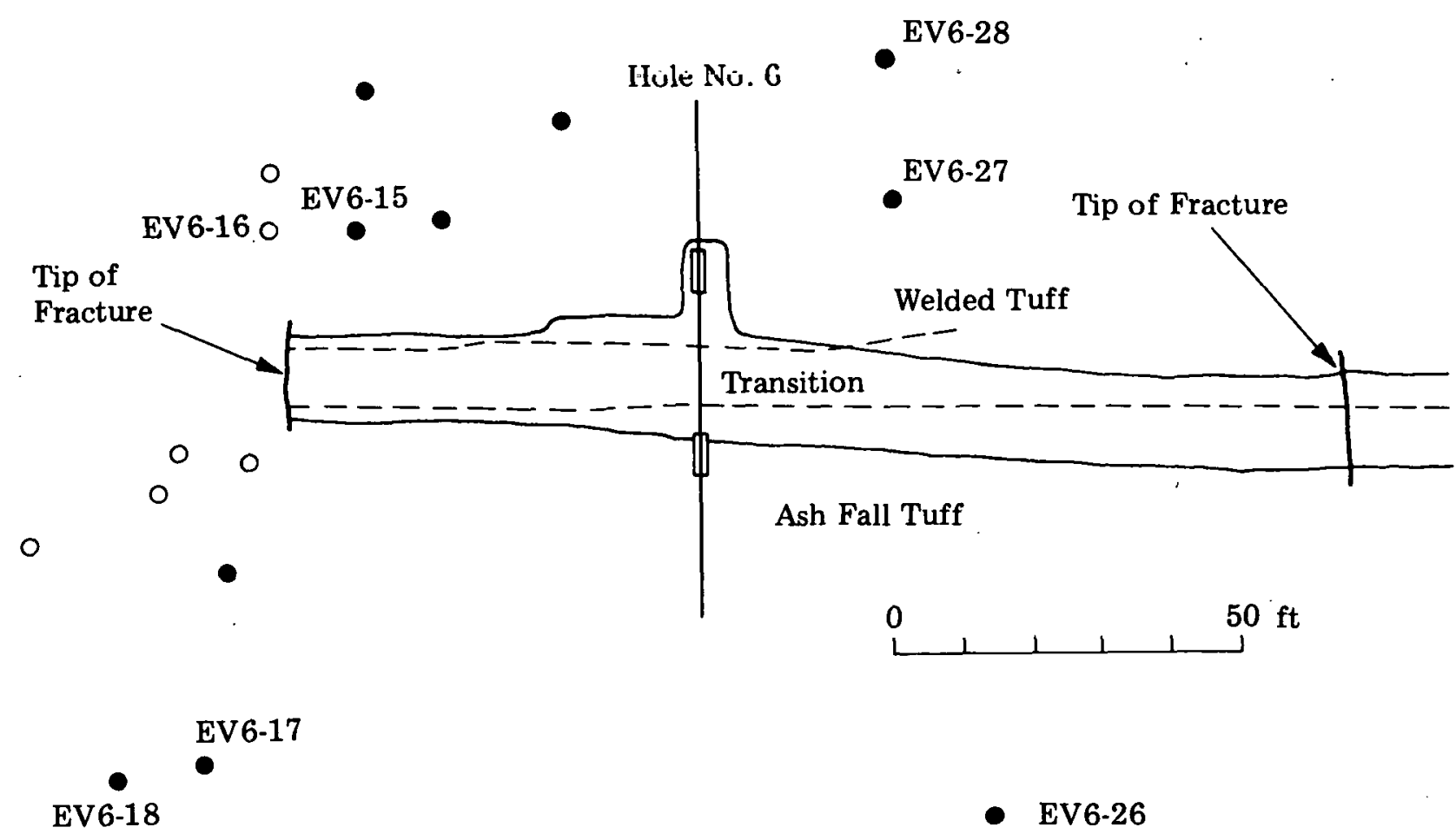

Located Grout

o No Grout

EV6-22

O EV6-25

EV6-23

EV6-24

Figure 5-8 Results of Exploratory Coring of Hole No. 6 


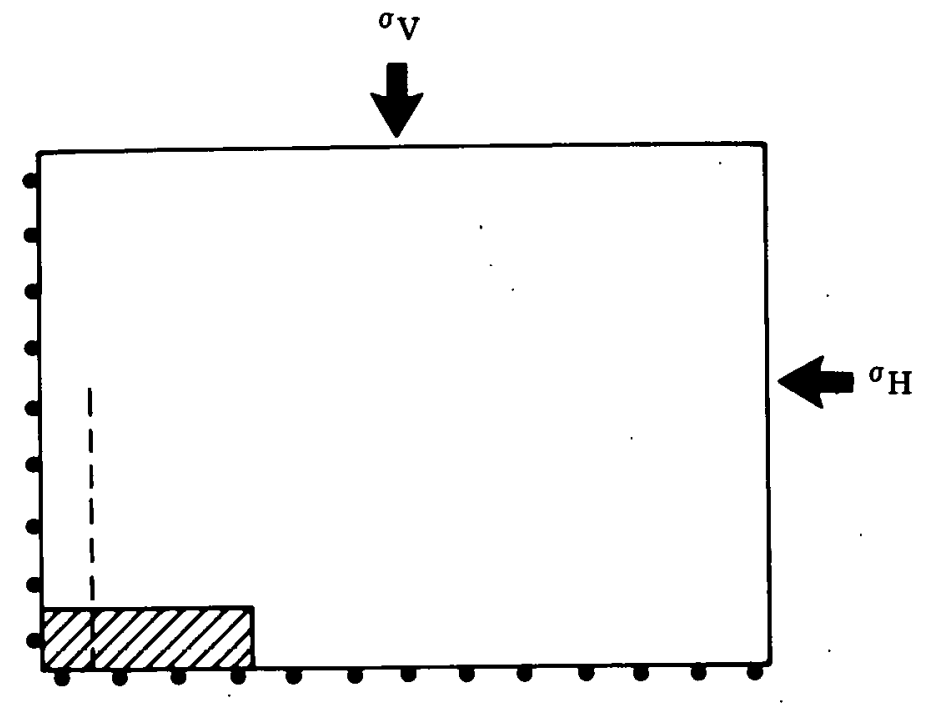

Figure 5-9

Geometry for the finite element stress calculations. The Young's modulus in the shaded area is five times that of the surrounding region. Poisson's ratio is 0.25 times throughout. Stresses shown in Figure 5-10 were determined along the vertical dashed line.

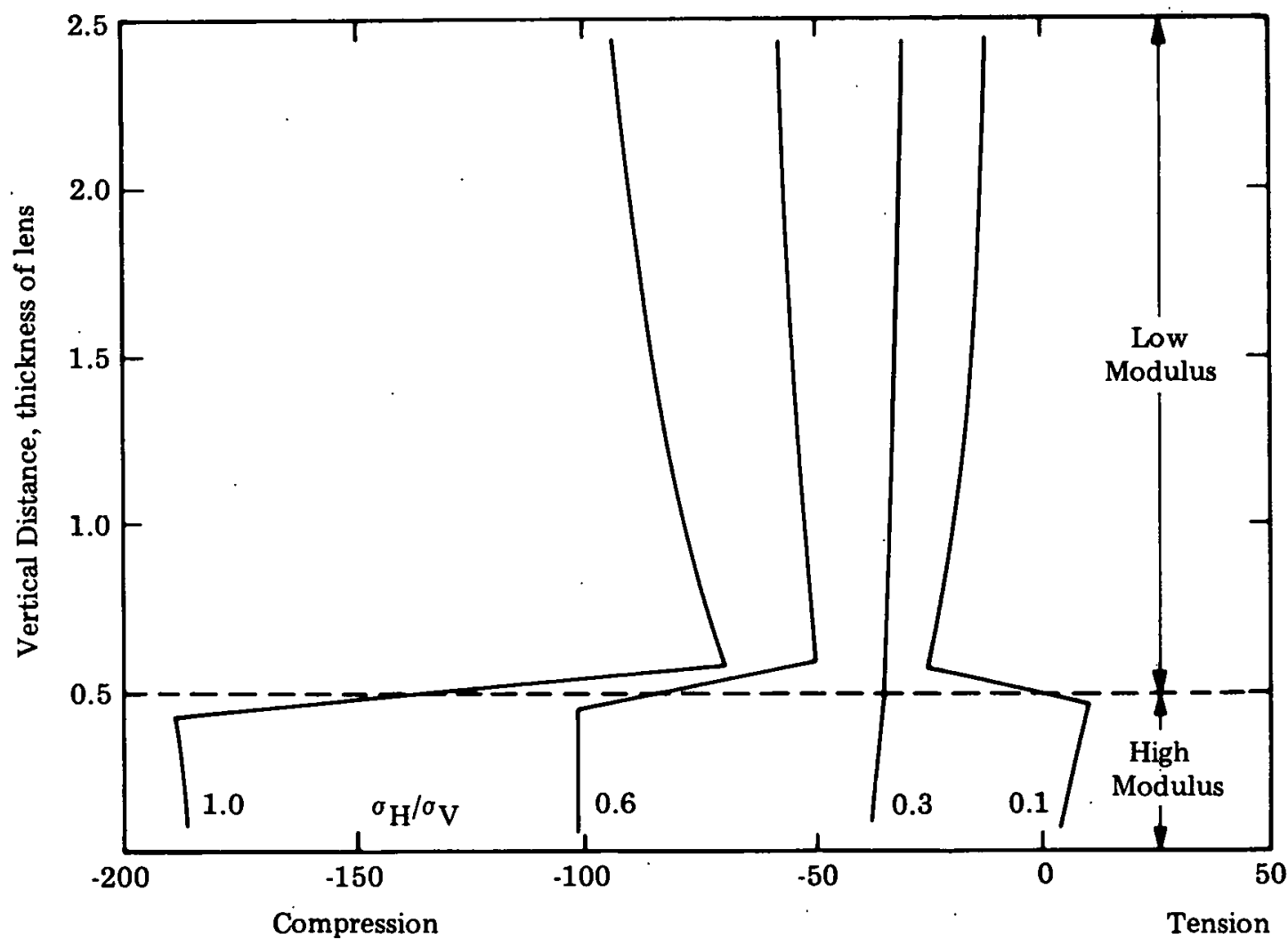

Horizontal In Situ Stress, percent of ${ }^{\sigma} \mathrm{V}$

Figure 5-10 Horizontal in situ stress for differing values of $\sigma_{H} / \sigma \mathrm{V}$ 


\subsubsection{Geochemistry and Petrology}

Samples from Mapco RBU No. 11-17F well, Uintah County, Utah, have been received for petrographic study. While thin sections of these rocks are being prepared for characterization of the mineralogy, texture and diagenetic history, preliminary observations have been made using the scanning electron microscope. These observations have shown an abundance of authigenic clay lining and filling the pore spaces. In addition, authigenic quartz is common.

X-ray diffraction analyses of these samples have not yet been completed. However, the preliminary SEM observations of the samples examined so far appear to indicate that the abundance of chlorite decreases with core depth.

Porosity in some of these samples shows both tabular and spherical pores. It will be necessary to use one of the pre-cast techniques involving epoxy or Wood's metal in order to obtain an accurate description of pore geometries.

\subsubsection{Schedule Status}

Figure 5-11 is a milestone chart of the Sandia mineback progress within the WGSP. 


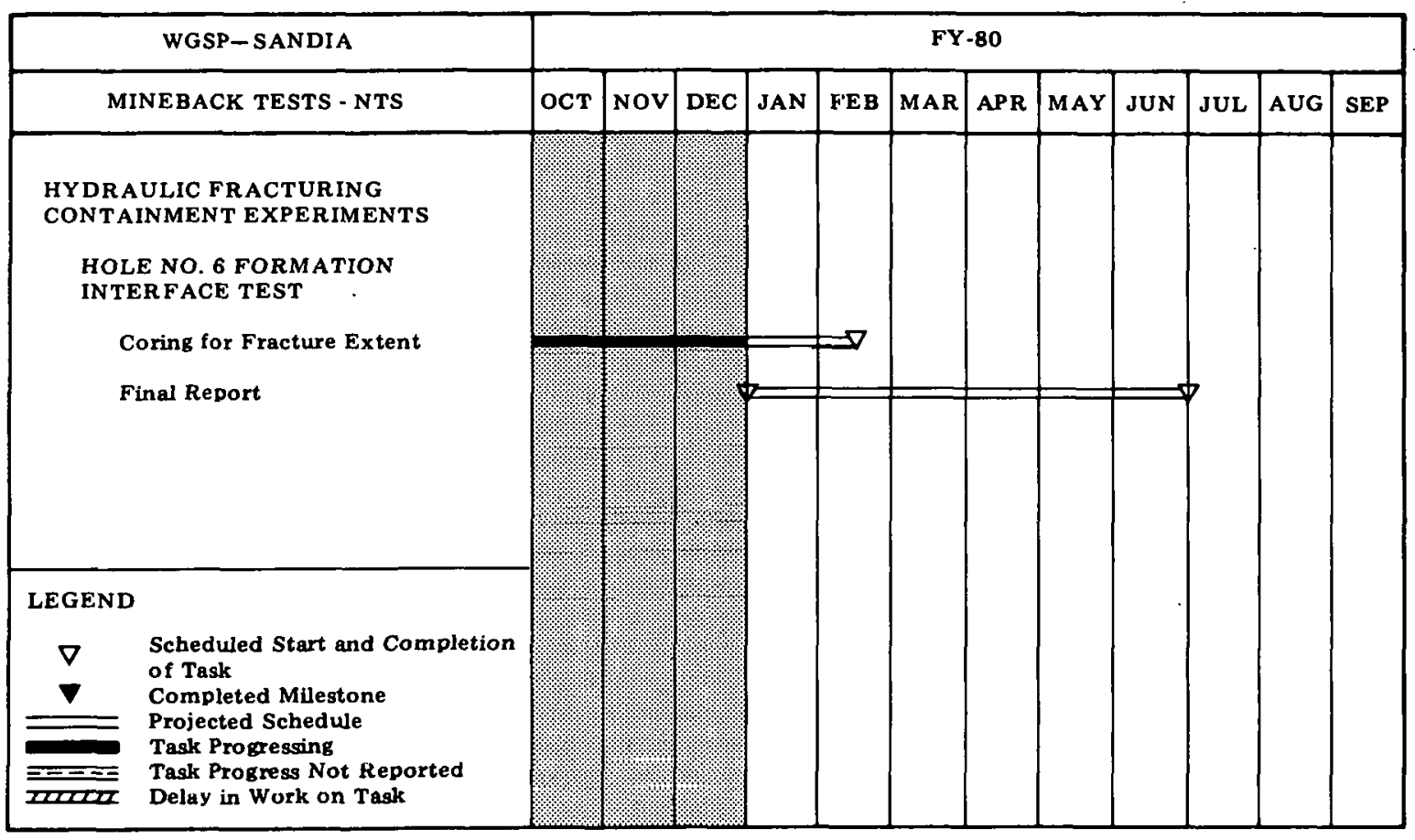

\begin{tabular}{|c|c|c|c|c|c|c|c|c|c|c|c|c|}
\hline WGSP - SANDIA & \multicolumn{12}{|c|}{ FY $\cdot \mathbf{8 0}$} \\
\hline MINEBACK TESTS - NTS & OCT & NOV & DEC & JAN & FEB & MAR & APR & MAY & JUN & JUL & AUG & SEP \\
\hline \multicolumn{13}{|l|}{ INTERFACE TEST SERIES } \\
\hline \multicolumn{13}{|l|}{ Mineback } \\
\hline \multicolumn{13}{|l|}{ Vertical Stress Distribution } \\
\hline \multicolumn{13}{|l|}{$\begin{array}{l}\text { Final Report: Interface-Stress } \\
\text { Effects on Fracturing }\end{array}$} \\
\hline \multicolumn{13}{|l|}{ Rock Mechanics } \\
\hline \multicolumn{13}{|l|}{ Fluid Mechanics } \\
\hline & & & & & & & & & & & & \\
\hline Geology & 1 & & एक & & & & & & - & & & \\
\hline \multicolumn{13}{|l|}{ PROPPANT/FLUID EXPERIMENTS } \\
\hline \multicolumn{13}{|l|}{ Pump System Construction } \\
\hline \multicolumn{13}{|l|}{ Initial System Tests } \\
\hline \multicolumn{13}{|l|}{ Fracture Conductivity Test Series } \\
\hline GEOCHEMISTRY AND PETROLOGY & & & & & & & & & & & & \\
\hline STUDIES & & & & & & & & & & & & \\
\hline
\end{tabular}

Figure 5-11 Milestone Chart-Sandia Mineback 
